\title{
Engineering Disulfide Cross-Links in RNA Via Air Oxidation
}

This unit describes methods for the synthesis of thiol-modified ribonucleosides, their incorporation into synthetic RNA, and the formation of intramolecular disulfide bonds in RNA by air oxidation. The disulfide bonds can be formed in quantitative yields between thiols positioned in close proximity in either RNA secondary or tertiary structure. Disulfide cross-links are useful tools to probe solution structures of RNA, monitor dynamic motions, and stabilize folded RNAs.

Several steps are involved in the successful formation of a disulfide-cross-linked RNA. First, a location for incorporation of the disulfide bond is selected (Glick, 1998). For best results, this should be based on the highest-resolution structural data available for the particular RNA. In most cases, it is desirable to avoid interfering with interactions that stabilize structure, such as hydrogen bonding. Once the site for the disulfide bond has been chosen, the necessary thiol-modified nucleosides must be chemically synthesized. In most cases, the authors use alkylthiol linkers on the $2^{\prime}$ hydroxyl and the $N^{3}$ position of pyrimidine residues, although linkers can be positioned at nearly any position of a nucleoside. The thiol-modified nucleoside phosphoramidites are synthesized with the thiol functionality protected as a tert-butyl disulfide, a protecting group that is stable under all conditions of solid-phase synthesis and subsequent manipulations.

Incorporation of the thiol-modified nucleosides is accomplished by solid-phase chemical synthesis of the RNA. Following removal of both the exocyclic amine-protecting groups and the tert-butyldimethyl silyl groups used to protect the $2^{\prime}$ hydroxyls, the full-length oligoribonucleotide is purified by denaturing polyacrylamide gel electrophoresis (PAGE). Reduction of the mixed disulfide with dithiothreitol (DTT) liberates the free thiols. These are then oxidized by vigorous stirring in air to form an intramolecular disulfide bond in quantitative yield.

The Basic Protocol describes the procedures for formation of intramolecular disulfide bonds by air oxidation of thiol-mediated RNA. Optimized protocols for solid-phase synthesis and deprotection of tRNAs (tRNA is used here as a model RNA) containing thiol-modified residues are presented in Support Protocol 1. Support Protocol 2 describes a method for purification of tRNAs containing thiol-modified residues. Support Protocol 3 describes a fluorescence assay to quantify the concentration of free thiol remaining during cross-link formation. Support Protocols 4, 7, and 8 describe the synthesis of three different thiol-containing nucleoside phosphoramidites, while Support Protocol 6 describes the synthesis of an intermediate compound needed for Support Protocols 7 and 8. Support Protocol 5 details the preparation of a thiol-modified controlled-pore glass (CPG) support used in the solid-phase synthesis of the modified RNA.

NOTE: All procedures should be conducted using sterile techniques. When handling the RNA, suitable precautions should be taken to avoid RNase contamination. Gloves must be worn during handling of all equipment. Treatment of solutions with DEPC to inactivate RNases is not necessary, but could be done if preferred.

CAUTION: Acrylamide is a neurotoxin, minimize inhalation and skin exposure. The reagents and solvents used in both solid-phase RNA synthesis and the synthesis of the thiol-modified phosphoramidites should be handled according to the manufacturer's safety data sheet for each reagent.

Contributed by Emily J. Maglott and Gary D. Glick

Current Protocols in Nucleic Acid Chemistry (2000) 5.4.1-5.4.34

Copyright $(\subseteq 2000$ by John Wiley \& Sons, Inc.
Methods for

Cross-Linking Nucleic Acids 
The RNA used in this protocol has been synthesized with the thiol groups protected as tert-butyl disulfides. Liberation of the free thiols is achieved by reduction of the mixed disulfides with DTT or other reducing agents, such as glutathione. Following removal of the DTT by continuous flow dialysis, the intramolecular disulfide bond is formed in the dilute RNA solution by air oxidation in a mildly basic solution (e.g., $\mathrm{pH}$ 8.0).

\section{Materials}

tert-Butyl-disulfide-modified RNA (see Support Protocol 1)

$100 \mathrm{mM}$ sodium phosphate buffer, $\mathrm{pH} 8.3$ (see recipe)

Dithiothreitol (DTT)

Sodium phosphate buffer/ $\mathrm{NaCl}, \mathrm{pH} 7.0$ (see recipe)

5000-molecular-weight-cutoff (MWCO) cellulose ester membrane

$200 \mathrm{mM} \mathrm{MgCl}$ (see recipe)

$0.1 \mathrm{~N} \mathrm{NaOH}$

TE buffer (APPENDIX 2A)

$1.5 \mathrm{M}$ sodium acetate $(\mathrm{NaOAc}), \mathrm{pH} 5.5$

Absolute ethanol

10-well $(500 \mu \mathrm{L})$ microdialyzer (e.g., Spectrum)

$0.2-\mu \mathrm{m}$ bottle-top filter

Argon (Ar) tank

Peristaltic pump

$70^{\circ} \mathrm{C}$ water bath

$\mathrm{pH}$ meter with microelectrode

Additional reagents and equipment for denaturing polyacrylamide gel electrophoresis (e.g., CPMB UNIT 7.6 and APPENDIX $3 B$ of this manual) or for derivatization and fluorescence spectroscopy for quantitation of thiols (see Support Protocol 3)

\section{Remove tert-butyl disulfide protecting groups to liberate free thiols}

1. In a $0.5-\mathrm{mL}$ microcentrifuge tube, dissolve the tert-butyl-disulfide-modified RNA $\left(0.5 \mathrm{OD}_{260} \mathrm{U}\right)$ to a concentration of $50 \mu \mathrm{M}$ in $16 \mu \mathrm{L}$ of $100 \mathrm{mM}$ sodium phosphate buffer, $\mathrm{pH} 8.3$.

2. Add $0.054 \mathrm{mg}$ DTT (200 eq per disulfide), close the tube, and incubate the mixture at $25^{\circ} \mathrm{C}$ for $12 \mathrm{hr}$.

The authors have found that between 12 and $14 \mathrm{hr}$ of incubation effects complete reduction of the tert-butyl disulfide protecting groups. This can be conveniently conducted overnight.

3. Open the tube and dilute the reaction mixture with $100 \mu \mathrm{L}$ sodium phosphate buffer/ $\mathrm{NaCl}, \mathrm{pH} 7.0$.

4. Assemble a 10-well continuous-flow microdialyzer with a 5000-MWCO cellulose ester membrane following the manufacturer's instructions.

Other types of dialysis assemblies should work as well.

5. Filter $3 \mathrm{~L}$ sodium phosphate buffer/ $\mathrm{NaCl}$ through a $0.2-\mu \mathrm{m}$ bottle-top filter and sparge the filtered buffer with Ar for $\geq 30$ min before use.

6. Fill the dialysis chamber with sodium phosphate buffer $/ \mathrm{NaCl}$, removing all air bubbles from under the wells by forcing them out one of the flow ports as the chamber fills. 
7. Transfer the reduced RNA to a well of the microdialyzer and rinse the reaction tube with phosphate buffer $/ \mathrm{NaCl}$, adding the rinsings to the dialyzer well. Dialyze the RNA against the same buffer at a flow rate of $5.0 \mathrm{~mL} / \mathrm{min}$ for $10 \mathrm{hr}$ at room temperature.

Control experiments show that this method completely removes the DTT.

8. Transfer the dialyzed RNA sample from the dialyzer well to a $1.5-\mathrm{mL}$ microcentrifuge tube. Rinse the well of the dialyzer with 100 to $200 \mu \mathrm{L}$ of sodium phosphate buffer/ $\mathrm{NaCl}$ and add to the RNA sample.

\section{Form intramolecular disulfide bonds via air oxidation}

9. Dilute the reduced, dialyzed tRNA sample to a final RNA concentration of 1 to $4 \mu \mathrm{M}$ with sodium phosphate buffer $/ \mathrm{NaCl}$ to prevent intermolecular disulfide bonds from forming.

10. Add $200 \mathrm{mM} \mathrm{MgCl} 2$ stock solution to $5 \mathrm{mM}$ final concentration. Fold the RNA by heating the RNA sample to $70^{\circ} \mathrm{C}$ for $2 \mathrm{~min}$ in a water bath and then allowing the sample to cool to room temperature (15 to $30 \mathrm{~min}$ ).

This procedure has been optimized for yeast $t R N A^{\text {Phe }}$ samples; details of the folding protocol (i.e., time and temperature for refolding, with $\mathrm{Mg}^{2+}$ concentration) will be different for other RNAs.

11. Calibrate a microelectrode at $\mathrm{pH}$ 7.0. Immerse the electrode in the RNA sample. Adjust the $\mathrm{pH}$ of the sample to 8.0 with $0.1 \mathrm{~N} \mathrm{NaOH}$ (typically 3 to $5 \mu \mathrm{L}$ for a $400-\mu \mathrm{L}$ sample).

12. Stir the RNA solution at room temperature exposed to air, loosely covering the tubes with a paper towel to minimize dust contamination.

13. Monitor disulfide bond formation by removing $5-\mu \mathrm{L}$ aliquots of the reaction mixture and assessing them either by denaturing PAGE (e.g., CPMB UNIT 7.6) or by fluorescence spectroscopy after derivatization with 7-diethylamino-3-(4'-maleimidylphenyl)-4methylcoumarin (see Support Protocol 3). Disulfide bond formation is usually complete in $\leq 12 \mathrm{hr}$.

Progress of cross-linking can be monitored throughout; however frequent monitoring is time-consuming and will decrease final yields.

Cross-linked RNAs have slower gel mobility than the non-cross-linked RNAs (Sigurdsson and Eckstein, 1996).

The fluorescence assay using 7-diethylamino-3-(4'-maleimidylphenyl)-4-methylcoumarin (Parvari et al., 1983) is more sensitive than with Ellman's reagent.

14. Conduct native gel electrophoresis (e.g., СРMB UNIT 2.7) to verify formation of intramolecular cross-links.

15. Dialyze the cross-linked RNA against 1 L TE buffer using continuous-flow microdialysis as described in steps 4 to 8 .

Do not precipitate directly from the phosphate buffer, as recovered yields will be poor.

Disulfide cross-link formation is usually quantitative, as judged by ethidium bromide staining of a sample analyzed by PAGE, and purification to remove non-cross-linked RNA is not necessary.

Methods for Cross-Linking Nucleic Acids 
SUPPORT PROTOCOL 1

\section{Purify RNA from eluate}

16. Add $1 / 5$ vol of $1.5 \mathrm{M} \mathrm{NaOAc}, \mathrm{pH} 5.5$, and $3 \mathrm{vol}$ absolute ethanol. Mix thoroughly and place at $-20^{\circ} \mathrm{C}$ overnight.

17. Centrifuge $1 \mathrm{hr}$ at $16,000 \times g, 4^{\circ} \mathrm{C}$.

18. Decant the solution and dry the pellet of RNA under vacuum.

19. Combine the RNA into one tube by dissolving the pellets in water and transferring to one tube. Rinse the tubes at least 3 times with water to ensure transfer of all RNA. Evaporate the RNA solutions dryness under vacuum and store at $-20^{\circ} \mathrm{C}$ until use.

20. Store the precipitated RNA at $-20^{\circ} \mathrm{C}$ (stable at least 1 year).

\section{SYNTHESIS OF RNA CONTAINING tert-BUTYLDISULFIDE-MODIFIED NUCLEOSIDES BY SOLID-PHASE METHODS}

Incorporation of modified nucleosides into an RNA can be accomplished with the necessary phosphoramidites and solid-phase synthesis technology. The following procedure has been optimized to use standard, commercially available ribonucleoside phosphoramidites and reagents combined with thiol-modified nucleoside phosphoramidites to allow total chemical synthesis of RNAs at least 76 nucleotides long. Careful handling to minimize exposure of the phosphoramidites and reagents to moisture throughout the procedure enables milligram quantities of 76-mer RNAs containing modified nucleosides to be obtained from a single $1-\mu \mathrm{mol}$-scale synthesis.

\section{Materials}

Methylene chloride $\left(\mathrm{CH}_{2} \mathrm{Cl}_{2}\right)$ in $\mathrm{CaH}_{2}$ Acetonitrile $\left(\mathrm{CH}_{3} \mathrm{CN}\right)$ in $\mathrm{CaH}_{2}$ Thiol-modified nucleoside phosphoramidites (see Support Protocols 4, 7, and 8)

Nucleoside phosphoramidites

Argon (Ar)

Anhydrous ethanol

Absolute ethanol, room temperature and $-20^{\circ} \mathrm{C}$

Brine (saturated aqueous $\mathrm{NaCl}$ )

Nitrogen $\left(\mathrm{N}_{2}\right)$ stream

Ammonia gas $\left(\mathrm{NH}_{3}\right)$

1.0 M tetrabutylammonium fluoride (TBAF) in tetrahydrofuran (THF)

$1.5 \mathrm{M}$ sodium acetate $(\mathrm{NaOAc}), \mathrm{pH} 5.5$ (see recipe)

Ethyl acetate (EtOAc)

Rotoevaporator

Automated nucleic acid synthesizer

Trap-Pak molecular sieve bags (Perseptive Biosystems)

Rubber septa

Cannula

CPG column loaded with appropriate nucleoside (purchased, or see Support

Protocol 5)

Desiccator

1- and 2-dram glass vials (oven dried $>8 \mathrm{hr}$ at $180^{\circ} \mathrm{C}$ )

Teflon tape

Dry bath, $55^{\circ} \mathrm{C}$

Speedvac evaporator or equivalent

Spatula, RNase-free 
5-in. (12.5-cm) glass pipets

Rotary shaker

Prepare thiol-modified phosphoramidites for automated synthesis

1. At least $24 \mathrm{hr}$ before beginning the RNA synthesis, distill $1 \mathrm{~L} \mathrm{CH}_{2} \mathrm{Cl}_{2}$ and $100 \mathrm{~mL}$ $\mathrm{CH}_{3} \mathrm{CN}$ from $\mathrm{CaH}_{2}$.

2. Dry the necessary thiol-modified phosphoramidites by coevaporation with distilled $\mathrm{CH}_{3} \mathrm{CN}(\sim 1 \mathrm{~mL} / 50 \mathrm{mg})$ three times, then under high vacuum overnight.

The quantity of phosphoramidite depends on both the RNA sequence (if the same or different nucleosides are used) and the number of sequences being synthesized at one time. One coupling typically takes $5 \mathrm{mg}$ dissolved in $5 \mathrm{~mL}$ on a Perkin-Elmer Expedite 8909 synthesizer.

3. Prepare the automated nucleic acid synthesizer for RNA synthesis following the manufacturer's suggested protocols.

Replacing all reagent solutions on the synthesizer with newly opened bottles of reagents immediately prior to use significantly improves both the quality and the yield of the synthesis. Although commercial preparations of 3\% TCA can be used, it is recommended that solutions of $3 \% \mathrm{TCA}$ be made with freshly distilled $\mathrm{CH}_{2} \mathrm{Cl}_{2}$ immediately prior to synthesis. The use of Trap-Pak molecular sieve bags to remove residual water in the solvent in $\mathrm{CH}_{3} \mathrm{CN}$ solutions (one Trap-Pak per liter) is also recommended.

The protocols described here have been conducted with both $A^{N-B z}, C^{N-B z}, G^{N-i B u}$, and $U$ 5'-O-dimethoxytrityl, 2'-O-tert-butyldimethylsilyl, 3'-O-diisopropyl- $\beta$-cyanoethyl phosphoramidites as well as $A^{N-P a c}$ and $G^{N-P a c} 5^{\prime}$-O-dimethoxytrityl, $2^{\prime}$-O-tert-butyldimethylsilyl, and 3'-O-diisopropyl- $\beta$-cyanoethyl phosphoramidites. Other exocyclic amine-protecting groups should also be suitable for these protocols.

4. Backfill the flask(s) containing the thiol-modified phosphoramidite(s) with Ar and quickly seal with a rubber septum.

5. Working under Ar, dilute the thiol-modified phosphoramidite(s) with distilled $\mathrm{CH}_{3} \mathrm{CN}$ to $50 \mathrm{mg} / \mathrm{mL}$. Using a cannula, place the solution into an oven-dried bottle of appropriate size for the synthesizer and place on the synthesizer.

This amidite concentration is recommended for an Expedite 8909 synthesizer (Perseptive Biosystems). Other synthesizers will also work; amidites should be diluted according to the manufacturer's protocols.

6. Prime the delivery lines with all ancillary reagents twice, and then prime the delivery lines with the amidite solutions twice, to ensure that the flow lines from each bottle of reagent and from the amidite bottle are filled.

7. Place a CPG column loaded with the appropriate nucleoside onto the synthesizer.

See Glick (1991) for details on the loading of thiol-modified supports.

8. Begin the RNA synthesis following the manufacturer's protocols.

Addition of $\mathrm{CH}_{2} \mathrm{Cl}_{2}$ wash steps both before and after TCA treatment improves coupling efficiencies (see Goodwin et al., 1996).

RNA synthesis is very sensitive to water. Eliminate water from all reagents and handling procedures as much as possible. The use of freshly distilled $\mathrm{CH}_{3} \mathrm{CN}$ and $\mathrm{CH}_{2} \mathrm{Cl}_{2}$ and newly opened dry reagents improves coupling efficiencies and allows the synthesis of RNAs exceeding 75 residues. It is also recommended that phosphoramidites be handled under an Ar atmosphere in a glove bag, especially in humid conditions. While solutions of $A, C$, and $U$ phosphoramidites are stable for at least 5 days, the coupling efficiency of $G$ phosphoramidites is increased with fresh dilution on a daily basis. A typical RNA coupling cycle

Methods for Cross-Linking Nucleic Acids 
takes 15 min (Gait et al., 1991; Goodwin et al., 1994). The synthesis of one 76-mer tRNA sequence takes $\sim 19.5 \mathrm{hr}$.

\section{Deprotect synthetic RNA}

9. Cool a 2-dram oven-dried vial under $\mathrm{N}_{2}$.

10. Add 2 to $3 \mathrm{~mL}$ anhydrous ethanol to the vial and cool in a brine/ice water bath under $\mathrm{N}_{2}$ for 2 to $5 \mathrm{~min}$.

11. Remove the $\mathrm{N}_{2}$ line and insert a needle attached to a lecture bottle of $\mathrm{NH}_{3}$ and a vent. Saturate the ethanol by constant bubbling with $\mathrm{NH}_{3}$ for at least $30 \mathrm{~min}$.

This procedure should be conducted in a fume hood.

12. Open the synthesis column and pour the solid support into a 1-dram oven-dried vial.

13. Quickly pour $\sim 1 \mathrm{~mL}$ of the anhydrous ethanolic ammonia solution into the vial. Seal threads of the vial with Teflon tape and cap tightly. Seal the outside of the cap with Teflon tape and parafilm to prevent evaporation.

The inner Teflon tape can be put on the vial before pouring the solution, but be careful not to pour the ethanolic ammonia onto the tape or the seal will not be adequate. Usually bubbling occurs as the solution is poured onto the resin.

14. Place the sealed vial in a $55^{\circ} \mathrm{C}$ dry bath for $18 \mathrm{hr}$.

15. Remove the vial from the dry bath and allow to cool to room temperature before opening. Carefully open the vial and pass a gentle stream of $\mathrm{N}_{2}$ over the solution for 5 to 15 min to remove the ammonia.

When the cap is removed, there should be a small release of pressure; this indicates that the ethanolic ammonia solution was thoroughly saturated during deprotection.

A significant portion of the ethanol may evaporate during this procedure. If the solution becomes viscous (typically, with less than $\sim 300 \mu \mathrm{L}$ ethanol remaining), add $500 \mu \mathrm{L}$ of anhydrous ethanol to the vial before proceeding to step 16.

16. Transfer the ethanol solution from the vial to an autoclaved $1.5-\mathrm{mL}$ microcentrifuge tube and evaporate under vacuum to $\leq 400 \mu \mathrm{L}$ total volume. Transfer any remaining solution to the microcentrifuge tube and then rinse the solid support with $500 \mu \mathrm{L}$ anhydrous ethanol. Add the rinsing to the microcentrifuge tube and evaporate the solution under vacuum to $\leq 400 \mu \mathrm{L}$.

17. Thoroughly rinse the solid support with anhydrous ethanol five more times using 100 to $200 \mu \mathrm{L}$ ethanol each time, adding the rinsings to the microcentrifuge tube. Evaporate the solution to dryness under vacuum. Coevaporate with $500 \mu \mathrm{L}$ anhydrous ethanol. Repeat the coevaporation once more using $200 \mu \mathrm{L}$ ethanol.

The residue resulting from step 17 may be stored for a few days at $-20^{\circ} \mathrm{C}$ before proceeding with the remainder of this protocol.

\section{Desilylate synthetic RNA}

18. Cool a 1-dram oven-dried vial in a desiccator.

19. Gently loosen the residue obtained after step 17 from the microcentrifuge tube with the tip of an RNase-free spatula. Carefully transfer the residue to the dried vial.

20. Add $\sim 400 \mu \mathrm{L}$ of $1.0 \mathrm{M}$ TBAF in THF to the microcentrifuge tube with a glass pipet. Vortex, centrifuge, and transfer the solution to the vial with a glass pipet. Repeat this rinsing procedure twice more using $\sim 300 \mu \mathrm{L}$ TBAF each time. 
TBAF solutions should be of the highest purity and lowest water content possible. For optimal results, bottles of TBAF should only be used once. TBAF is light sensitive.

21. Seal the vial with Teflon tape, parafilm, and cover in foil. Place the vial on a rotary shaker and shake at low speed for $24 \mathrm{hr}$.

22. Open the vial and quench the reaction with $1 \mathrm{~mL}$ of $1.5 \mathrm{M} \mathrm{NaOAc}, \mathrm{pH}$ 5.5. Transfer the solution in two approximately equal aliquots into two $1.5-\mathrm{mL}$ microcentrifuge tubes. Rinse the vial 5 times with $150 \mu \mathrm{L}$ water and add the rinsings to the tubes.

23. Evaporate the solutions to $\sim 600 \mu \mathrm{L}$ total volume in each tube. Add 600 to $700 \mu \mathrm{L}$ EtOAc to each tube and homogenize as thoroughly as possible. Centrifuge to separate the layers. Remove the upper layer (EtOAc) with a pipet and repeat the extraction a second time. Evaporate the solution under vacuum for $\sim 10 \mathrm{~min}$ to remove residual EtOAc.

24. Transfer about half of the solution in each tube to another 1.5-mL microcentrifuge tube, resulting in four tubes containing $\sim 300 \mu \mathrm{L}$ solution each.

25. Add $1 \mathrm{~mL}$ absolute ethanol to each tube, mix thoroughly, and place at $-20^{\circ} \mathrm{C}$ overnight.

26. Centrifuge all tubes for at least $1 \mathrm{hr}$ at $16,000 \times g, 4^{\circ} \mathrm{C}$. Decant the supernatant from the pellet and then wash the pellet with $200 \mu \mathrm{L}$ of $-20^{\circ} \mathrm{C}$ absolute ethanol. Dry the pellet under vacuum.

27. Quantify the crude RNA by dissolving the pellets in water and measuring the absorbance of a $1-\mu \mathrm{L}$ aliquot of the solution at $260 \mathrm{~nm}$. Estimate the molar extinction coefficient $\left(\varepsilon_{260}\right)$ using nearest-neighbor calculations.

The $\varepsilon_{260}$ calculation is done as described by Breslauer et al. (1986); see UNIT 7.3. This assumes that the modified residues behave like their unmodified counterparts.

Both crude and purified RNA samples should be stored either pelleted from ethanol precipitation or dried down from aqueous solutions at $-20^{\circ} \mathrm{C}$.

28. Purify the crude RNA to single-nucleotide resolution (see Support Protocol 2).

\section{PURIFICATION OF SYNTHETIC RNA CONTAINING tert-BUTYLDISULFIDE PROTECTED THIOL-MODIFIED NUCLEOSIDES}

Single-nucleotide resolution of the products resulting from solid-phase synthesis, the fulllength oligomer as well as failed sequences, can be achieved using denaturing PAGE (also see APPENDIX $3 B$ ). The procedures that are outlined have been optimized for the purification of a 76-mer tRNA sequence. These protocols can be modified for sequences of other lengths by adjusting the percentage of acrylamide in the gel matrix until both the full-length RNA and the sequence resulting from incomplete synthesis one residue from the end are resolved.

\section{Materials}

Crude synthetic tRNA (see Support Protocol 1)

$80 \%$ formamide containing $0.05 \%$ xylene cyanol (XC) tracking dye

$8 \%$ denaturing polyacrylamide solution (see recipe)

$1 \times$ TBE electrophoresis buffer (APPENDIX 2A)

$1 \times$ and $4 \times$ TAE electrophoresis buffer (APPENDIX 2A)

$1.5 \mathrm{M}$ sodium acetate $(\mathrm{NaOAc}), \mathrm{pH} 5.5$

Absolute ethanol

Power supply

Silica-gel plate

Methods for Cross-Linking Nucleic Acids 
UVG-11 Mineralight lamp (254 nm, $115 \mathrm{~V}$ ) or equivalent

Razor blade, RNase free

Hoefer Six-Pac electroeluter or equivalent

Inner elution tubes

Porous polyethylene plugs

Blotter-paper discs

Additional reagents and equipment for denaturing polyacrylamide gel

electrophoresis (e.g., see CPMB UNIT 7.6 and APPENDIX $3 B$ of this manual)

\section{Separate RNA species by PAGE}

1. Dissolve 20 to $40 \mathrm{OD}_{260} \mathrm{U}$ of crude synthetic tRNA in $60 \mu \mathrm{L}$ water, mix thoroughly, and allow to stand for $\sim 1 \mathrm{hr}$ to thoroughly dissolve the RNA.

There will probably also be insoluble material present.

2. Add $60 \mu \mathrm{L}$ of $80 \%$ formamide $/ 0.05 \% \mathrm{XC}$ and centrifuge briefly to separate the insoluble matter.

3. Prepare an $8 \%$ denaturing polyacrylamide gel $31.0 \mathrm{~cm} \times 38.5 \mathrm{~cm} \times 0.8 \mathrm{~mm}$, with 14.6-mm-wide wells (e.g., see CPMB UNIT 7.6 and APPENDIX $3 B$ ).

Electrophoresis conditions are outlined for the purification of a 76-nt tRNA sequence. For sequences of different lengths, adjust the percentage acrylamide and electrophoresis time accordingly.

4. Load $20 \mu \mathrm{L}$ of the RNA sample into each of six wells, being careful not to load any insoluble material onto the gel.

5. Electrophorese the gel in $1 \times \mathrm{TBE}$ at $55 \mathrm{~W}$ until the $\mathrm{XC}$ tracking dye has migrated $\sim 11$ inches ( $\sim 4$ to $4.5 \mathrm{hr})$.

Under these conditions 76-mer RNA migrates with the XC-be careful not to run the RNA off the gel.

\section{Electroelute full-length synthetic RNA from gel slice}

6. Place the gel over a silica-gel plate in a dark location. Briefly shine 254-nm light on the gel to locate the RNA. With a clean RNase-free razor blade, excise the full-length RNA from the gel.

RNA is photoreactive; minimize exposure of RNA to UV light.

7. Pack the RNA slices into three or four inner elution tubes containing $300 \mu \mathrm{L}$ of $1 \times$ TAE using blotter-paper discs and porous polyethylene plugs according to manufacturer's directions. Cut off the bottom tip of the inner elution tube and insert into a 1.5 -mL microcentrifuge tube containing $200 \mu \mathrm{L}$ of $4 \times$ TAE. Electroelute in a Hoefer Six-Pac eluter for $90 \mathrm{~min}$ at $+50 \mathrm{~V}$.

For efficient electroelution, remove all air bubbles from the inner elution tubes. Also, the elutions work better if the inner elution tubes are packed tightly with gel slices, but it is important not to crush the slices. If the amperage does not decrease below $0.2 \mathrm{~mA}$ during the course of electroelution, the gel slices can be recovered from the inner elution tube and soaked in $400 \mu \mathrm{L}$ of $4 \times T A E$ at room temperature overnight. The eluted RNA should then be ethanol precipitated as described in the next step and combined with the RNA eluted during electroelution.

Engineering

Disulfide

Cross-Links in

RNA via Air Oxidation

8. Remove the inner elution tube carefully, rinse the electrode with $20 \mu \mathrm{L}$ water, and add to the eluted RNA. Remove the electrode and pipet all buffer remaining above the porous plug into the eluted RNA.

The total volume should be $\sim 350 \mu \mathrm{L}$. 
9. Add $70 \mu \mathrm{L}$ of $1.5 \mathrm{M} \mathrm{NaOAc}, \mathrm{pH} 5.5$, and $1 \mathrm{~mL}$ absolute ethanol. Mix thoroughly and place at $-20^{\circ} \mathrm{C}$ overnight.

10. Centrifuge $1 \mathrm{hr}$ at $16,000 \times g, 4^{\circ} \mathrm{C}$.

11. Decant the solution and dry the pellet of RNA under vacuum.

12. Combine the RNA into one tube by dissolving the pellets in water and transferring to one tube. Rinse the tubes at least 3 times with water to ensure transfer of all RNA. Evaporate the RNA solutions dryness under vacuum and store at $-20^{\circ} \mathrm{C}$ until use (stable at least 1 year).

\section{QUANTIFICATION OF THIOLS IN RNA USING 7-DIETHYLAMINO-3-(4'-MALEIMIDYLPHENYL)-4-METHYLCOUMARIN}

Reaction of free thiols with 7-diethylamino-3-(4'-maleimidylphenyl)-4-methylcoumarin produces a fluorescent adduct that can be quantified spectroscopically (Parvari et al., 1983). This provides a convenient method to determine when the cross-linking reaction is complete. The method can be used to accurately determine thiol concentrations as low as $0.5 \mu \mathrm{M}$.

\section{Materials}

RNA solution containing free thiols (see Basic Protocol)

$5 \times$ CPM buffer (see recipe)

$0.4 \mathrm{mM}$ CPM in isopropyl alcohol (see recipe)

$1 \%$ Triton $\mathrm{X}-100$

Sodium phosphate buffer/ $\mathrm{NaCl}, \mathrm{pH} 7.0$ (see recipe)

Fluorimeter and cuvette

1. To a $5-\mu \mathrm{L}$ aliquot of an RNA solution containing free thiols, add $1 \mu \mathrm{L}$ of $5 \times \mathrm{CPM}$ buffer and $5 \mu \mathrm{L}$ of $0.4 \mathrm{mM} \mathrm{CPM}$ in isopropyl alcohol. Incubate the sample $10 \mathrm{~min}$ at room temperature.

2. Dilute the reaction with $489 \mu \mathrm{L}$ of $1 \%$ Triton $\mathrm{X}-100$.

3. Prepare a blank consisting of:

$5 \mu \mathrm{L}$ sodium phosphate buffer $/ \mathrm{NaCl}, \mathrm{pH} 7.0$

$1 \mu \mathrm{L} 5 \times$ CPM buffer

$5 \mu \mathrm{L} 0.4 \mathrm{mM}$ CPM in isopropyl alcohol $489 \mu \mathrm{L}$ Triton $\mathrm{X}-100$.

4. Transfer blank solution to a fluorimeter cuvette and measure the fluorescence intensity at $480 \mathrm{~nm}\left(\lambda_{\mathrm{ex}}=390 \mathrm{~nm}\right)$.

5. In the same way, measure the fluorescence intensity of the RNA solution from step 2 , and correcting for background fluorescence.

A calibration curve can be constructed using DTT as a standard (0.5 to $5 \mathrm{mM}$ is a useful range). 

$\beta$-CYANOETHYLPHOSPHORAMIDITE) tert-BUTYL DISULFIDE (S.5)

The preparation of a thiol-containing nucleoside phosphoramidite modified at the $N^{3}$ position of uridine is described. The synthesis of 5'-O-(4,4'-dimethoxytrityl)-2'-O-(tertbutyldimethylsilyl)- $N^{3}$-(ethyl)uridine-3'-O-(N,N-diisopropyl- $\beta$-cyanoethylphosphoram idite) tert-butyl disulfide (S.5) proceeds in four sets of steps from uridine (Fig. 5.4.1). The 3'-O-tert-butyldimethylsilyl-protected isomer (S.4) obtained as a side product of the third set of steps is used to make a thiol-modified controlled-pore glass (CPG) support (Fig. 5.4.2; see Support Protocol 5).

\section{Materials}

Uridine

Distilled acetonitrile $\left(\mathrm{CH}_{3} \mathrm{CN}\right)$

Distilled triethylamine $\left(\mathrm{Et}_{3} \mathrm{~N}\right)$

$N, N$-Dimethylformamide (DMF)

Chlorotrimethylsilane (TMSCl)

$\mathrm{N}_{2}$

Petroleum ether

Diethyl ether $\left(\mathrm{Et}_{2} \mathrm{O}\right)$

Sodium hydride $(\mathrm{NaH})$

1-Tosyl-2-benzoylmercaptoethanol (see Glick et al., 1991)

$48 \%(w / v)$ aqueous $\mathrm{HF}$

Methylene chloride $\left(\mathrm{CH}_{2} \mathrm{Cl}_{2}\right)$

Brine (saturated aqueous $\mathrm{NaCl}$ )

Sodium sulfate $\left(\mathrm{Na}_{2} \mathrm{SO}_{4}\right)$

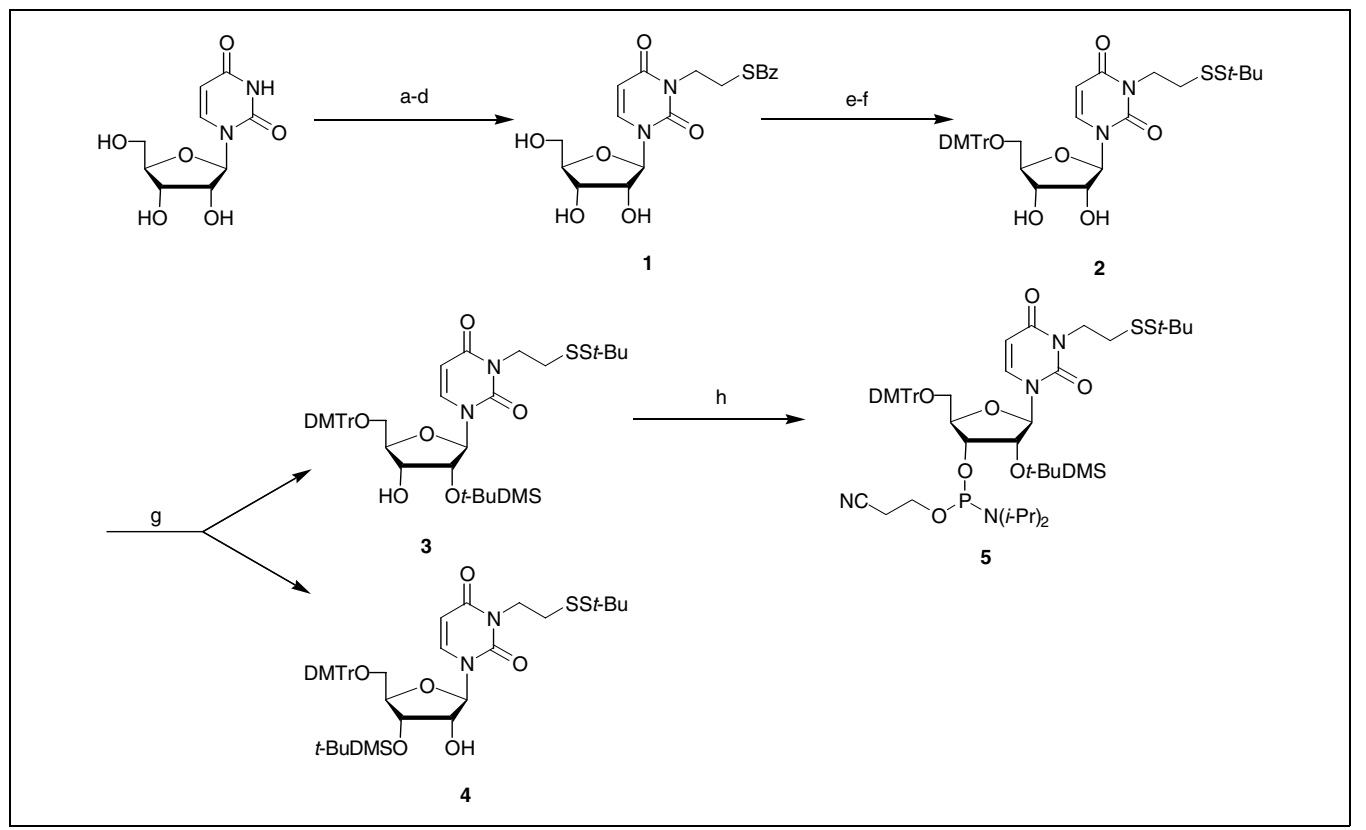

Figure 5.4.1 Synthesis of $5^{\prime}-O-\left(4,4^{\prime}\right.$-dimethoxytrityl)-2'-O-(tert-butyldimethylsilyl)- $N^{3}$-(ethyl)uridine-3'-O-(N,N-diisopropyl- $\beta$-cyanoethylphosphoramidite) tert-butyl disulfide. (a) TMSCl, Et 3 N, DMF;

Engineering Disulfide Cross-Links in RNA via Air Oxidation (b) $\mathrm{NaH}$, DMF; (c) p-TsOCH${ }_{2} \mathrm{CH}_{2} \mathrm{SBz}$, DMF; (d) HF (aq); (e) DMTrCl, pyridine; (f) 1-(tert-butylthio)1,2-hydrazinedicarboxmorpholide, $\mathrm{LiOH}, \mathrm{CH}_{3} \mathrm{OH}$; (g) TBDMSCl, imidazole, DMF; (h) chloro- $N, N$ diisopropylamine- $\beta$-cyanoethyl phosphine, 2,4,6-collidine, $N$-methylimidazole, THF. Abbreviations: $\mathrm{Bz}$, benzoyl; DMF, dimethylformamide; DMTr, 4,4'-dimethoxytrityl; TBDMS, tert-butyldimethylsilyl; THF, tetrahydrofuran; Ts, tosyl. 


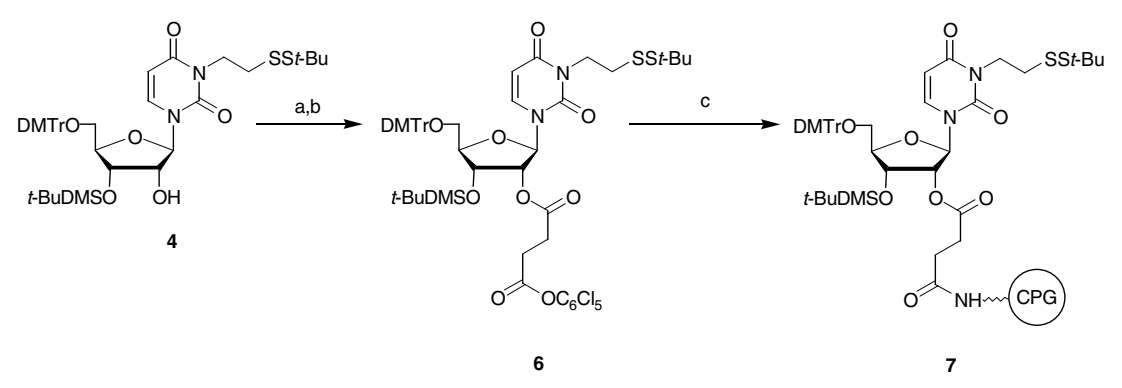

Figure 5.4.2 Synthesis of 5'-O-(4,4'-dimethoxytrityl)-3'-O-(tert-butyldimethylsilyl)-2'-O-succinylCPG $N^{3}$-(ethyl)uridine tert-butyl disulfide. (a) succinic anhydride, DMAP, pyridine; (b) pentachlorophenol, DCC, DMAP, $\mathrm{CH}_{2} \mathrm{Cl}_{2}$; (c) CPG (1000 Å), Et $3 \mathrm{~N}$, DMF. Abbreviations: DCC, dicyclohexyl-carbodiimide; DMAP, 4-dimethylaminopyridine; DMF, dimethylformamide; DMSO, dimethyl sulfoxide.

\author{
Methanol $\left(\mathrm{CH}_{3} \mathrm{OH}\right)$ \\ Pyridine \\ 4,4'-Dimethoxytrityl chloride (DMTrCl) \\ 1-(tert-Butylthio)-1,2-hydrazine carboxmorpholide (see Wünsch et al., 1982) \\ $\mathrm{LiOH} \cdot \mathrm{H}_{2} \mathrm{O}$ \\ Ethyl acetate (EtOAc) \\ Imidazole \\ tert-Butyldimethylsilyl chloride (TBDMSCl) \\ Tetrahydrofuran (THF) \\ 2,4,6-Collidine \\ $N$-Methylimidazole \\ Chloro- $N, N$-diisopropylamine- $\beta$-cyanoethyl phosphine \\ Additional reagents and equipment for flash chromatography (APPENDIX 3E)
}

\title{
Prepare $N^{3}$-(2-thiobenzoylethyl)uridine (S.1)
}

1. Dry $24.42 \mathrm{~g}$ uridine $(100 \mathrm{mmol})$ by coevaporation with distilled $\mathrm{CH}_{3} \mathrm{CN}$.

2. Dissolve the dried uridine in $83.6 \mathrm{~mL}$ freshly distilled $\mathrm{Et}_{3} \mathrm{~N}(600 \mathrm{mmol}, 6 \mathrm{eq})$ and $250 \mathrm{~mL}$ DMF.

3. Cool the solution to $4^{\circ} \mathrm{C}$.

4. Slowly add $42 \mathrm{~mL}$ chlorotrimethylsilane $(330 \mathrm{mmol}, 3.3 \mathrm{eq})$ and stir the reaction under $\mathrm{N}_{2}$ for $2 \mathrm{hr}$.

5. Remove salts that precipitate during the course of the reaction by filtration under $\mathrm{N}_{2}$.

6. Triturate the residual salts in the filtrate with $1: 1(\mathrm{v} / \mathrm{v})$ petroleum ether/diethyl ether.

7. Dissolve the residue in $400 \mathrm{~mL}$ DMF and cool to $4^{\circ} \mathrm{C}$.

8. Add $4.40 \mathrm{~g} \mathrm{NaH}$ (110 mmol, $1.1 \mathrm{eq})$ to the reaction mixture with stirring under $\mathrm{N}_{2}$.

9. After hydrogen evolution subsides, add $37 \mathrm{~g}$ 1-tosyl-2-benzoylmercaptoethanol (110 mmol, $1.1 \mathrm{eq}$ ) and stir the reaction overnight at $45^{\circ} \mathrm{C}$.

This step is based on the procedure detailed by Glick (1991).

10. Cool the solution to room temperature and remove the silyl groups by the addition of $5 \mathrm{~mL}$ of $48 \%$ aqueous $\mathrm{HF}$. 
11. After $1 \mathrm{hr}$, dilute the reaction mixture with $\mathrm{CH}_{2} \mathrm{Cl}_{2}$ and wash successively with water and brine.

12. Dry the organic layer over $\mathrm{Na}_{2} \mathrm{SO}_{4}$ and concentrate under vacuum.

13. Purify the oily residue by flash chromatography (APPENDIX $3 E$ ) using 19:1 (v/v) $\mathrm{CH}_{2} \mathrm{Cl}_{2} / \mathrm{CH}_{3} \mathrm{OH}$ to obtain $\mathbf{S . 1}$ as a white foam (26 g, 63\% yield).

Prepare $5^{\prime}$-O-(4,4'-dimethoxytrityl)- $N^{3}$-(ethyl)uridine tert-butyl disulfide (S.2)

14. Coevaporate $15.0 \mathrm{~g}$ compound $\mathbf{S . 1}(37 \mathrm{mmol})$ once from $100 \mathrm{~mL}$ of 9:1 (v/v) $\mathrm{CH}_{3} \mathrm{CN} /$ pyridine, then dissolve in $185 \mathrm{~mL}$ pyridine.

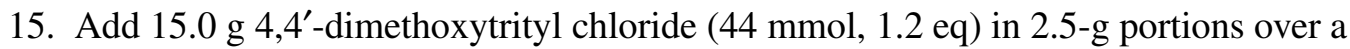
6-hr period at $4{ }^{\circ} \mathrm{C}$ with stirring.

16. Allow the reaction to warm to room temperature overnight while stirring under $\mathrm{N}_{2}$.

17. Add $5 \mathrm{~mL} \mathrm{CH}_{3} \mathrm{OH}$ and stir the mixture an additional $10 \mathrm{~min}$.

18. Remove the solvents under vacuum, and coevaporate the residue with $100 \mathrm{~mL} \mathrm{CH}_{3} \mathrm{CN}$ to yield a light yellow-orange foam.

19. Dissolve the crude tritylated product (14 g, $20 \mathrm{mmol})$ in $100 \mathrm{~mL} \mathrm{CH}_{3} \mathrm{OH}$ and add $8.31 \mathrm{~g}$ 1-(tert-butylthio)-1,2-hydrazinedicarboxmorpholide (Wünsch et al., 1982) (24 $\mathrm{mmol}, 1.2 \mathrm{eq})$ and $2.52 \mathrm{~g} \mathrm{LiOH} \cdot \mathrm{H}_{2} \mathrm{O}(60 \mathrm{mmol}, 3.0 \mathrm{eq})$.

20. Stir the reaction under $\mathrm{N}_{2}$ for $12 \mathrm{hr}$ and then concentrate the mixture under vacuum.

21. Dissolve the residue in EtOAc and wash with brine.

22. Dry the organic layer over $\mathrm{Na}_{2} \mathrm{SO}_{4}$ and concentrate under vacuum.

23. Purify the residue by flash chromatography (APPENDIX $3 E$ ) using a step gradient of $3: 2$ to 2:3 (v/v) petroleum ether/EtOAc to obtain $\mathbf{S . 2}$ as a white foam $(9.7 \mathrm{~g}, 70 \%$ yield $)$.

Prepare 5'-O-(4,4'-dimethoxytrityl)-2'-O-(tert-butyldimethylsilyl)- $\mathrm{N}^{3}$-(ethyl)uridine tert-butyl disulfide (S.3) and 5'-O-(4,4'-dimethoxytrityl)-3'-O-(tert-butyldimethylsilyl)- $N^{3}$-(ethyl)uridine tert-butyl disulfide (S.4)

24. Dissolve $9.5 \mathrm{~g}$ compound $\mathbf{S . 2}(13.6 \mathrm{mmol})$ in $50 \mathrm{~mL}$ DMF.

25. Add $2.31 \mathrm{~g}$ imidazole ( $34 \mathrm{mmol}, 2.5 \mathrm{eq}$ ) and $2.58 \mathrm{~g}$ tert-butyldimethylsilyl chloride (17.1 mmol, $1.25 \mathrm{eq})$.

26. Stir the mixture overnight under $\mathrm{N}_{2}$.

27. Dilute the reaction with EtOAc, wash the mixture with brine, dry over $\mathrm{Na}_{2} \mathrm{SO}_{4}$, and evaporate under vacuum.

28. Purify the residue by flash chromatography (APPENDIX 3E) using 9:1 (v/v) petroleum ether/EtOAc to obtain S.3 and S.4 as white foams (S.3: $3.9 \mathrm{~g}, 40 \%$ yield; S.4: $2.1 \mathrm{~g}$, $25 \%$ yield).

Prepare 5'-O-(4,4'-dimethoxytrityl)-2'-O-(tert-butyldimethylsilyl)- $\mathrm{N}^{3}$-(ethyl)uridine-

Engineering

Disulfide

Cross-Links in

RNA via Air

Oxidation
3'-O-(N,N-diisopropyl- $\beta$-cyanoethylphosphoramidite) tert-butyl disulfide (S.5)

29. Dissolve $0.81 \mathrm{~g}$ compound $\mathbf{S . 3}(1.0 \mathrm{mmol})$ in $3.0 \mathrm{~mL}$ THF.

30. Add $1.0 \mathrm{~mL} 2,4,6$-collidine $(7.5 \mathrm{mmol}, 7.5 \mathrm{eq})$ and $40 \mu \mathrm{L} N$-methylimidazole $(0.5$ $\mathrm{mmol}, 0.5 \mathrm{eq})$. 
31. Add $0.56 \mathrm{~mL}$ chloro- $N, N$-diisopropylamine- $\beta$-cyanoethyl phosphine ( $2.5 \mathrm{mmol}, 2.5$ eq) dropwise while stirring under $\mathrm{N}_{2}$.

32. After $2 \mathrm{hr}$, dilute the reaction with EtOAc and wash the mixture with $\mathrm{NaHCO}_{3}$ and brine.

33. Dry the organic layer over $\mathrm{Na}_{2} \mathrm{SO}_{4}$, and concentrate under vacuum.

34. Purify the residue by flash chromatography (APPENDIX $3 E$ ) using 80:15:5 (v/v/v) petroleum ether/EtOAc/Et ${ }_{3} \mathrm{~N}$ to obtain $\mathbf{S . 5}$ as a brittle white foam $(0.82 \mathrm{~g}, 82 \%$ yield $)$.

SYNTHESIS OF 5'-O-(4,4'-DIMETHOXYTRITYL)-3'-O-(tert-BUTYLDIMETHYLSILYL)-2'-O-SUCCINYL-CPG $N^{3}$-(ETHYL)URIDINE tert-BUTYL DISULFIDE CONTROLLED-PORE GLASS SUPPORT

$5^{\prime}$-O-(4,4'-dimethoxytrityl)-3'-O-(tert-butyldimethylsilyl)-2'-O-succinyl-CPG $N^{3}$-(ethyl)uridine tert-butyl disulfide (Fig. 5.4.2), a thiol-modified controlled-pore glass (CPG) support, is prepared using a side product (S.4) obtained in Support Protocol 4. This nucleoside support can be used to introduce a thiol modification at the $3^{\prime}$ terminus of an RNA species. The nucleoside loading concentration is usually $32 \mu \mathrm{mol} / \mathrm{g}$ (Schaller et al., 1963).

\section{Materials}

Compound S.4 (see Support Protocol 4)

Pyridine

Succinic anhydride

4-Dimethylaminopyridine (DMAP)

Methylene chloride $\left(\mathrm{CH}_{2} \mathrm{Cl}_{2}\right)$

Brine (saturated aqueous $\mathrm{NaCl}$ )

Sodium sulfate $\left(\mathrm{Na}_{2} \mathrm{SO}_{4}\right)$

Pentachlorophenol

Dicyclohexylcarbodiimide (DCC)

Petroleum ether

Ethyl acetate (EtOAc)

Long-chain alkyl amino controlled-pore glass (CPG), 1000-Å pore size, $100 \mu \mathrm{mol}$ amino groups/g, 120/200 mesh

$N, N$-Dimethylformamide (DMF)

Triethylamine $\left(\mathrm{Et}_{3} \mathrm{~N}\right)$

Methanol $\left(\mathrm{CH}_{3} \mathrm{OH}\right)$

Diethyl ether $\left(\mathrm{Et}_{2} \mathrm{O}\right)$

Acetic anhydride

Additional reagents and equipment for flash chromatography (APPENDIX $3 E$ )

Prepare 5'-O-(4,4'-dimethoxytrityl)-3'-O-(tert-butyldimethylsilyl)-2'-O-pentachlorophenylsuccinate $N^{3}$-(ethyl)uridine tert-butyl disulfide (S.6)

1. Dissolve $1.77 \mathrm{~g}$ compound $\mathbf{S . 4}(2.2 \mathrm{mmol})$ in $12.0 \mathrm{~mL}$ pyridine under $\mathrm{N}_{2}$.

2. Add $0.69 \mathrm{~g}$ succinic anhydride $(6.6 \mathrm{mmol}, 3.0 \mathrm{eq})$ and $0.133 \mathrm{~g}$ DMAP (1.1 mmol, 0.5 eq) and incubate $12 \mathrm{hr}$.

3. Concentrate the reaction mixture under vacuum.

4. Dissolve the residue in $\mathrm{CH}_{2} \mathrm{Cl}_{2}$ and wash with brine.

5. Dry the organic layer over $\mathrm{Na}_{2} \mathrm{SO}_{4}$ and concentrate under vacuum.

Methods for Cross-Linking Nucleic Acids 
6. Dissolve the crude succinate in $25 \mathrm{~mL} \mathrm{CH}_{2} \mathrm{Cl}_{2}$ and add $0.88 \mathrm{~g}$ pentachlorophenol (3.3 mmol, $1.5 \mathrm{eq}), 67 \mathrm{mg}$ DMAP (0.55 mmol, $0.25 \mathrm{eq})$, and $0.91 \mathrm{~g} \mathrm{DCC}$ (4.4 mmol, 2.0 eq).

7. After $8 \mathrm{hr}$, add petroleum ether to precipitate dicyclohexylurea.

8. Gravity filter the reaction mixture and concentrate under vacuum.

9. Purify the residue by flash chromatography (APPENDIX $3 E)$ using 4:1 (v/v) petroleum ether/EtOAc to obtain S.6 as a white foam (2.3 g, 90\% yield).

\section{Prepare 5'-O-(4,4'-dimethoxytrityl)-3'-O-(tert-butyldimethylsilyl)-2'-O-succinyl-CPG} $N^{3}$-(ethyl)uridine tert-butyl disulfide (S.7)

10. Suspend long-chain alkyl amino CPG in $4.0 \mathrm{~mL}$ DMF with $0.58 \mathrm{~g}$ compound $\mathbf{S . 6}$ $(0.5 \mathrm{mmol}, 5 \mathrm{eq})$ and $0.14 \mathrm{~mL} \mathrm{Et}_{3} \mathrm{~N}(1.0 \mathrm{mmol}, 10 \mathrm{eq})$.

11. Gently swirl the mixture in the dark for 2 days.

12. Vacuum filter the support and rinse successively with $15 \mathrm{~mL} \mathrm{DMF}, 50 \mathrm{~mL} \mathrm{CH}_{3} \mathrm{OH}$, and $50 \mathrm{~mL} \mathrm{Et}_{2} \mathrm{O}$.

13. Remove the residual solvents under vacuum.

14. Acetylate the unreacted amino groups by swirling the support for $1 \mathrm{hr}$ with $0.70 \mathrm{~mL}$ acetic anhydride (7.0 mmol, 100 eq) and $10 \mathrm{mg}$ DMAP $(70 \mu \mathrm{mol}, 1 \mathrm{eq})$ in $4 \mathrm{~mL}$ pyridine.

15. Rinse the support successively with $30 \mathrm{~mL}$ pyridine, $90 \mathrm{~mL} \mathrm{CH}_{3} \mathrm{OH}$, and $90 \mathrm{~mL} \mathrm{Et}_{2} \mathrm{O}$.

16. Remove the residual solvents under vacuum.

SUPPORT PROTOCOL 6

Engineering

Disulfide

Cross-Links in

RNA via Air Oxidation

\section{SYNTHESIS OF 3',5'-O-(TETRAISOPROPYLDISILOXANE-1,3-DIYL)-2' $O$ - ALLYL- ${ }^{4}$-(2-NITROPHENYL) URIDINE (S.10) INTERMEDIATE}

Preparation of thiol-modified nucleoside phosphoramidite modified at the $2^{\prime}$-hydroxyl position of pyrimidines proceeds from preparation of $3^{\prime}, 5^{\prime}-O$-(tetraisopropyldisiloxane1,3-diyl)-2'-O-allyl- $O^{4}$-(2-nitrophenyl)uridine. Preparation of this compound is described. First, uridine is converted to $3^{\prime}, 5^{\prime}-O$-(tetraisopropyldisiloxane-1,3-diyl)$O^{4}$-(2-nitrophenyl) uridine (S.9) in two sets of steps as described by Sproat and Lamond (1991). This compound is then allylated using the procedure described by Sproat et al. (1991).

\section{Materials}

Uridine

Pyridine

1,3-Dichloro-1,1,3,3-tetraisopropyldisiloxane

Methylene chloride $\left(\mathrm{CH}_{2} \mathrm{Cl}_{2}\right)$

Methanol $\left(\mathrm{CH}_{3} \mathrm{OH}\right)$

Saturated aqueous sodium bicarbonate $\left(\mathrm{NaHCO}_{3}\right)$

Sodium sulfate $\left(\mathrm{Na}_{2} \mathrm{SO}_{4}\right)$

Triethylamine $\left(\mathrm{Et}_{3} \mathrm{~N}\right)$

Chlorotrimethylsilane

Brine (saturated aqueous $\mathrm{NaCl}$ )

2-Mesitylenesulfonyl chloride

4-Dimethylaminopyridine (DMAP)

2-Nitrophenol

1,4-Diazabicyclo[2.2.2] octane (DABCO) 
$p$-Toluenesulfonic acid monohydrate

$p$-Dioxane

Ethyl acetate (EtOAc)

Petroleum ether

Tetrahydrofuran (THF)

Triphenylphosphine

Tris(dibenzylideneacetone) dipalladium $(0)$

Allyl ethyl carbonate

Additional reagents and equipment for flash chromatography (APPENDIX 3E)

Prepare 3',5'-O-(tetraisopropyldisiloxane-1,3-diyl)-uridine (S.8)

1. Dissolve $499 \mathrm{mg}$ uridine $(2.04 \mathrm{mmol})$ in $5.1 \mathrm{~mL}$ pyridine.

2. Cool to $0^{\circ} \mathrm{C}$ under $\mathrm{N}_{2}$.

3. Dissolve $732 \mu \mathrm{L}$ 1,3-dichloro-1,1,3,3-tetraisopropyldisiloxane (2.29 mmol, $1.1 \mathrm{eq}$ ) in $0.5 \mathrm{~mL} \mathrm{CH}_{2} \mathrm{Cl}_{2}$ and add dropwise to uridine solution.

4. Stir the reaction, allowing it to warm to room temperature, for $4 \mathrm{hr}$.

5. Dilute the reaction by adding $0.4 \mathrm{~mL} \mathrm{CH}_{3} \mathrm{OH}$, and evaporate under vacuum.

6. Dissolve the residue in $15 \mathrm{~mL} \mathrm{CH}_{2} \mathrm{Cl}_{2}$ and wash three times with saturated aqueous $\mathrm{NaHCO}_{3}$.

7. Dry the organic layer over $\mathrm{Na}_{2} \mathrm{SO}_{4}$ and evaporate under vacuum.

8. Dissolve the residue in toluene and evaporate under vacuum to obtain $\mathbf{S . 8}$ as a white foam $(1.0 \mathrm{~g}, 100 \%)$.

Prepare 3',5'-O-(tetraisopropyldisiloxane-1,3-diyl)- $\mathrm{O}^{4}$-(2-nitrophenyl) uridine (S.9)

9. Dissolve $3.4 \mathrm{~g}$ compound $\mathbf{S . 8}(6.9 \mathrm{mmol})$ in $35 \mathrm{~mL} \mathrm{CH}_{2} \mathrm{Cl}_{2}$ and cool to $0^{\circ} \mathrm{C}$.

It may be necessary to repeat the synthesis of $\mathbf{S . 8}$ to obtain the necessary quantity for the synthesis of S.9.

10. Add $9 \mathrm{~mL} \mathrm{Et}_{3} \mathrm{~N}$ ( $\left.64.6 \mathrm{mmol}, 9.4 \mathrm{eq}\right)$ followed by $6.4 \mathrm{~mL}$ chlorotrimethylsilane $(50.4$ mmol, 7.3 eq) and stir the reaction $4 \mathrm{hr}$ under $\mathrm{N}_{2}$.

11. Pour the reaction onto $100 \mathrm{~mL}$ saturated aqueous $\mathrm{NaHCO}_{3}$ and stir for $10 \mathrm{~min}$.

12. Wash the organic layer with brine, dry over $\mathrm{Na}_{2} \mathrm{SO}_{4}$, and concentrate under vacuum to a peach foam $(3.8 \mathrm{~g}, 100 \%)$.

13. Dissolve the residue in $36 \mathrm{~mL} \mathrm{CH}_{2} \mathrm{Cl}_{2}$ and $4.8 \mathrm{~mL} \mathrm{Et}_{3} \mathrm{~N}$ (34.6 mmol, $5 \mathrm{eq}$ ).

14. Add $2.25 \mathrm{~g}$ 2-mesitylenesulfonyl chloride (10.3 mmol, $1.5 \mathrm{eq})$ and $0.5 \mathrm{~g}$ DMAP (3.5 mmol, 0.5 eq). Stir for $15 \mathrm{~min}$.

15. Add $2.0 \mathrm{~g}$ 2-nitrophenol (14.4 mmol, $2.1 \mathrm{eq})$ and $0.42 \mathrm{~g}$ DABCO (3.7 mmol, 0.55 eq) and continue stirring for $3 \mathrm{hr}$.

16. Dilute the reaction with $40 \mathrm{~mL} \mathrm{CH}_{2} \mathrm{Cl}_{2}$ and wash with saturated aqueous $\mathrm{NaHCO}_{3}$.

17. Backwash the aqueous layer twice with $\mathrm{CH}_{2} \mathrm{Cl}_{2}$.

18. Dry the combined organic layers over $\mathrm{Na}_{2} \mathrm{SO}_{4}$ and concentrate under vacuum.

19. Dissolve the residue in $21 \mathrm{~mL} \mathrm{CH}_{2} \mathrm{Cl}_{2}$ and add a solution of $2.70 \mathrm{~g} p$-toluenesulfonic acid monohydrate in $21 \mathrm{~mL} p$-dioxane. 
20. Stir the reaction for $2 \mathrm{~min}$ and then quench by adding $2.5 \mathrm{~mL} \mathrm{Et}_{3} \mathrm{~N}$.

21. Pour the reaction onto saturated aqueous $\mathrm{NaHCO}_{3}$ and backwash the aqueous layer with $\mathrm{CH}_{2} \mathrm{Cl}_{2}$ twice.

22. Dry the combined organic layers over $\mathrm{Na}_{2} \mathrm{SO}_{4}$ and concentrate under vacuum.

23. Purify the residue by flash chromatography (APPENDIX $3 E$ ) using $55 \%$ EtOAc in petroleum ether to obtain $\mathbf{S . 9}(4.5 \mathrm{~g}, 6.9 \mathrm{mmol}, 100 \%)$.

\section{Prepare 3',5'-O-(tetraisopropyldisiloxane-1,3-diyl)-2'-O-allyl-O $\mathrm{O}^{4}$-(2-nitrophenyl)} uridine (S.10)

24. Dissolve the $4.5 \mathrm{~g}$ compound $\mathbf{S . 9}$ in $37 \mathrm{~mL}$ THF (37 mL).

25. Add $371 \mathrm{mg}$ triphenylphosphine $(1.4 \mathrm{mmol}, 0.2 \mathrm{eq})$ and $168 \mathrm{mg}$ tris(dibenzylideneacetone) dipalladium(0) $(0.2 \mathrm{mmol}, 0.026 \mathrm{eq})$.

26. Add $1.9 \mathrm{~mL}$ allyl ethyl carbonate ( $14.0 \mathrm{mmol}, 2 \mathrm{eq})$ dropwise.

27. Heat the reaction to reflux for $2 \mathrm{hr}$.

28. Cool the reaction to room temperature and concentrate under vacuum.

29. Purify the residue by flash chromatography (APPENDIX $3 E$ ) using $18 \%$ EtOAc in petroleum ether to obtain $\mathbf{S . 1 0}$ (3.3 g, 72\%).

SUPPORT PROTOCOL 7

Engineering Disulfide Cross-Links in RNA via Air Oxidation

\section{SYNTHESIS OF $5^{\prime}-O-\left(4,4^{\prime}\right.$-DIMETHOXYTRITYL)- $N^{4}$-(BENZOYL)- $2^{\prime}-O$ - (ETHYL)CYTIDINE-3' $O$-( $N$, $N$-DIISOPROPYL- $\beta$-CYANOETHYLPHOS- PHORAMIDITE) tert-BUTYL DISULFIDE (S.20)}

The intermediate prepared in Support Protocol 6 is converted to $3^{\prime}, 5^{\prime}-O$-(tetraisopropyldisiloxane-1,3-diyl)- $N^{4}$-(benzoyl)-2'-O-allyl cytidine (S.11) using the method of Sproat and Lamond (1991) replacing isobutyryl chloride with benzoyl chloride. The synthesis of the fully protected phosphoramidite can be accomplished in nine sets of steps (Fig. 5.4.3).

\section{Materials}

Compound S.10 (see Support Protocol 6)

Tetrahydrofuran (THF)

Ammonia $\left(\mathrm{NH}_{3}\right)$

$\mathrm{N}_{2}$

Methanol $\left(\mathrm{CH}_{3} \mathrm{OH}\right)$

Petroleum ether

Ethyl acetate (EtOAc)

Pyridine

$N, N$-Dimethylformamide (DMF)

Benzoic anhydride

Ammonium hydroxide $\left(\mathrm{NH}_{4} \mathrm{OH}\right)$

$\mathrm{N}$-Methylmorpholine- $\mathrm{N}$-oxide

Acetone

Osmium tetroxide $\left(\mathrm{OsO}_{4}\right)$

Saturated aqueous sodium bisulfite

Diethyl ether $\left(\mathrm{Et}_{2} \mathrm{O}\right)$

Saturated aqueous sodium bicarbonate $\left(\mathrm{NaHCO}_{3}\right)$

Brine (saturated aqueous $\mathrm{NaCl}$ )

Sodium sulfate $\left(\mathrm{Na}_{2} \mathrm{SO}_{4}\right)$ 


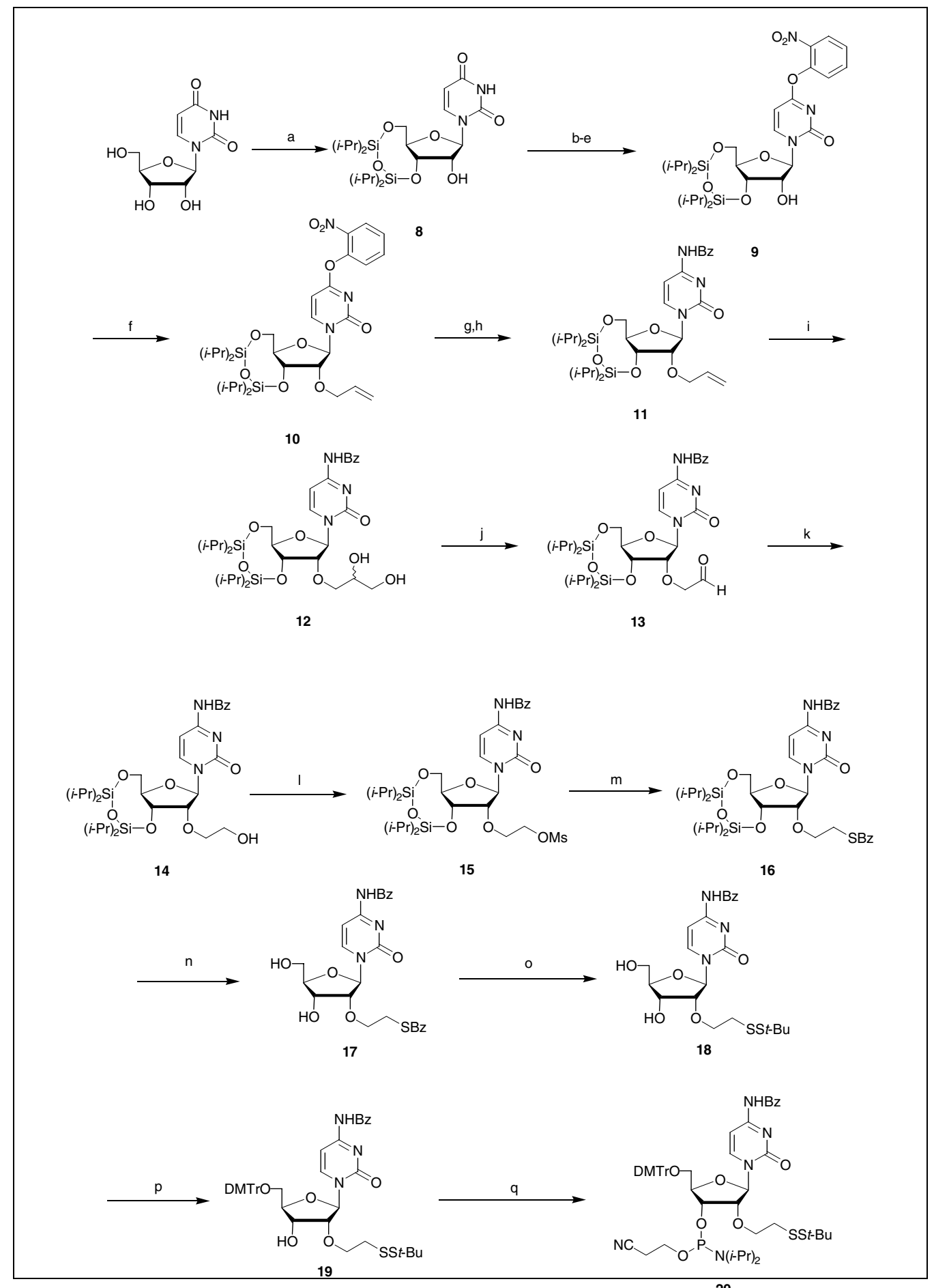

20

Figure 5.4.3 Synthesis of $5^{\prime}-O-\left(4,4^{\prime}\right.$-dimethoxytrityl)- $N^{4}$-(benzoyl)-2'-O-(ethyl)cytidine tert-butyl disulfide $3^{\prime}-O$-( $N, N$-diisopropyl- $\beta$-cyanoethylphosphoramidite). (a) pyridine, 1,3-dichloro-1,1,3,3tetraisopropyldisiloxane, $\mathrm{CH}_{2} \mathrm{Cl}_{2}$; (b) chlorotrimethylsilane, $\mathrm{Et}_{3} \mathrm{~N}_{2} \mathrm{CH}_{2} \mathrm{Cl}_{2}$; (c) 2-mesitylenesulfonyl chloride, DMAP, $\mathrm{Et}_{3} \mathrm{~N}, \mathrm{CH}_{2} \mathrm{Cl}_{2}$; (d) 2-nitrophenol, DABCO; (e) $p$-toluenesulfonic acid monohydrate, p-dioxane, $\mathrm{CH}_{2} \mathrm{Cl}_{2}$; (f) triphenylphosphine, tris(dibenzylideneacetone) dipalladium(0), allyl ethyl carbonate, THF; (g) $\mathrm{NH}_{3}$, THF; (h) pyridine, benzoic anhydride, DMF; (i) $\mathrm{OsO}_{4}, \mathrm{~N}$-methylmorpholine- $\mathrm{N}$-oxide, acetone, $\mathrm{H}_{2} \mathrm{O}$; (j) $\mathrm{NalO}_{4}$, p-dioxane, $\mathrm{H}_{2} \mathrm{O}$; (k) $\mathrm{NaBH}_{4}, \mathrm{CH}_{3} \mathrm{OH}$; (I) methanesulfonyl chloride, pyridine; (m) thiobenzoic acid, Et $3 \mathrm{~N}$, DMF; (n) HF (aq), $\mathrm{CH}_{3} \mathrm{CN}$; (o) 1-(tert-butylthio)-1,2hydrazinedicarboxmorpholide, $\mathrm{LiOH}, \mathrm{CH}_{3} \mathrm{OH}$, THF; (p) DMTrCl, Et ${ }_{3} \mathrm{~N}$, DMF, DMAP; (q) chloro- $N, N-$ diisopropylamine- $\beta$-cyanoethyl phosphine, $\mathrm{N}, \mathrm{N}$-diisopropylethylamine, $\mathrm{CH}_{2} \mathrm{Cl}_{2}$. Abbreviations: $\mathrm{Bz}$, benzoyl; DMAP, 4-dimethylaminopyridine; DMF, dimethylformamide; DMTr, 4,4'-dimethoxytrityl; Ms, methanesulfonyl; THF, tetrahydrofuran.

Methods for Cross-Linking Nucleic Acids 
Methylene chloride $\left(\mathrm{CH}_{2} \mathrm{Cl}_{2}\right)$

$p$-Dioxane

Sodium periodate $\left(\mathrm{NaIO}_{4}\right)$

Sodium borohydrate $\left(\mathrm{NaBH}_{4}\right)$

Methanesulfonyl chloride

Triethylamine $\left(\mathrm{Et}_{3} \mathrm{~N}\right)$

Thiobenzoic acid

Acetonitrile $\left(\mathrm{CH}_{3} \mathrm{CN}\right)$

$48 \%(\mathrm{w} / \mathrm{v})$ aqueous $\mathrm{HF}$

1-(tert-Butylthio)-1,2-hydrazinedicarboxmorpholide (Wünsch et al., 1982)

$\mathrm{LiOH} \cdot \mathrm{H}_{2} \mathrm{O}$

$1 \mathrm{~N}$ aqueous sodium citrate

4-Dimethylaminopyridine (DMAP)

4,4'-Dimethoxytrityl chloride (DMTrCl)

$N, N$-Diisopropylethylamine

Chloro- $N, N$-diisopropylamine- $\beta$-cyanoethyl phosphine

Pressure tube $\left(-78^{\circ} \mathrm{C}\right)$

$\mathrm{CO}_{2}$ /isopropyl alcohol ( $i$-PrOH) bath

Additional reagents and equipment for flash chromatography (APPENDIX 3E)

Prepare 3',5'-O-(tetraisopropyldisiloxane-1,3-diyl)- $N^{4}$-(benzoyl)-2'-O-allyl cytidine

(S.11)

1. Dissolve $1.94 \mathrm{~g}$ compound $\mathbf{S . 1 0}(2.99 \mathrm{mmol})$ in $8.5 \mathrm{~mL}$ THF in a pressure tube.

2. Cool the tube to $-78^{\circ} \mathrm{C}$ using a $\mathrm{CO}_{2} / i-\mathrm{PrOH}$ bath.

3. Add $5 \mathrm{~g} \mathrm{NH}_{3}$ (299 mmol, $\left.100 \mathrm{eq}\right)$.

4. Seal the reaction vessel and stir while allowing it to warm to room temperature for $62 \mathrm{hr}$.

5. Cool the reaction mixture to $-78^{\circ} \mathrm{C}$ using $\mathrm{CO}_{2} / i-\mathrm{PrOH}$ bath and open the pressure tube.

6. Allow the mixture to warm under $\mathrm{N}_{2}$ to room temperature.

7. Concentrate under vacuum.

8. Purify the residue by flash chromatography (APPENDIX $3 E$ ) using a step gradient of 0 to $10 \% \mathrm{CH}_{3} \mathrm{OH}$ in $7: 3(\mathrm{v} / \mathrm{v})$ petroleum ether/EtOAc.

9. Dissolve the purified residue in $14 \mathrm{~mL}$ pyridine and $6.5 \mathrm{~mL}$ DMF.

10. Add $0.72 \mathrm{~g}$ benzoic anhydride $(3.20 \mathrm{mmol}, 1.5 \mathrm{eq})$ and stir the reaction under $\mathrm{N}_{2}$ for $12 \mathrm{hr}$ at room temperature.

11. Cool the reaction to $0^{\circ} \mathrm{C}$ and add $0.4 \mathrm{~mL}$ water.

12. Stir the reaction $5 \mathrm{~min}$ at $0^{\circ} \mathrm{C}$, then add $0.3 \mathrm{~mL} \mathrm{NH}_{4} \mathrm{OH}$.

Engineering

Disulfide

Cross-Links in

RNA via Air

Oxidation

13. Continue stirring the reaction $10 \mathrm{~min}$ at $0^{\circ} \mathrm{C}$, then concentrate the mixture under vacuum.

14. Purify the residue by flash chromatography (APPENDIX $3 E$ ) using $3: 2(\mathrm{v} / \mathrm{v})$ petroleum ether/EtOAc to obtain $\mathbf{S . 1 1}$ (1.42 g, 75\% yield) as a white foam. 
Prepare 3',5'-O-(tetraisopropyldisiloxane-1,3-diyl)- 2'-O-(2,3-dihydroxypropyl)cytidine (S.12)

15. Dissolve $1.34 \mathrm{~g}$ compound $\mathbf{S . 1 1}(2.30 \mathrm{mmol})$ and $0.27 \mathrm{~g} N$-methylmorpholine- $N$-oxide $(2.34 \mathrm{mmol}, 1.1 \mathrm{eq})$ in $21 \mathrm{~mL}$ of $6: 1(\mathrm{v} / \mathrm{v})$ acetone/water.

16. Add $5 \mathrm{mg} \mathrm{OsO}_{4}(21 \mu \mathrm{mol}, 0.01 \mathrm{eq})$ and stir the reaction mixture in the dark for 2.5 hr.

17. Add $1 \mathrm{~mL}$ saturated aqueous sodium bisulfite to precipitate osmium salts.

18. Decant the solution and dissolve the light-brown residue in $\mathrm{Et}_{2} \mathrm{O}$.

19. Wash the solution with saturated aqueous $\mathrm{NaHCO}_{3}$ and brine.

20. Dry the combined organic layers over $\mathrm{Na}_{2} \mathrm{SO}_{4}$ and concentrate under vacuum.

21. Purify the yellow residue by flash chromatography (APPENDIX $3 E$ ) using a step gradient of 19:1 to 37:3 $\mathrm{CH}_{2} \mathrm{Cl}_{2} / \mathrm{CH}_{3} \mathrm{OH}$ to obtain $\mathbf{S . 1 2}$ (1.27 $\mathrm{g}, 90 \%$ yield).

Prepare 3',5'-O-(tetraisopropyldisiloxane-1,3-diyl)-N"-(benzoyl)-2'-O-(ethanal)cytidine (S.13)

22. Dissolve the $1.27 \mathrm{~g}$ compound $\mathbf{S . 1 2}(1.91 \mathrm{mmol})$ in $20 \mathrm{~mL}$ of $3: 1(\mathrm{v} / \mathrm{v}) p$-dioxane/water.

23. Add $0.49 \mathrm{~g} \mathrm{NaIO}_{4}(2.29 \mathrm{mmol}, 1.2 \mathrm{eq})$ and stir the reaction mixture in the dark for $4.5 \mathrm{hr}$.

24. Dilute the reaction with $\mathrm{Et}_{2} \mathrm{O}$ and wash with water.

25. Dry the organic layer over $\mathrm{Na}_{2} \mathrm{SO}_{4}$ and concentrate under vacuum.

26. Purify the residue by flash chromatography (APPENDIX $3 E$ ) using 19:1 (v/v) $\mathrm{CH}_{2} \mathrm{Cl}_{2} / \mathrm{CH}_{3} \mathrm{OH}$ to obtain $\mathbf{S . 1 3}$ as a white foam (2.94 g, 97\% yield).

Prepare 3',5'-O-(tetraisopropyldisiloxane-1,3-diyl)- $N^{4}$-(benzoyl)-2'-O(2-hydroxyethyl)cytidine (S.14)

27. Dissolve $1.17 \mathrm{~g}$ compound $\mathbf{S . 1 3}$ (1.85 mmol) in $19 \mathrm{~mL} \mathrm{CH}_{3} \mathrm{OH}$.

28. Add $21 \mathrm{mg} \mathrm{NaBH} 4(0.56 \mathrm{mmol}, 0.3 \mathrm{eq})$ and stir the mixture in the dark under $\mathrm{N}_{2}$ for $90 \mathrm{~min}$.

29. Dilute the solution with $\mathrm{Et}_{2} \mathrm{O}$ and wash with saturated aqueous $\mathrm{NaHCO}_{3}$ and brine.

30. Wash the aqueous layer once with $\mathrm{Et}_{2} \mathrm{O}$.

31. Dry the combined organic layers over $\mathrm{Na}_{2} \mathrm{SO}_{4}$ and concentrate under vacuum.

32. Purify the residue by flash chromatography (APPENDIX 3E) using 19:1 (v/v) $\mathrm{CH}_{2} \mathrm{Cl}_{2} / \mathrm{CH}_{3} \mathrm{OH}$ to obtain $\mathbf{S . 1 4}$ as a white foam (1.09 g, 93\% yield).

Prepare 3',5'-O-(tetraisopropyldisiloxane-1,3-diyl)- $N^{4}$-(benzoyl)-2'-O-(ethyl-2methylsulfonate)cytidine (S.15)

33. Dissolve the $1.09 \mathrm{~g}$ compound $\mathbf{S . 1 4}(1.72 \mathrm{mmol})$ in $17 \mathrm{~mL} \mathrm{CH}_{2} \mathrm{Cl}_{2}$ and $1.4 \mathrm{~mL}$ pyridine (17.2 $\mathrm{mmol}, 10 \mathrm{eq})$.

34. Cool under $\mathrm{N}_{2}$ to $0^{\circ} \mathrm{C}$.

35. Add $0.19 \mathrm{~mL}$ methanesulfonyl chloride (2.41 mmol, $1.2 \mathrm{eq})$ dropwise.

36. Stir the mixture under $\mathrm{N}_{2}$ while gradually warming to room temperature overnight. 
37. Dilute the reaction with $\mathrm{Et}_{2} \mathrm{O}$ and wash with saturated aqueous $\mathrm{NaHCO}_{3}$ and brine.

38. Dry the organic layer over $\mathrm{Na}_{2} \mathrm{SO}_{4}$ and concentrate under vacuum.

39. Purify the residue by flash chromatography (APPENDIX $3 E$ ) using $24: 1$ (v/v) $\mathrm{CH}_{2} \mathrm{Cl}_{2} / \mathrm{CH}_{3} \mathrm{OH}$ to obtain $\mathbf{S . 1 5}$ as a white foam (1.13 g, 92\% yield).

Prepare 3',5'-O-(tetraisopropyldisiloxane-1,3-diyl)- $N^{4}$-(benzoyl)-2'-O-(thiobenzoylethyl) cytidine (S.16)

40. Dissolve $1.04 \mathrm{~g}$ compound $\mathbf{S . 1 5}$ (1.46 mmol) in $5.8 \mathrm{~mL} \mathrm{DMF.}$

41. Add $2.0 \mathrm{~mL} \mathrm{Et}_{3} \mathrm{~N}$ (14.6 mmol, $\left.10 \mathrm{eq}\right)$ and $0.34 \mathrm{~mL}$ thiobenzoic acid (2.91 mmol, 2.0 eq).

42. Stir the mixture under $\mathrm{N}_{2}$ in the dark overnight.

43. Dilute the solution with $\mathrm{Et}_{2} \mathrm{O}$ and wash with saturated aqueous $\mathrm{NaHCO}_{3}$ and brine.

44. Dry the organic layer over $\mathrm{Na}_{2} \mathrm{SO}_{4}$ and concentrate under vacuum to a dark orangebrown solid.

45. Purify the residue by flash chromatography (APPENDIX $3 E$ ) using a step gradient of 0 to $10 \% \mathrm{CH}_{3} \mathrm{CN}$ in 2:1 (v/v) petroleum ether/EtOAc to obtain $\mathbf{S . 1 6}$ as a white foam (0.84 g, $76 \%$ yield).

Prepare $\mathrm{N}^{4}$-(benzoyl)-2'-O-(thiobenzoylethyl)cytidine (S.17)

46. Dissolve $0.37 \mathrm{~g}$ compound $\mathbf{S . 1 6}(0.49 \mathrm{mmol})$ in $4.3 \mathrm{~mL} \mathrm{CH}_{3} \mathrm{CN}$.

47. Add $0.5 \mathrm{~mL}$ of $48 \%$ aqueous $\mathrm{HF}$ and stir the reaction mixture for $7 \mathrm{hr}$.

48. Dilute the solution with $\mathrm{Et}_{2} \mathrm{O}$ and wash with $\mathrm{H}_{2} \mathrm{O}$.

49. Dry the organic layer over $\mathrm{Na}_{2} \mathrm{SO}_{4}$ and concentrate under vacuum.

50. Purify the pink residue by flash chromatography (APPENDIX $3 E$ ) using 19:1 (v/v) $\mathrm{CH}_{2} \mathrm{Cl}_{2} / \mathrm{CH}_{3} \mathrm{OH}$ to obtain $\mathbf{S . 1 7}$ as a white foam $(0.25 \mathrm{~g}, 100 \%$ yield $)$.

\section{Prepare $\mathrm{N}^{4}$-(benzoyl)-2'-O-(ethyl)cytidine tert-butyl disulfide (S.18)}

51. Dissolve the $0.25 \mathrm{~g}$ compound $\mathbf{S . 1 7}(0.49 \mathrm{mmol})$ in $3.8 \mathrm{~mL}$ of $1: 1(\mathrm{v} / \mathrm{v}) \mathrm{CH}_{3} \mathrm{OH} / \mathrm{THF}$.

52. Add $0.20 \mathrm{~g} \mathrm{1-(tert-butylthio)-1,2-hydrazinedicarboxmorpholide} \mathrm{(Wünsch} \mathrm{et} \mathrm{al.,}$ 1982) (0.58 mmol, $1.2 \mathrm{eq})$ and $41 \mathrm{mg} \mathrm{LiOH} \cdot \mathrm{H}_{2} \mathrm{O}(0.97 \mathrm{mmol}, 2.0 \mathrm{eq})$.

53. Stir the reaction under $\mathrm{N}_{2}$ at $0^{\circ} \mathrm{C}$ for $45 \mathrm{~min}$.

54. Dilute the reaction with EtOAc, and then wash with $1 \mathrm{~N}$ aqueous sodium citrate and the saturated aqueous $\mathrm{NaHCO}_{3}$.

55. Dry the organic layer over $\mathrm{Na}_{2} \mathrm{SO}_{4}$ and concentrate under vacuum.

56. Purify the residue by flash chromatography (APPENDIX $3 E$ ) using 24:1 (v/v) $\mathrm{CH}_{2} \mathrm{Cl}_{2} / \mathrm{CH}_{3} \mathrm{OH}$ to obtain $\mathbf{S . 1 8}$ as a pink foam $(0.18 \mathrm{~g}, 74 \%$ yield $)$.

\section{Prepare 5'-O-(4,4'-dimethoxytrityl)-N $N^{4}$-(benzoyl)-2'-O-(ethyl)cytidine tert-butyl} disulfide (S.19)

Engineering

Disulfide

Cross-Links in

RNA via Air Oxidation
57. Dissolve $0.10 \mathrm{~g}$ compound $\mathbf{S . 1 8}(0.21 \mathrm{mmol})$ and $13 \mathrm{mg}$ DMAP $(0.10 \mathrm{mmol}, 0.5 \mathrm{eq})$ in $0.8 \mathrm{~mL} \mathrm{DMF}$ and $26 \mu \mathrm{L}$ pyridine $(0.31 \mathrm{mmol}, 1.5 \mathrm{eq})$.

58. Add $85 \mathrm{mg} \mathrm{DMTrCl}(0.25 \mathrm{mmol}, 1.2 \mathrm{eq})$ and stir the reaction under $\mathrm{N}_{2}$ for $6 \mathrm{hr}$. 
59. Dilute the reaction with $\mathrm{CH}_{2} \mathrm{Cl}_{2}$ and wash with saturated aqueous $\mathrm{NaHCO}_{3}$ and brine.

60. Dry the organic layer over $\mathrm{Na}_{2} \mathrm{SO}_{4}$ and concentrate under vacuum.

61. Purify the residue by flash chromatography (APPENDIX 3E) using 1:1 (v/v) petroleum ether/acetone to obtain $\mathbf{S . 1 9}$ as a tan foam $(0.13 \mathrm{~g}, 77 \%$ yield $)$.

Prepare 5'-O-(4,4'-dimethoxytrityl)- $N^{4}$-(benzoyl)-2'-O-(ethyl)cytidine

3'-O-(N,N-diisopropyl-ß-cyanoethylphosphoramidite) tert-butyl disulfide (S.20)

62. Dissolve $55 \mathrm{mg}$ compound $\mathbf{S . 1 9}(0.07 \mathrm{mmol})$ in $0.3 \mathrm{~mL} \mathrm{CH} \mathrm{Cl}_{2}$ containing $60 \mu \mathrm{L}$ $N, N$-diisopropylethylamine $(0.35 \mathrm{mmol}, 5 \mathrm{eq})$.

63. Cool under $\mathrm{N}_{2}$ to $0^{\circ} \mathrm{C}$.

64. Add $23 \mu \mathrm{L}$ chloro- $N, N$-diisopropylamine- $\beta$-cyanoethyl phosphine $(0.10 \mathrm{mmol}, 1.5$ eq) dropwise and stir the reaction under $\mathrm{N}_{2}$ while allowing it to warm to room temperature.

65. After $2 \mathrm{hr}$, quench the excess chloridate with $0.3 \mathrm{~mL} \mathrm{CH}_{3} \mathrm{OH}$ and concentrate the mixture under vacuum.

66. Purify the residue by flash chromatography (APPENDIX $3 E)$ using 2:1 (v/v) petroleum ether/acetone to obtain $\mathbf{S . 2 0}$ as a white foam (58 mg, $84 \%$ yield).

SYNTHESIS OF 5'-O-(4,4'-DIMETHOXYTRITYL)-2'-O-(ETHYL)URIDINE-3'$O$-( $N, N$-DIISOPROPYL- $\beta$-CYANOETHYLPHOSPHORAMIDITE) tert-BUTYL DISULFIDE

The intermediate S.10 prepared in Support Protocol 6 can be converted to 3',5'-O(tetraisopropyldisiloxane-1,3-diyl)-2'-O-allyl uridine (S.21) using nitrobenzaldoxime and 1,1,3,3-tetramethylguanidine as described by Sproat and Lamond (1991). The synthesis of the fully protected phosphoramidites can be accomplished in nine sets of steps (Fig. 5.4.4).

\section{Materials}

2-Nitrobenzaldoxime

1,1,3,3-Tetramethylguanidine

Acetonitrile $\left(\mathrm{CH}_{3} \mathrm{CN}\right)$

Compound S.10 (see Support Protocol 6)

Ethyl acetate (EtOAc)

Sodium sulfate $\left(\mathrm{Na}_{2} \mathrm{SO}_{4}\right)$

Methanol $\left(\mathrm{CH}_{3} \mathrm{OH}\right)$

Methylene chloride $\left(\mathrm{CH}_{2} \mathrm{Cl}_{2}\right)$

Acetone

$\mathrm{N}$-Methylmorpholine- $\mathrm{N}$-oxide

Osmium tetroxide $\left(\mathrm{OsO}_{4}\right)$

Saturated aqueous sodium bisulfite

Celite

1,4-Dioxane

Sodium periodate $\left(\mathrm{NaIO}_{4}\right)$

Diethyl ether $\left(\mathrm{Et}_{2} \mathrm{O}\right)$

Sodium bicarbonate $\left(\mathrm{NaHCO}_{3}\right)$

Sodium borohydride $\left(\mathrm{NaBH}_{4}\right)$

Brine (saturated aqueous $\mathrm{NaCl}$ )

Pyridine 


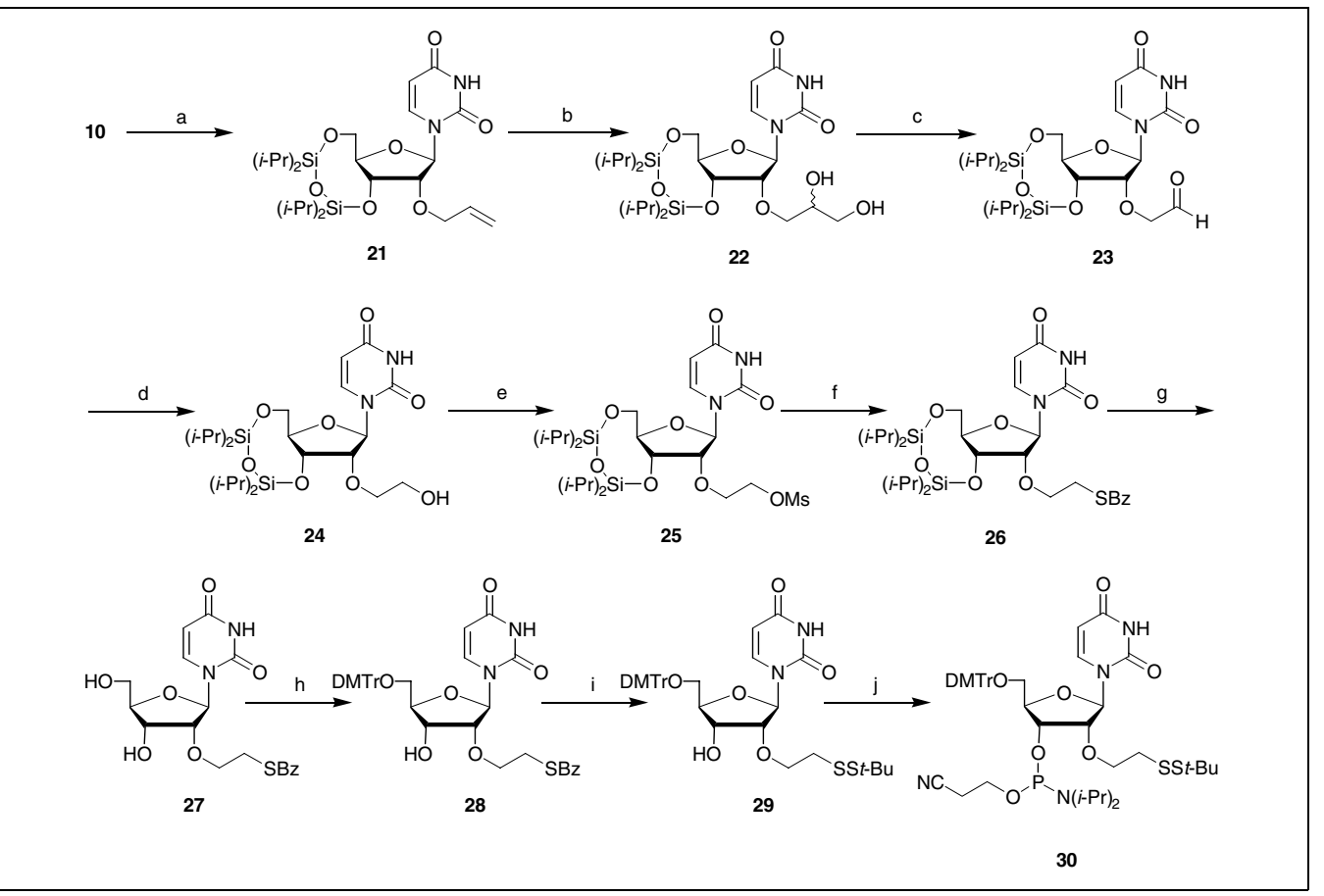

Figure 5.4.4 Synthesis of $3^{\prime}-O-(N, N$-diisopropyl- $\beta$-cyanoethyl-phosphoramidite)-5'-O-(4,4'-dimethoxytrityl)-2'-O-(ethyl)uridine tert-butyl disulfide. (a) 2-Nitrobenzaldoxime, 1,1,3,3-tetramethylguanidine, $\mathrm{CH}_{3} \mathrm{CN}$; (b) $\mathrm{OsO}_{4}, \mathrm{~N}$-methylmorpholine- $\mathrm{N}$-oxide, acetone, $\mathrm{H}_{2} \mathrm{O}$; (c) $\mathrm{NalO}_{4}$, p-dioxane, $\mathrm{H}_{2} \mathrm{O}$; (d) $\mathrm{NaBH}_{4}, \mathrm{CH}_{3} \mathrm{OH}$; (e) methanesulfonyl chloride, pyridine; (f) thiobenzoic acid, Et $3 \mathrm{~N}$, DMF; (g) $\mathrm{HF}(\mathrm{aq}), \mathrm{CH}_{3} \mathrm{CN}$; (h) DMTrCl, Et ${ }_{3} \mathrm{~N}$, DMF, DMAP; (i) 1-(tert-butylthio)-1,2-hydrazine-dicarboxmorpholide, $\mathrm{LiOH}, \mathrm{CH}_{3} \mathrm{OH}$, THF; (j) chloro- $N, N$-diisopropylamine- $\beta$-cyanoethyl phosphine, $N, N$ diisopropylethylamine, $\mathrm{CH}_{2} \mathrm{Cl}_{2}$. Abbreviations: $\mathrm{Bz}$, benzoyl; DMAP, 4-dimethylaminopyridine; DMF, dimethylformamide; DMTr, 4,4'-dimethoxytrityl; Ms, methanesulfonyl.

Methanesulfonyl chloride

$N, N$-Dimethylformamide (DMF)

Triethylamine $\left(\mathrm{Et}_{3} \mathrm{~N}\right)$

Thiobenzoic acid $48 \%(\mathrm{w} / \mathrm{v})$ aqueous $\mathrm{HF}$ 4,4'-Dimethoxytrityl chloride (DMTrCl)

4-Dimethylaminopyridine (DMAP)

Tetrahydrofuran (THF)

$\mathrm{LiOH} \cdot \mathrm{H}_{2} \mathrm{O}$

1-(tert-Butylthio)-1,2-hydrazinedicarboxmorpholide

$1 \mathrm{~N}$ aqueous sodium citrate

$N, N$-Diisopropylethylamine

Chloro- $N, N$-diisopropylamine- $\beta$-cyanoethyl phosphine

Petroleum ether

Additional reagents and equipment for flash chromatography (APPENDIX $3 E$ )

\section{Prepare 3',5'-O-(tetraisopropyldisiloxane-1,3-diyl)-2'-O-allyluridine (S.21)}

Engineering

Disulfide

Cross-Links in

RNA via Air Oxidation

1. Dissolve $2.1 \mathrm{~g}$ 2-nitrobenzaldoxime $(12.3 \mathrm{mmol}, 4 \mathrm{eq})$ and $1.4 \mathrm{~mL} \mathrm{1,1,3,3-tetra-}$ methylguanidine (11.1 mmol, $3.6 \mathrm{eq})$ in $28 \mathrm{~mL} \mathrm{CH}_{3} \mathrm{CN}$.

2. Stir this solution under $\mathrm{N}_{2}$.

3. Add the solution to $2.0 \mathrm{~g}$ compound $\mathbf{S . 1 0}$ (3.1 mmol). 
4. Stir the reaction for $30 \mathrm{~min}$ at room temperature and then concentrate under vacuum.

5. Dissolve the residue in EtOAc and wash with water.

6. Backwash the water layer 3 times with EtOAc.

7. Combine the organic layers and dry over $\mathrm{Na}_{2} \mathrm{SO}_{4}$.

8. Concentrate under vacuum.

9. Purify the residue by flash chromatography (APPENDIX $3 E$ ) using a step gradient of 0 to $5 \% \mathrm{CH}_{3} \mathrm{OH}$ in $\mathrm{CH}_{2} \mathrm{Cl}_{2}$ to obtain $\mathbf{S . 2 1}(1.61 \mathrm{~g}, 99 \%)$.

Prepare 3',5'-O-(tetraisopropyldisiloxane-1,3-diyl)-2'-O-(2,3-dihydroxypropyl)uridine (S.22)

10. Dissolve $1.61 \mathrm{~g}$ compound $\mathbf{S . 2 1}(3.06 \mathrm{mmol})$ in $30 \mathrm{~mL}$ of $6: 1(\mathrm{v} / \mathrm{v})$ acetone/water.

11. Add $394 \mathrm{mg} N$-methylmorpholine- $N$-oxide ( $3.4 \mathrm{mmol}, 1.1 \mathrm{eq})$ and $7.7 \mathrm{mg} \mathrm{OsO}_{4}(0.03$ mmol, $0.01 \mathrm{eq})$ and stir in the dark for $3 \mathrm{hr}$.

12. Precipitate the osmium salts with $2 \mathrm{~mL}$ saturated aqueous sodium bisulfite and pour the mixture through a funnel containing Celite.

13. Evaporate the solvent under vacuum to obtain $\mathbf{S . 2 2}$ as a white foam $(1.77 \mathrm{~g}, 100 \%$ yield).

Prepare 3',5'-O-(tetraisopropyldisiloxane-1,3-diyl)-2'-O-(ethanal)uridine (S.23)

14. Dissolve $437 \mathrm{mg}$ compound $\mathbf{S . 2 2}(0.8 \mathrm{mmol})$ in $7.8 \mathrm{~mL}$ of $3: 1$ (v/v) 1,4-dioxane/ $\mathrm{H}_{2} \mathrm{O}$.

15. Add $209 \mathrm{mg} \mathrm{NaIO} 4(1.0 \mathrm{mmol}, 1.25 \mathrm{eq})$ and stir the reaction in the dark for $6 \mathrm{hr}$.

16. Dilute the solution with $\mathrm{Et}_{2} \mathrm{O}$ and filter.

17. Wash the filtrate with saturated aqueous $\mathrm{NaHCO}_{3}$, dry over $\mathrm{Na}_{2} \mathrm{SO}_{4}$, and concentrate under vacuum to obtain $\mathbf{S . 2 3}$ as a pale-yellow foam (400 $\mathrm{mg}$, $97 \%$ yield).

Prepare 3',5'-O-(tetraisopropyldisiloxane-1,3-diyl)-2'-O-(2-hydroxyethyl)uridine (S.24)

18. Dissolve $470 \mathrm{mg}$ compound $\mathbf{S . 2 3}(0.9 \mathrm{mmol})$ in $7.4 \mathrm{~mL} \mathrm{CH}_{3} \mathrm{OH}$.

It may be necessary to repeat the synthesis of $\mathbf{S . 2 2}$ to obtain the necessary quantity for the synthesis of $\mathbf{S . 2 3 .}$

19. Add $16 \mathrm{mg} \mathrm{NaBH}_{4}(0.4 \mathrm{mmol}, 0.48 \mathrm{eq})$ and stir the mixture overnight under $\mathrm{N}_{2}$.

20. Dilute the mixture with $\mathrm{Et}_{2} \mathrm{O}$, then wash once with saturated aqueous $\mathrm{NaHCO}_{3}$ and twice with brine.

21. Dry the combined organic layers over $\mathrm{Na}_{2} \mathrm{SO}_{4}$, filter, and evaporate under vacuum to obtain $\mathbf{S . 2 4}$ as a white foam (464 mg, $98 \%$ yield).

Prepare 3',5'-O-(tetraisopropyldisiloxane-1,3-diyl)-2'-O-(ethyl-2-methylsulfonate) uridine (S.25)

22. Dissolve $138 \mathrm{mg}$ compound $\mathbf{S . 2 4}(0.3 \mathrm{mmol})$ in a mixture of $2.6 \mathrm{~mL} \mathrm{CH}_{2} \mathrm{Cl}_{2}$ and 0.21 $\mathrm{mL}$ pyridine.

23. Cool to $0^{\circ} \mathrm{C}$.

24. Add $28 \mu \mathrm{L}$ methanesulfonyl chloride ( $0.4 \mathrm{mmol}, 14 \mathrm{eq})$ dropwise while stirring under $\mathrm{N}_{2}$. 
25. Allow the reaction to warm to room temperature over $18 \mathrm{hr}$.

26. Dilute the mixture with $\mathrm{CH}_{2} \mathrm{Cl}_{2}$ and wash once with saturated aqueous $\mathrm{NaHCO}_{3}$.

27. Dry the organic layer over $\mathrm{Na}_{2} \mathrm{SO}_{4}$, filter, and evaporate under vacuum.

28. Purify the residue by flash chromatography (APPENDIX $3 E$ ) using 17:3 (v/v) $\mathrm{CH}_{2} \mathrm{Cl}_{2}$ /acetone to obtain $\mathbf{S . 2 5}$ as a white foam (133 $\mathrm{mg}, 84 \%$ yield).

\section{Prepare 3',5'-O-(tetraisopropyldisiloxane-1,3-diyl)-2'-O-(thiobenzoylethyl)uridine} (S.26)

29. Dissolve $552 \mathrm{mg}$ compound $\mathbf{S . 2 5}(0.9 \mathrm{mmol})$ in a mixture of $3.6 \mathrm{~mL}$ DMF and 1.3 $\mathrm{mL} \mathrm{Et}_{3} \mathrm{~N}$ (9.1 mmol, $\left.10.0 \mathrm{eq}\right)$.

It may be necessary to repeat the synthesis of $\mathbf{S . 2 5}$ to obtain the necessary quantity for the synthesis of $\mathbf{S . 2 6}$.

30. Add $0.21 \mathrm{~mL}$ thiobenzoic acid $(1.8 \mathrm{mmol}, 2 \mathrm{eq})$ and stir overnight under $\mathrm{N}_{2}$.

31. Dilute the mixture with $\mathrm{Et}_{2} \mathrm{O}$, then wash once with saturated aqueous $\mathrm{NaHCO}_{3}$ and twice with brine.

32. Dry the combined organic extracts over $\mathrm{Na}_{2} \mathrm{SO}_{4}$, filter, and concentrate under vacuum.

34. Purify the residue by flash chromatography (APPENDIX $3 E$ ) using a step gradient of 47:3 to $4: 1(\mathrm{v} / \mathrm{v}) \mathrm{CH}_{2} \mathrm{Cl}_{2} /$ acetone to obtain $\mathbf{S . 2 6}$ as a white foam (472 $\mathrm{mg}, 80 \%$ yield).

\section{Prepare 2'-O-(thiobenzoylethyl)uridine (S.27)}

35. Dissolve the $472 \mathrm{mg}$ compound $\mathbf{S . 2 6}(0.7 \mathrm{mmol})$ in $5.8 \mathrm{~mL} \mathrm{CH}_{3} \mathrm{CN}$.

36. Add $1.3 \mathrm{~mL}$ of $48 \%$ aqueous $\mathrm{HF}$ and stir for $4 \mathrm{hr}$.

37. Dilute the mixture with EtOAc and wash once with $\mathrm{H}_{2} \mathrm{O}$.

38. Dry the organic layer over $\mathrm{Na}_{2} \mathrm{SO}_{4}$ and filter.

39. Evaporate under vacuum to obtain $\mathbf{S . 2 7}$ as a white foam (327 $\mathrm{mg}, 100 \%$ yield).

\section{Prepare 5'-O-(4,4'-dimethoxytrityl)-2'-O-(thiobenzoylethyl)uridine (S.28)}

40. Dissolve $277 \mathrm{mg}$ compound $\mathbf{S . 2 7}(0.7 \mathrm{mmol})$ in $2.7 \mathrm{~mL}$ DMF and $82 \mu \mathrm{L}$ pyridine (1.0 mmol, $1.5 \mathrm{eq}$ ).

41. Add $280 \mathrm{mg}$ DMTrCl (0.8 mmol, $1.2 \mathrm{eq})$ and $54 \mathrm{mg}$ DMAP (0.4 mmol, $0.65 \mathrm{eq})$.

42. Stir the reaction overnight under $\mathrm{N}_{2}$.

43. Dilute the reaction with $\mathrm{CH}_{2} \mathrm{Cl}_{2}$ and wash the solution once with saturated aqueous $\mathrm{NaHCO}_{3}$ and twice with brine.

44. Dry the combined organic extracts over $\mathrm{Na}_{2} \mathrm{SO}_{4}$, filter, and concentrate under vacuum.

45. Purify the residue by flash chromatography (APPENDIX $3 E$ ) using 48:1 (v/v) $\mathrm{CH}_{2} \mathrm{Cl}_{2} / \mathrm{CH}_{3} \mathrm{OH}$ ) to obtain $\mathbf{S . 2 8}$ as a yellow foam (302 $\mathrm{mg}, 63 \%$ yield).

Engineering

Disulfide

Cross-Links in

RNA via Air Oxidation
Prepare 5'-O-(4,4'-dimethoxytrityl)-2'-O-(ethyl)uridine tert-butyl disulfide (S.29)

46. Dissolve $293 \mathrm{mg}$ compound $\mathbf{S . 2 8}(0.4 \mathrm{mmol})$ in $3.3 \mathrm{~mL}$ of $1: 1(\mathrm{v} / \mathrm{v}) \mathrm{THF} / \mathrm{CH}_{3} \mathrm{OH}$.

47. Add $26 \mathrm{mg} \mathrm{LiOH} \cdot \mathrm{H}_{2} \mathrm{O}(0.6 \mathrm{mmol}, 1.5 \mathrm{eq})$. 
48. After stirring for $2 \mathrm{~min}$, add $164 \mathrm{mg}$ 1-(tert-butylthio)-1,2-hydrazinedicarboxmorpholide (0.5 mmol, 1.2 eq) (Wünsch et al., 1982).

49. Stir the mixture for an additional 10 min under $\mathrm{N}_{2}$.

50. Dilute the solution with $\mathrm{CH}_{2} \mathrm{Cl}_{2}$.

51. Wash the solution with $1 \mathrm{~N}$ aqueous sodium citrate, saturated aqueous $\mathrm{NaHCO}_{3}$, and brine.

52. Dry the organic layer over $\mathrm{Na}_{2} \mathrm{SO}_{4}$.

53. Filter the solution and evaporate under vacuum.

54. Purify the residue by flash chromatography (APPENDIX $3 E$ ) using 49:1 (v/v) $\mathrm{CH}_{2} \mathrm{Cl}_{2} / \mathrm{CH}_{3} \mathrm{OH}$ to obtain $\mathbf{S . 2 9}$ as a white foam (285 mg, $100 \%$ yield).

Prepare 3'-O-(N,N-diisopropyl-p-cyanoethyl-phosphoramidite)-5'-O-(4,4'dimethoxytrityl)-2'-O-(ethyl)uridine tert-butyl disulfide (S.30)

55. Dissolve $49 \mathrm{mg}$ compound $\mathbf{S . 2 9}(0.07 \mathrm{mmol})$ in $0.28 \mathrm{~mL} \mathrm{CH}_{2} \mathrm{Cl}_{2}$ containing $62 \mu \mathrm{L}$ $\mathrm{N}, \mathrm{N}$-diisopropylethylamine $(0.4 \mathrm{mmol}, 5 \mathrm{eq})$ and cool to $0^{\circ} \mathrm{C}$.

56. Add $24 \mu \mathrm{L}$ chloro- $N, N$-diisopropylamine- $\beta$-cyanoethyl phosphine $(0.1 \mathrm{mmol}, 1.5 \mathrm{eq})$ dropwise.

57. Stir the mixture for $2 \mathrm{hr}$ under $\mathrm{N}_{2}$.

58. Dilute the solution with $\mathrm{CH}_{3} \mathrm{OH}$.

59. Concentrate the solution under vacuum.

60. Purify the residue by flash chromatography (APPENDIX 3E) using 19:6 (v/v) petroleum ether/acetone to obtain $\mathbf{S . 3 0}$ as a white foam (49 $\mathrm{mg}$, $78 \%$ yield).

\section{REAGENTS AND SOLUTIONS}

Use deionized, distilled water in all recipes and protocol steps. For common stock solutions, see APPENDIX 2A; for suppliers, see SUPPLIERS APPENDIX.

CPM buffer, $5 \times$

$7.6 \mathrm{~g}$ Tris $\cdot \mathrm{Cl}(250 \mathrm{mM})$

$38 \mathrm{~g} \mathrm{NaCl}(2.6 \mathrm{mM})$

$46.5 \mathrm{mg} \mathrm{Na} 2 \operatorname{EDTA}(0.5 \mathrm{mM})$

$0.38 \mathrm{~mL}$ Triton X-100 (0.15\%, v/v)

$\mathrm{H}_{2} \mathrm{O}$ to $200 \mathrm{~mL}$

Adjust $\mathrm{pH}$ to 7.5 with $1 \mathrm{~N} \mathrm{NaOH}$ or $\mathrm{HCl}$

Add $\mathrm{H}_{2} \mathrm{O}$ to $250 \mathrm{~mL}$

Store up to 1 month at $25^{\circ} \mathrm{C}$

\section{CPM in isopropanol, $0.4 \mathrm{mM}$}

Dissolve $1.6 \mathrm{mg}$ of 7-diethylamino-3-(4'-maleimidylphenyl)-4-methylcoumarin (Molecular Probes) in $10 \mathrm{~mL}$ HPLC-grade isopropanol. Store up to 1 week at $25^{\circ} \mathrm{C}$.

Denaturing polyacrylamide gel solution, $8 \%$

$0.32 \mathrm{~g}$ bisacrylamide

$9.28 \mathrm{~g}$ acrylamide

$57.7 \mathrm{~g}$ urea (8 M final)

$24 \mathrm{~mL} 5 \times$ TBE buffer (APPENDIX 2A)

$\mathrm{H}_{2} \mathrm{O}$ to $120 \mathrm{~mL}$

Prepare fresh daily

Methods for

Cross-Linking Nucleic Acids 
Dissolve $10.2 \mathrm{~g}$ magnesium chloride hexahydrate in $250 \mathrm{~mL}$ water. Store at room temperature (stable for several months).

\section{Sodium acetate, $1.5 \mathrm{M}, \mathrm{pH} 5.5$}

Dissolve $12.3 \mathrm{~g}$ anhydrous sodium acetate $(\mathrm{NaOAc})$ in $100 \mathrm{~mL}$ water. Adjust $\mathrm{pH}$ to 5.5 with glacial acetic acid. Store up to 6 months at $25^{\circ} \mathrm{C}$.

\section{Sodium phosphate buffer, $100 \mathrm{mM}, \mathrm{pH} 8.3$}

$17.8 \mathrm{~g} \mathrm{Na}_{2} \mathrm{HPO}_{4}$

$\mathrm{H}_{2} \mathrm{O}$ to $900 \mathrm{~mL}$

Adjust $\mathrm{pH}$ to 8.3 with $1 \mathrm{~N} \mathrm{H}_{3} \mathrm{PO}_{4}$ or $\mathrm{NaOH}$

Add $\mathrm{H}_{2} \mathrm{O}$ to $1 \mathrm{~L}$

Store up to 6 months at $25^{\circ} \mathrm{C}$

Sodium phosphate buffer/NaCl, pH 7.0

$100 \mathrm{mM}$ sodium phosphate buffer, $\mathrm{pH} 7.0$ (APPENDIX 2A)

$5 \mathrm{mM} \mathrm{NaCl}$ (APPENDIX 2A)

Check $\mathrm{pH}$ and adjust to 7.0 with $1 \mathrm{~N} \mathrm{H}_{3} \mathrm{PO}_{4}$ or $\mathrm{NaOH}$, if necessary

Store up to 6 months at $25^{\circ} \mathrm{C}$

\section{COMMENTARY}

\section{Background Information}

Generation of cysteine mutants in proteins capable of forming disulfide bonds is a useful technique to stabilize structure as well as to probe structure, folding, and dynamics. Disulfide cross-links have also been incorporated into DNA to examine ground-state structure, trap non-ground-state structures, and examine protein-DNA and DNA-DNA interactions (Glick, 1998). Disulfide cross-links have more recently been incorporated into RNA sequences to stabilize secondary structure (Goodwin and Glick, 1994; Allerson and Verdine, 1995), to examine dynamic motion between helices in the Tetrahymena ribozyme (Cohen and Cech, 1997), and to probe solution conformation of a tRNA, the hammerhead ribozyme, and the hairpin ribozyme (Sigurdsson et al., 1995; Goodwin et al., 1996; Earnshaw et al., 1997; Maglott and Glick, 1998).

The methods that have been used to incorporate disulfide bonds into RNA have relied on either air oxidation or thiol-disulfide exchange. Although air oxidation is slower than thiol-disulfide exchange, using the methodology presented here it is possible to achieve quantitative conversion of the purified thiolmodified RNA to disulfide-cross-linked RNA. The ability to form intramolecular disulfide cross-links in quantitative yields makes it possible to produce milligram quantities of these constructs, which can then be used in a wide variety of biophysical and biochemical experiments. In addition, attachment of the alkylthiol tethers at positions other than the $5^{\prime}$ or $3^{\prime}$ hydroxyls allows for radiolabeling of constructs modified at the termini of the RNA.

Disulfide cross-links can be incorporated into RNA secondary and tertiary structures at many different locations. The specific thiolmodified nucleosides that are needed to create a particular cross-link depend on the location of the cross-links within the RNA. It is possible to form cross-links between two of the same thiol-modified nucleosides or between two different thiol-modified nucleosides. The preparation of nucleosides with thiol modifications at the $N^{3}$ position of uridine as well as at the $2^{\prime}$ hydroxyl of both cytidine and uridine is described in this unit. Preparation of many other thiol-modified nucleosides has been reported, including those with alkylthiols on both $\mathrm{G}$ and A (Glick, 1998). Use of particular bases depends on the specific application (see Glick, 1998). The thiol group in each of these nucleosides is protected as a tert-butyl disulfide, which is stable to all conditions of solid-phase synthesis. These protocols involve relatively simple synthetic organic chemistry techniques and standard glassware and equipment. In addition to the thiol-modified nucleosides described here, synthesis of both adenosine and guanosine derivatized with 2 - $O$-alkyl linkers has been achieved (Manoharan et al., 1993; Douglas et al., 1994; Gundlach et al., 1997). 
Alkylthiol-modified nucleosides have also been described with linkers at, among others, the C5 position of pyrimidines (Sun et al., 1996), the C8 position of purines (Gundlach et al., 1997), and all exocyclic amine groups on both purines and pyrimidines (Allerson et al., 1997).

\section{Compound Characterization}

$N^{3}$-(2-Thiobenzoylethyl)uridine (S.1). TLC (9:1 $\left.\mathrm{CH}_{2} \mathrm{Cl}_{2} / \mathrm{CH}_{3} \mathrm{OH}\right) R_{\mathrm{f}}=0.41 .{ }^{1} \mathrm{H}$ NMR $(300$ $\left.\mathrm{MHz}, \mathrm{CD}_{3} \mathrm{CN}\right) \delta 3.30(2 \mathrm{H}, \mathrm{t}, J=5 \mathrm{~Hz}$, $\mathrm{CH}_{2} \mathrm{SC}(\mathrm{O}) \mathrm{Ar}$ ), 3.65-3.81 (2H, $2 \mathrm{dd}, J=2.5,10$ $\left.\mathrm{Hz}, 5^{\prime}, 5^{\prime \prime}\right), 3.96$ (1H, m, 4'), 4.16-4.19 (4H, m, $\left.2^{\prime}, 3^{\prime}, \mathrm{NCH}_{2}\right), 5.66(1 \mathrm{H}, \mathrm{d}, J=8.1 \mathrm{~Hz}, 6), 5.80$ $\left(1 \mathrm{H}, \mathrm{d}, J=3.8 \mathrm{~Hz}, 1^{\prime}\right), 7.43-7.62(3 \mathrm{H}, \mathrm{m}, \mathrm{Ar})$, $7.81(1 \mathrm{H}, \mathrm{d}, J=8.1 \mathrm{~Hz}, 5), 7.88(2 \mathrm{H}, \mathrm{d}, J=7.3$ $\mathrm{Hz}, \mathrm{Ar}) .{ }^{13} \mathrm{C}$ NMR $\left(75 \mathrm{MHz}, \mathrm{CD}_{3} \mathrm{CN}\right) \delta 27.4$ $\left(\mathrm{CH}_{2} \mathrm{SC}(\mathrm{O}) \mathrm{Ar}\right), 40.9\left(\mathrm{NCH}_{2}\right), 62.1\left(5^{\prime}\right), 70.8$ (3'), $75.6\left(2^{\prime}\right), 85.9\left(4^{\prime}\right), 91.8\left(1^{\prime}\right), 102.1$ (5), 128.0, 129.9, 134.7, 138.0 (Ar), 140.3 (6), 152.4 (2), 163.9 (4), 192.4 (SC(O)Ar). IR $(\mathrm{KBr}) \vee \mathrm{3548,} 3448,3086,3060,2944,2901$, 1706, 1673, 1655, 1462, 1388, 1286, 1211, $1124,1079,919,813,779,695,647,569 \mathrm{~cm}^{-1}$. MS (FAB, 3-NBA/trifluoroacetic acid) $m / z, 409$ $\left(\mathrm{M}^{+}+1\right)$.

$5^{\prime}-O-\left(4,4^{\prime}\right.$-Dimethoxytrityl)- $N^{3}$-(ethyl)uridine tert-butyl disulfide (S.2). ${ }^{1} \mathrm{H}$ NMR $(360 \mathrm{MHz}$, $\left.\mathrm{CD}_{3} \mathrm{CN}\right) \delta 1.31\left(9 \mathrm{H}, \mathrm{s}, \mathrm{SS}\left(\mathrm{CH}_{3}\right)_{3}\right), 2.90(2 \mathrm{H}$, $\left.\mathrm{t}, \mathrm{J}=6.0 \mathrm{~Hz}, \mathrm{CH}_{2} \mathrm{SS}\right), 3.36\left(2 \mathrm{H}, \mathrm{m}, 5^{\prime}, 5^{\prime \prime}\right), 3.75$ $\left(6 \mathrm{H}, \mathrm{s}, 2 \mathrm{OCH}_{3}\right), 4.02\left(1 \mathrm{H}, \mathrm{m}, 4^{\prime}\right), 4.11(2 \mathrm{H}$, $\left.\mathrm{m}, \mathrm{NCH}_{2}\right), 4.18\left(1 \mathrm{H}, \mathrm{m}, 2^{\prime}\right), 4.32\left(1 \mathrm{H}, \mathrm{m}, 3^{\prime}\right)$, $5.38(1 \mathrm{H}, \mathrm{d}, J=8.1 \mathrm{~Hz}, 6), 5.78(1 \mathrm{H}, \mathrm{d}, J=3.2$ $\left.\mathrm{Hz}, 1^{\prime}\right), 6.85-7.44$ (13H, m, Ar), 7.73 (1H, d, $J$ $=8.1 \mathrm{~Hz}, 5) \cdot{ }^{13} \mathrm{C} \mathrm{NMR}\left(90 \mathrm{MHz}, \mathrm{CD}_{3} \mathrm{CN}\right) \delta$ $30.1\left(\mathrm{SSC}\left(\mathrm{CH}_{3}\right)_{3}\right), \quad 37.2\left(\mathrm{CH}_{2} \mathrm{SS}\right), 41.0$ $\left(\mathrm{NCH}_{2}\right), 48.5\left(\mathrm{SSC}\left(\mathrm{CH}_{3}\right)_{3}\right), 56.0\left(\mathrm{OCH}_{3}\right), 63.4$ (5'), $70.5\left(3^{\prime}\right), 75.5\left(2^{\prime}\right), 83.8\left(4^{\prime}\right), 87.5$ $\left(\mathrm{OC}(\mathrm{Ph})_{3}\right), 91.4\left(1^{\prime}\right), 101.9(5), 114.2(\mathrm{Ar})$, 128.0, 129.0, 131.1, 136.5, 136.7 (Ar), 139.7 (6), 145.9 (Ar), 152.0 (2), 159.8 (Ar), 163.3 (4). IR (film; NaCl) v 3452, 2959, 2940, 1708 , 1665, 1608, 1509, 1457, 1252, 1177, 1103, $1035,829,810,702 \mathrm{~cm}^{-1}$. MS (FAB, 3-NBA) $m / z, 695\left(\mathrm{M}^{+}+1\right)$.

$5^{\prime}-O$-(4,4'-Dimethoxytrityl)-2'-O-(tert-butyldimethylsilyl)- $N^{3}$-(ethyl)uridine tert-butyl disulfide (S.3) TLC (4:1 petroleum ether/EtOAc) $R_{\mathrm{f}}=0.30 .{ }^{1} \mathrm{H}$ NMR $\left(300 \mathrm{MHz}, \mathrm{CD}_{3} \mathrm{CN}\right) \delta 0.12$ $\left(6 \mathrm{H}, \mathrm{s}, \mathrm{Si}\left(\mathrm{CH}_{3}\right)_{2}\right), 0.90\left(9 \mathrm{H}, \mathrm{s}, \mathrm{SiC}\left(\mathrm{CH}_{3}\right)_{3}\right), 1.30$ $\left(9 \mathrm{H}, \mathrm{s}, \mathrm{SSC}\left(\mathrm{CH}_{3}\right)_{3}\right), 2.88(2 \mathrm{H}, \mathrm{t}, J=8.0 \mathrm{~Hz}$, $\left.\mathrm{CH}_{2} \mathrm{HS}\right), 3.38(2 \mathrm{H}, 2 \mathrm{dd}, J=2.4,11.0 \mathrm{~Hz}$, $\left.5^{\prime}, 5^{\prime \prime}\right), 3.74\left(6 \mathrm{H}, \mathrm{s}, 2 \mathrm{OCH}_{3}\right), 4.05\left(3 \mathrm{H}, \mathrm{m}, 4^{\prime}\right.$, $\left.\mathrm{NCH}_{2}\right), 4.24\left(1 \mathrm{H}, \mathrm{m}, 2^{\prime}\right), 4.31\left(1 \mathrm{H}, \mathrm{m}, 3^{\prime}\right), 5.35$ $(1 \mathrm{H}, \mathrm{d}, J=8.2 \mathrm{~Hz}, 6), 5.83(1 \mathrm{H}, \mathrm{d}, J=4.0 \mathrm{~Hz}$, 1'), 6.84-7.43 (13H, m, Ar), 7.74 (1H, d, $J=8.1$
$\mathrm{Hz}, 5) .{ }^{13} \mathrm{C}$ NMR $\left(75 \mathrm{MHz}, \mathrm{CD}_{3} \mathrm{CN}\right) \delta-4.4$ $\left(\mathrm{Si}\left(\mathrm{CH}_{3}\right)_{2}\right), \quad 18.8 \quad\left(\mathrm{SiC}\left(\mathrm{CH}_{3}\right)_{3}\right), \quad 26.3$ $\left(\mathrm{SiC}\left(\mathrm{CH}_{3}\right)_{3}\right), \quad 30.2 \quad\left(\mathrm{~S} \mathrm{SC}\left(\mathrm{CH}_{3}\right)_{3}\right), \quad 37.5$ $\left(\mathrm{CH}_{2} \mathrm{SS}\right), 41.0\left(\mathrm{NCH}_{2}\right), 48.4\left(\mathrm{SSC}\left(\mathrm{CH}_{3}\right)_{3}\right)$, $55.9\left(\mathrm{OCH}_{3}\right), 63.7\left(5^{\prime}\right), 71.2\left(3^{\prime}\right), 76.9\left(2^{\prime}\right), 84.1$ $\left(4^{\prime}\right), 87.7\left(\mathrm{OC}(\mathrm{Ph})_{3}\right), 90.6\left(1^{\prime}\right), 102.1(5), 114.1$ (Ar), 127.8, 128.8, 128.9, 130.9, 136.3, 136.5 (Ar), 139.3 (6), 145.6 (Ar), 151.7 (2), 159.7 (Ar), 162.8 (4). IR (film; NaCl) v 3856, 3546, 2955, 2930, 2857, 2361, 2334, 1710, 1668, $1608,1509,1456,1253,1177,1122,1036,836$ $\mathrm{cm}^{-1}$. MS (FAB, 3-NBA) $m / z 809\left(\mathbf{M}^{+}+1\right)$.

$5^{\prime}-O$-(4,4'-Dimethoxytrityl)-3'-O-(tert-butyldimethylsilyl)- $N^{3}$-(ethyl)uridine tert-butyl disulfide (S.4) TLC (4:1 petroleum ether/EtOAc) $R_{\mathrm{f}}=0.14 .{ }^{1} \mathrm{H} \mathrm{NMR}\left(300 \mathrm{MHz}, \mathrm{CD}_{3} \mathrm{CN}\right) \delta 0.04$, $0.05\left(6 \mathrm{H}, 2 \mathrm{~s}, \mathrm{Si}\left(\mathrm{CH}_{3}\right)_{2}\right), 0.81(9 \mathrm{H}, \mathrm{s}$, $\left.\mathrm{SiC}\left(\mathrm{CH}_{3}\right)_{3}\right), 1.30\left(9 \mathrm{H}, \mathrm{s}, \mathrm{SSC}\left(\mathrm{CH}_{3}\right)_{3}\right), 2.88$ $\left(1 \mathrm{H}, \mathrm{dd}, J=3.8,11.1 \mathrm{~Hz}, 5^{\prime}\right), 2.89(2 \mathrm{H}, \mathrm{t}, J=$ $\left.7.6 \mathrm{~Hz}, \mathrm{CH}_{2} \mathrm{SS}\right), 3.46(1 \mathrm{H}$, dd, $J=2.4,11.0 \mathrm{~Hz}$, $\left.5^{\prime \prime}\right), 3.74\left(6 \mathrm{H}, \mathrm{s}, 2 \mathrm{OCH}_{3}\right), 4.00\left(1 \mathrm{H}, \mathrm{m}, 4^{\prime}\right)$, $4.10\left(3 \mathrm{H}, \mathrm{m}, 2^{\prime}, \mathrm{NCH}_{2}\right), 4.33\left(1 \mathrm{H}, \mathrm{m}, 3^{\prime}\right), 5.38$ $(1 \mathrm{H}, \mathrm{d}, J=8.1 \mathrm{~Hz}, 6), 5.80(1 \mathrm{H}, \mathrm{d}, J=3.0 \mathrm{~Hz}$, $\left.1^{\prime}\right), 6.84-7.42$ (13H, m, Ar), $7.74(1 \mathrm{H}, \mathrm{d}, J=8.1$ $\mathrm{Hz}, 5) .{ }^{13} \mathrm{C}$ NMR (75 MHz, $\left.\mathrm{CD}^{3} \mathrm{CN}\right) \delta-4.4$, $-4.1\left(\mathrm{Si}\left(\mathrm{CH}_{3}\right)_{2}\right), 18.7\left(\mathrm{SiC}\left(\mathrm{CH}_{3}\right)_{3}\right), 26.3$ $\left(\mathrm{SiC}\left(\mathrm{CH}_{3}\right)_{3}\right), \quad 30.3 \quad\left(\mathrm{~S} \mathrm{SC}\left(\mathrm{CH}_{3}\right)_{3}\right), \quad 37.5$ $\left(\mathrm{CH}_{2} \mathrm{SS}\right), 41.0\left(\mathrm{NCH}_{2}\right), 48.3\left(\mathrm{SSC}\left(\mathrm{CH}_{3}\right)_{3}, 56.0\right.$ $\left(\mathrm{OCH}_{3}\right), 63.3\left(5^{\prime}\right), 72.0\left(^{\prime}\right), 75.4\left(2^{\prime}\right), 84.1\left(^{\prime}\right)$, $87.7\left(\mathrm{OC}(\mathrm{Ph})_{3}\right), 92.0\left(1^{\prime}\right), 102.1(5), 114.1(\mathrm{Ar})$, 127.7, 128.7, 129.0, 131.0, 136.4 (Ar), 139.6 (6), 145.5 (Ar), 151.7 (2), 159.7 (Ar), 162.9(4). IR (film; NaCl) v 3869, 2955, 2929, 2858, 2364, 2334, 1710, 1670, 1509, 1456, 1252, $1176,1116,1035,836 \mathrm{~cm}^{-1}$. MS (FAB, 3NBA) $m / z 809\left(\mathbf{M}^{+}+1\right)$.

$5^{\prime}-O$-(4,4'-Dimethoxytrityl)-2'-O-(tert-butyldimethylsilyl)- $N^{3}$-(ethyl)uridine-3'-O-(N,N-diisopropyl- $\beta$-cyanoethylphosphoramidite) tertbutyl disulfide (S.5). TLC (80:15:5 petroleum ether/EtOAc/Et $\left.{ }_{3} \mathrm{~N}\right) R_{\mathrm{f}}=0.28 .{ }^{1} \mathrm{H}$ NMR (300 $\mathrm{MHz}, \mathrm{CD}_{3} \mathrm{CN}$ ) $\delta$ (two diastereomers) 0.09 , $0.12\left(6 \mathrm{H}, 2 \mathrm{~s}, \mathrm{Si}\left(\mathrm{CH}_{3}\right)_{2}\right), 0.83,0.85(9 \mathrm{H}, 2 \mathrm{~s}$, $\left.\mathrm{SiC}\left(\mathrm{CH}_{3}\right)_{3}\right), 1.01,1.14(12 \mathrm{H}, \mathrm{d}, J=9 \mathrm{~Hz}, 2$ $\left.\mathrm{NCH}\left(\mathrm{CH}_{3}\right)_{2}\right), 1.31\left(9 \mathrm{H}, \mathrm{s}, \mathrm{SSC}\left(\mathrm{CH}_{3}\right)_{3}\right), 2.45$ $\left(2 \mathrm{H}, \mathrm{m}, \mathrm{OCH}_{2} \mathrm{CH}_{2} \mathrm{CN}\right), 2.88\left(2 \mathrm{H}, \mathrm{m}, \mathrm{CH}_{2} \mathrm{SS}\right)$, $3.40\left(2 \mathrm{H}, \mathrm{m}, 5^{\prime}, 5^{\prime \prime}\right), 3.50-3.90(4 \mathrm{H}, \mathrm{m}$, $\left.\mathrm{OCH}_{2} \mathrm{CH}_{2} \mathrm{CN}, 2 \mathrm{NCH}\left(\mathrm{CH}_{3}\right)_{2}\right), 3.75(6 \mathrm{H}, \mathrm{s}, 2$ $\left.\mathrm{OCH}_{3}\right), 4.10\left(2 \mathrm{H}, \mathrm{m}, \mathrm{NCH}_{2} \mathrm{CH}_{2} \mathrm{SS}\right), 4.20-4.42$ $\left(3 \mathrm{H}, \mathrm{m}, 2^{\prime}, 3^{\prime}, 4^{\prime}\right), 5.37,5.39(1 \mathrm{H}, \mathrm{d}, J=8.1 \mathrm{~Hz}$, 6), $5.84,5.89\left(1 \mathrm{H}, \mathrm{d}, J=6.6 \mathrm{~Hz}, 1^{\prime}\right), 6.83-7.46$ (13H, m, Ar), 7.72, $7.77(1 \mathrm{H}, \mathrm{d}, J=8.1 \mathrm{~Hz}, 5)$. ${ }^{13} \mathrm{C}$ NMR $\left(75 \mathrm{MHz}, \mathrm{CD}_{3} \mathrm{CN}\right) \delta$ (two diastereomers) -4.2 $\left(\mathrm{Si}\left(\mathrm{CH}_{3}\right)_{2}\right), 18.9\left(\mathrm{SiC}\left(\mathrm{CH}_{3}\right)_{3}\right)$, $21.1\left(\mathrm{OCH}_{2} \mathrm{CH}_{2} \mathrm{CN}\right), 25.0,25.1,25.2,25.3$ $\left(\mathrm{NCH}\left(\mathrm{CH}_{3}\right)_{2}\right), \quad 26.4 \quad\left(\mathrm{SiC}\left(\mathrm{CH}_{3}\right)_{3}\right), \quad 30.4$ $\left(\mathrm{SC}\left(\mathrm{CH}_{3}\right)_{3}\right), 37.8\left(\mathrm{CH}_{2} \mathrm{SS}\right), 41.2\left(\mathrm{NCH}_{2}\right.$
Methods for Cross-Linking Nucleic Acids 
$\left.\mathrm{CH}_{2} \mathrm{SS}\right), 44.1,44.3,44.5,44.6\left(\mathrm{NCH}\left(\mathrm{CH}_{3}\right)_{2}\right)$, $48.5\left(\mathrm{SSC}\left(\mathrm{CH}_{3}\right)_{3}\right), 56.2\left(\mathrm{OCH}_{3}\right), 59.4,60.0$ $\left(\mathrm{POCH}_{2} \mathrm{CH}_{2} \mathrm{CN}\right.$ ), 64.0, 64.2 (5'), 73.5, 73.7 (3'), 76.1, 76.5 (2'), 83.9, 84.0 (4'), 88.1 $\left(\mathrm{OC}(\mathrm{Ph})_{3}\right), 90.3,90.4\left(1^{\prime}\right), 102.4,102.5$ (5), 114.4 (Ar), 128.1, 129.0, 129.2, 129.3, 131.2, 136.4, 136.5, 136.6 (Ar), 139.3, 139.4 (6), 145.7, 145.8 (Ar), 152.1 (2), 160.0 (Ar), 162.9, 163.0 (4). ${ }^{31} \mathrm{P} \mathrm{NMR}\left(202 \mathrm{MHz}, \mathrm{CD}_{3} \mathrm{CN}\right) \delta$ (two diastereomers) 147.4 , 146.8. IR (KBr) $\vee 2965$, 2931, 2859, 2254, 1712, 1671, 1611, 1509, 1456, 1391, 1365, 1253, 1179, 1037, 979, 836 $\mathrm{cm}^{-1}$. MS (FAB, 3-NBA) $\mathrm{m} / 2$, $1009.5\left(\mathrm{M}^{+}+1\right)$. Anal. Calcd for $\mathrm{C}_{51} \mathrm{H}_{73} \mathrm{~N}_{4} \mathrm{O}_{9} \mathrm{PS}_{2} \mathrm{Si}$ : C, 60.70; H, 7.28; N, 5.55. Found: C, 60.77; H, 7.24; N, 5.47.

$5^{\prime}-O$-(4,4'-Dimethoxytrityl)-3'-O-(tert-butyldimethylsilyl)-2'-O-pentachlorophenylsuccinate $N 3$-(ethyl)uridine tert-butyl disulfide (S.6). TLC (4:1 petroleum ether/EtOAc) $R_{\mathrm{f}}=0.68 .{ }^{1} \mathrm{H}$ NMR $\left(360 \mathrm{MHz}, \mathrm{CD}_{3} \mathrm{CN}\right) \delta-0.07,0.01(6 \mathrm{H}$, $\left.\mathrm{s}, \mathrm{Si}\left(\mathrm{CH}_{3}\right)_{2}\right), 0.79\left(9 \mathrm{H}, \mathrm{s}, \mathrm{SiC}\left(\mathrm{CH}_{3}\right)_{3}\right), 1.29(9 \mathrm{H}$, s, $\left.\mathrm{SSC}\left(\mathrm{CH}_{3}\right)_{3}\right), 2.79\left(4 \mathrm{H}, \mathrm{m}\right.$, succinate $\left.\mathrm{CH}_{2}\right)$, $3.03\left(2 \mathrm{H}, \mathrm{m}, \mathrm{CH}_{2} \mathrm{SS}\right), 3.29-3.47\left(2 \mathrm{H}, \mathrm{m}, 5^{\prime}, 5^{\prime \prime}\right)$, $3.76\left(6 \mathrm{H}, \mathrm{s}, 2 \mathrm{OCH}_{3}\right), 3.96-4.12\left(3 \mathrm{H}, \mathrm{m}, 4^{\prime}\right.$, $\left.\mathrm{NCH}_{2}\right), 4.38\left(1 \mathrm{H}, \mathrm{m}, 3^{\prime}\right), 5.43\left(2 \mathrm{H}, \mathrm{m}, 6,2^{\prime}\right)$, $5.97\left(1 \mathrm{H}, \mathrm{d}, J=4.8 \mathrm{~Hz}, 1^{\prime}\right), 6.21-7.45(13 \mathrm{H}, \mathrm{m}$, $\mathrm{Ar}), 7.65(1 \mathrm{H}, \mathrm{d}, J=8.1 \mathrm{~Hz}, 5) .{ }^{13} \mathrm{C}$ NMR $(90$ $\left.\mathrm{MHz}, \mathrm{CD}_{3} \mathrm{CN}\right) \delta-4.4,-4.1\left(\mathrm{Si}\left(\mathrm{CH}_{3}\right)_{2}\right), 18.6$ $\left(\mathrm{SiC}\left(\mathrm{CH}_{3}\right)_{3}\right), 26.1\left(\mathrm{SiC}\left(\mathrm{CH}_{3}\right)_{3}\right), 29.4,29.5$ (succinate $\left.\mathrm{CH}_{2}\right), 30.2\left(\mathrm{SSC}\left(\mathrm{CH}_{3}\right)_{3}\right), 37.0$ $\left(\mathrm{CH}_{2} \mathrm{SS}\right), \quad 41.1 \quad\left(\mathrm{NCH}_{2} \mathrm{CH}_{2} \mathrm{SS}\right), \quad 48.5$ $\left(\mathrm{SSC}\left(\mathrm{CH}_{3}\right)_{3}\right), 56.0\left(\mathrm{OCH}_{3}\right), 63.6\left(5^{\prime}\right), 71.4\left(3^{\prime}\right)$, $76.1\left(2^{\prime}\right), 85.3\left(4^{\prime}\right), 88.0\left(\mathrm{OC}(\mathrm{Ph})_{3}\right), 88.7\left(1^{\prime}\right)$, 102.5 (5), 114.2 (Ar), 128.1, 129.0, 129.1, 131.2, 136.4 (Ar), 139.4 (6), 145.7 (Ar), 152.0 (2), 159.9 (Ar), 163.1 (4), 169.6, 171.8 (succinate $\mathrm{CO}_{2}$ ). IR (film; $\mathrm{NaCl}$ ) v 2956, 2931, 1786 , 1751, 1713, 1672, 1608, 1509, 1455, 1390, 1363, 1253, 1229, 1177, 1154, 1107, 1036, 837 $\mathrm{cm}^{-1}$. MS (FAB, 3-NBA) $\mathrm{m} / z 1173\left(\mathrm{M}^{+}+1\right)$. Anal. Calcd for $\mathrm{C}_{52} \mathrm{H}_{59} \mathrm{~N}_{2} \mathrm{O}_{11} \mathrm{~S}_{2} \mathrm{SiCl}_{5}$ : C, 53.96; H, 5.10; N, 2.42. Found C, 54.03; H, 5.15; N, 2.40 .

$3^{\prime}, 5^{\prime}-O$-(Tetraisopropyldisiloxane-1,3-diyl)uridine (S.8). TLC (1:1 petroleum ether/ EtOAc) $R_{\mathrm{f}} 0.28 ;{ }^{1} \mathrm{H}$ NMR $\left(300 \mathrm{MHz}, \mathrm{CDCl}_{3}\right)$ $\delta$ 1.03-1.11 (28H, $\mathrm{m}$, isopropyl), 3.56-4.40 $\left(5 \mathrm{H}, \mathrm{m}, 2^{\prime}, 3^{\prime}, 4^{\prime}, 5^{\prime}, 5^{\prime \prime}\right), 5.70(1 \mathrm{H}, \mathrm{dd}, 5), 5.74$ $\left(1 \mathrm{H}, \mathrm{s}, 1^{\prime}\right), 7.71(1 \mathrm{H}, \mathrm{d}, 6), 8.83(1 \mathrm{H}, \mathrm{s}, \mathrm{NH})$; ${ }^{13} \mathrm{C}$ NMR $\left(90 \mathrm{MHz}, \mathrm{CDCl}_{3}\right) \delta$ 12.63-13.55 (isopropyl CHs), 16.98-17.65 (isopropyl $\left.\mathrm{CH}_{3} \mathrm{~s}\right), 60.29\left(5^{\prime}\right), 68.85\left(3^{\prime}\right), 75.32\left(2^{\prime}\right), 82.05$ (4'), 91.15 (1'), 102.18 (5), 140.10 (6), 150.48 (2), 163.84 (4); IR ( $\mathrm{KBr}$ pellet) $\vee 3434,3200$, 3063, 2946, 2868, 1703, 1465, 1388, 1270, 1211, 1123, 1091, 1060, 1038, 993, 907, 885,
861, 809, 774, 705, $553 \mathrm{~cm}^{-1}$; MS (CI, $\left.\mathrm{CH}_{4}\right)$ $\mathrm{m} / \mathrm{z} 487\left(\mathrm{MH}^{+}\right)$.

3',5'-O-(Tetraisopropyldisiloxane-1,3-diyl)$O^{4}$-(2-nitrophenyl) uridine (S.9). TLC (1:1 petroleum ether/EtOAc) $R_{\mathrm{f}} 0.27 ;{ }^{1} \mathrm{H}$ NMR $(300$ $\left.\mathrm{MHz}, \mathrm{CDCl}_{3}\right) \delta 1.00-1.11$ (28H, m, isopropyl), 3.99-4.37 (5H, m, 2', 3', $\left.4^{\prime}, 5^{\prime}, 5^{\prime \prime}\right), 5.74(1 \mathrm{H}, \mathrm{s}$, $\left.1^{\prime}\right), 6.21(1 \mathrm{H}, \mathrm{d}, 5), 7.32(1 \mathrm{H}, \mathrm{d}, \mathrm{Ar}), 7.41(1 \mathrm{H}$, ddd, Ar), 7.67 (1H, ddd, Ar), 8.13 (1H, dd, Ar), $8.23(1 \mathrm{H}, \mathrm{d}, 6) ;{ }^{13} \mathrm{C} \mathrm{NMR}\left(75 \mathrm{MHz}, \mathrm{CDCl}_{3}\right) \delta$ 12.89-13.70 (isopropyl CHs), 17.14-17.71 (isopropyl $\mathrm{CH}_{3} \mathrm{~s}$ ), $60.71\left(5^{\prime}\right), 69.28$ (3'), 75.29 (2'), $82.34\left(4^{\prime}\right), 92.46\left(1^{\prime}\right), 94.78(5), 125.76$, $126.14,126.81,134.88,141.90,145.08$ (Ar), 145.19 (6), 154.68 (2), 171.10 (4).

$3^{\prime}, 5^{\prime}-O$-(Tetraisopropyldisiloxane-1,3-diyl)$2^{\prime}$ - $O$-allyl- $O^{4}$-(2-nitrophenyl) uridine (S.10). TLC (1:1 petroleum ether/EtOAc) $R_{\mathrm{f}} 0.68 .{ }^{1} \mathrm{H}$ NMR $\left(300 \mathrm{MHz}, \mathrm{CDCl}_{3}\right) \delta 1.00-1.12(28 \mathrm{H}, \mathrm{m}$, isopropyl), 3.93-4.44 (7H, $\mathrm{m}, 2^{\prime}, 3,4^{\prime}, 5^{\prime}, 5^{\prime \prime}$, allyl $\left.\mathrm{CH}_{2}\right), 5.16\left(1 \mathrm{H}, \mathrm{ddd},=\mathrm{CH}_{2 \mathrm{a}}\right), 5.39(1 \mathrm{H}, \mathrm{m}$, $\left.=\mathrm{CH}_{2 \mathrm{~b}}\right), 5.76\left(1 \mathrm{H}, \mathrm{s}, 1^{\prime}\right), 5.92(1 \mathrm{H}, \mathrm{m}, \mathrm{CH}=)$, $6.19(1 \mathrm{H}, \mathrm{d}, 5), 7.33(1 \mathrm{H}, \mathrm{dd}, \mathrm{Ar}), 7.41(1 \mathrm{H}, \mathrm{ddd}$, Ar), 7.67 (1H, ddd, Ar), 8.13 (1H, dd, Ar), 8.38 $(1 \mathrm{H}, \mathrm{d}, 6) ;{ }^{13} \mathrm{C}$ NMR $\left(75 \mathrm{MHz}, \mathrm{CDCl}_{3}\right) \delta$ 12.92-13.79 (isopropyl $\mathrm{CHs),} \mathrm{17.16-17.79}$ (isopropyl $\mathrm{CH}_{3} \mathrm{~s}$ ), $59.85\left(5^{\prime}\right), 68.04\left(3^{\prime}\right), 71.51$ $\left(\mathrm{OCH}_{2}\right), 81.02\left(2^{\prime}\right), 82.16\left(4^{\prime}\right), 90.46\left(1^{\prime}\right), 94.50$ (5), $117.29\left(=\mathrm{CH}_{2}\right), 125.80,126.13,126.76$, $134.73(\mathrm{Ar}), 134.82(\mathrm{CH}=), 142.00(\mathrm{Ar})$, 144.77 (6), 145.26 (Ar) 154.72 (2), 171.06 (4); IR (KBr pellet) v 3105, 2947, 2869, 1683, 1633, 1603,1549 , 1531, 1454, 1365, 1351, 1288, 1220, 1166, 1126, 1073, 1041, 1014, 991, 886, 858, 780, $698 \mathrm{~cm}^{-1}$; MS (CI, $\left.\mathrm{CH}_{4}\right) \mathrm{m} / \mathrm{z} 648$ $\left(\mathrm{M}^{+}\right)$.

$3^{\prime}, 5^{\prime}-O$-(Tetraisopropyldisiloxane-1,3-diyl)$N^{4}$-(benzoyl)-2'-O-allyl cytidine (S.11). TLC (2:3 EtOAc/petroleum ether) $R_{\mathrm{f}}=0.32 .{ }^{1} \mathrm{H}$ NMR $\left(300 \mathrm{MHz}, \mathrm{CDCl}_{3}\right) \delta 0.96-1.11(28 \mathrm{H}, \mathrm{m}$, $\left.4\left(\mathrm{CH}_{3}\right)_{2} \mathrm{HSi}, 4\left(\mathrm{CH}_{3}\right)_{2} \mathrm{HSi}\right), 3.95-4.02(2 \mathrm{H}, \mathrm{m}$, $\left.2^{\prime}-\mathrm{H}, 5^{\prime}-H_{\mathrm{a}}\right), 4.16\left(1 \mathrm{H}, \mathrm{dd}, \mathrm{J}=4.1,9.6 \mathrm{~Hz}, 3^{\prime}-\mathrm{H}\right)$, 4.24-4.32 (2H, m, 4'-H, 5'- $\left.H_{\mathrm{b}}\right), 4.39-4.52(2 \mathrm{H}$, $\left.\mathrm{m}, 7-H_{\mathrm{a}, \mathrm{b}}\right), 5.19\left(1 \mathrm{H}, \mathrm{d}, J=10.5 \mathrm{~Hz}, 9-H_{\text {trans }}\right)$, $5.42\left(1 \mathrm{H}, \mathrm{d}, J=16.0 \mathrm{~Hz}, 9-H_{\mathrm{cis}}\right), 5.84(1 \mathrm{H}, \mathrm{s}$, $\left.1^{\prime}-H\right), 5.87-6.00(1 \mathrm{H}, \mathrm{m}, 8-H), 7.47-7.62(4 \mathrm{H}$, $\mathrm{m}, 5-H, \operatorname{Ar} H), 7.90-7.92(2 \mathrm{H}, \mathrm{m}, \mathrm{Ar} H), 8.39$ $(1 \mathrm{H}, \mathrm{d}, J=7.5 \mathrm{~Hz}, 6-H) .{ }^{13} \mathrm{C}$ NMR $(75 \mathrm{MHz}$, $\left.\left.\mathrm{CDCl}_{3}\right) \delta 12.6,13.0,13.2,13.5\left(\left(\mathrm{CH}_{3}\right)_{2}\right) C \mathrm{HSi}\right)$, $\left.16.9,17.0,17.1,17.4,17.5\left(\left(\mathrm{CH}_{3}\right)_{2}\right) \mathrm{CHSi}\right)$, $59.5\left(5^{\prime}\right), 67.8\left(3^{\prime}\right), 71.3(7), 80.8\left(2^{\prime}\right), 81.9\left(4^{\prime}\right)$, $90.1\left(1^{\prime}\right), 96.1(5), 117.2(9), 127.5,128.9$ (Ar.), 133.0 (8, Ar.), 134.4 (6), 144.4 (2), 162.2 (4). IR (film; $\mathrm{NaCl}) \vee 2946,2868,1699,1667$, $1620,1553,1488,1264,1126,1040,886 \mathrm{~cm}^{-1}$. FAB MS (3-NBA) $m / z 630\left(\mathrm{M}^{+}+1\right)$. 
3',5'-O-(Tetraisopropyldisiloxane-1,3-diyl)2'-O-(2,3-dihydroxypropyl)cytidine (S.12). TLC $\left(19: 1 \mathrm{CH}_{2} \mathrm{Cl}_{2} / \mathrm{CH}_{3} \mathrm{OH}\right) R_{\mathrm{f}}=0.23 ;{ }^{1} \mathrm{H}$ NMR $\left(360 \mathrm{MHz}, \mathrm{CDCl}_{3}\right.$ ) $\delta$ (two diastereomers) $0.98-1.11\left(28 \mathrm{H}, \mathrm{m}, 4\left(\mathrm{CH}_{3}\right)_{2}\right) \mathrm{CHSi}, 4$ $\left.\left.\left(\mathrm{CH}_{3}\right)_{2}\right) \mathrm{CHSi}\right), 3.66(1 \mathrm{H}, \mathrm{dd}, J=5.2,10.7 \mathrm{~Hz}$, $\left.\mathrm{CH}(\mathrm{OH}) \mathrm{CH}_{2 \mathrm{a}} \mathrm{OH}\right), \quad 3.72-3.76 \quad(2 \mathrm{H}, \quad \mathrm{m}$, $\left.\mathrm{CH}_{2} \mathrm{CH}(\mathrm{OH}) \mathrm{CH}_{2}, \mathrm{CH}(\mathrm{OH}) \mathrm{CH}_{2 \mathrm{~b}} \mathrm{OH}\right), 3.88$ $4.06\left(4 \mathrm{H}, \mathrm{m}, 2^{\prime}, 5^{\prime}, \mathrm{OCH}_{2} \mathrm{CH}(\mathrm{OH})\right), 4.15-4.28$ $\left(2 \mathrm{H}, \mathrm{m}, 3^{\prime}, 4^{\prime}\right), 4.30\left(1 \mathrm{H}, \mathrm{d}, J=13.5 \mathrm{~Hz}, 5^{\prime \prime}\right)$, $5.83\left(1 \mathrm{H}, \mathrm{s}, 1^{\prime}\right), 7.49-7.63(4 \mathrm{H}, \mathrm{m}, 5, \mathrm{Ar})$, 7.90-7.92 (2H, m, Ar), 8.31-8.34 (1H, m, 6), $8.94\left(1 \mathrm{H}\right.$, br s, NH). ${ }^{13} \mathrm{C}$ NMR $(90 \mathrm{MHz}$, $\left.\mathrm{CDCl}_{3}\right) \delta$ (two diastereomers) $12.5,12.6$, $12.9,13.0\left(\left(\mathrm{CH}_{3}\right)_{2} \mathrm{CHSi}\right), 16.8,16.9,17.0$, 17.3, 17.4, 17.4, $17.6\left(\left(\mathrm{CH}_{2} \mathrm{CHSi}\right), 59.2\right.$ $\left(5^{\prime}\right)$, 63.6, $63.9\left(\mathrm{CH}(\mathrm{OH}) \mathrm{CH}_{2} \mathrm{OH}\right), 67.8\left(3^{\prime}\right)$, $70.4,70.5\left(\mathrm{OCH}_{2} \mathrm{CH}(\mathrm{OH})\right), 73.4,74.3$ (CH3) $\left.2 \mathrm{CH}(\mathrm{OH}) \mathrm{CH}_{2}\right), 82.0\left(2^{\prime}\right), 83.1,83.3$ (4'), 89.9, $90.2\left(1^{\prime}\right), 96.3$ (5), 127.6, 129.0, 132.8 (Ar), 133.3 (6), 144.3 (2), 162.5 (4). IR (film; NaCl) v 3367, 2946, 2868, 1700, 1655, 1617, 1486, 1257, 1126, 1040, 886, $704 \mathrm{~cm}^{-1}$. MS (FAB, 3-NBA) $\mathrm{m} / z 664\left(\mathrm{M}^{+}\right.$ $+1)$.

3',5'-O-(Tetraisopropyldisiloxane-1,3-diyl)$N^{4}$-(benzoyl)-2'-O-(ethanal)cytidine (S.13). TLC (37:3 $\left.\mathrm{CH}_{2} \mathrm{Cl}_{2} / \mathrm{CH}_{3} \mathrm{OH}\right) R_{\mathrm{f}}=0.50 ;{ }^{1} \mathrm{H}$ NMR (360 MHz, CDCl3) $\delta$ 0.98-1.11 (28H, m, 4 $\left.\left(\mathrm{CH}_{3}\right)_{2} \mathrm{CHSi}, 4\left(\mathrm{CH}_{3}\right)_{2} \mathrm{CHSi}\right), 3.98-4.07(2 \mathrm{H}$, $\left.\mathrm{m}, 2^{\prime}, 5^{\prime}\right), 4.18-4.31\left(3 \mathrm{H}, \mathrm{m}, 3^{\prime}, 4^{\prime}, 5^{\prime \prime}\right), 4.47-$ $4.59\left(2 \mathrm{H}, \mathrm{m}, \mathrm{OCH}_{2} \mathrm{CHO}\right), 5.86\left(1 \mathrm{H}, \mathrm{s}, 1^{\prime}\right)$, 7.49-7.63 (4H, m, 5, Ar), 7.89-7.91 (2H, m, Ar), $8.37(1 \mathrm{H}, \mathrm{d}, J=7.5 \mathrm{~Hz}, 6), 8.81(1 \mathrm{H}, \mathrm{br} \mathrm{s}, \mathrm{N} H)$, $9.81\left(1 \mathrm{H}, \mathrm{s}, \mathrm{CH}_{2} \mathrm{CHO}\right) .{ }^{13} \mathrm{C} \mathrm{NMR}(90 \mathrm{MHz}$, $\left.\mathrm{CDCl}_{3}\right) \delta 12.3,12.9,13.0,13.4\left(\left(\mathrm{CH}_{3}\right)_{2} \mathrm{CHSi}\right)$, 16.7, 16.9, 17.3, $17.4\left(\left(\mathrm{CH}_{3}\right)_{2} \mathrm{CHSi}\right), 59.2\left(5^{\prime}\right)$, $68.1\left(^{\prime}\right), 76.2\left(\mathrm{OCH}_{2} \mathrm{CHO}\right), 81.8\left(2^{\prime}\right), 83.0\left(4^{\prime}\right)$, 89.7 (1'), 96.2 (5), 127.5, 129.0, 132.8 (Ar), 133.2 (6), 144.3 (2), 162.4 (4), 200.7 $\left(\mathrm{CH}_{2} \mathrm{CHO}\right.$ ). IR (film; $\left.\mathrm{NaCl}\right) \vee 2946,2868$, 1700, 1667, 1619, 1484, 1253, 1130, 1064, $1040,886,703 \mathrm{~cm}^{-1}$. MS (FAB, 3-NBA) $\mathrm{m} / \mathrm{z}$ $632\left(\mathrm{M}^{+}+1\right)$.

3',5'-O-(Tetraisopropyldisiloxane-1,3-diyl)$\mathrm{N}^{4}$-(benzoyl)-2'-O-(2-hydroxyethyl)cytidine (S.14). TLC (37:3 $\left.\mathrm{CH}_{2} \mathrm{Cl}_{2} / \mathrm{CH}_{3} \mathrm{OH}\right) R_{\mathrm{f}}=0.56$. ${ }^{1} \mathrm{HNMR}\left(360 \mathrm{MHz}, \mathrm{CDCl}_{3}\right) \delta 0.99-1.10(28 \mathrm{H}$, $\left.\mathrm{m}, 4\left(\mathrm{CH}_{3}\right)_{2} \mathrm{CHSi}, 4\left(\mathrm{CH}_{3}\right)_{2} \mathrm{CHSi}\right), 3.17(1 \mathrm{H}$, br s, $\left.\mathrm{CH}_{2} \mathrm{CH}_{2} \mathrm{OH}\right), 3.72-3.77(2 \mathrm{H}, \mathrm{m}$, $\left.\mathrm{CH}_{2} \mathrm{CH}_{2} \mathrm{OH}\right), 3.93-4.03\left(4 \mathrm{H}, \mathrm{m}, 2^{\prime}, 5^{\prime}\right.$, $\left.\mathrm{OCH}_{2} \mathrm{CH}_{2} \mathrm{OH}\right), 4.15-4.25$ (2H, m, 3', 4'), 4.30 $\left(1 \mathrm{H}, \mathrm{d}, J=13.6 \mathrm{~Hz}, 5^{\prime \prime}\right), 5.83\left(1 \mathrm{H}, \mathrm{s}, 1^{\prime}\right)$, 7.49-7.63 (4H, m, 5, Ar), 7.89-7.92 (2H, m, Ar), $8.35(1 \mathrm{H}, \mathrm{d}, J=7.5 \mathrm{~Hz}, 6), 8.92(1 \mathrm{H}, \mathrm{br}$ $\mathrm{s}, \mathrm{N} H) .{ }^{13} \mathrm{C} \mathrm{NMR}\left(90 \mathrm{MHz}, \mathrm{CDCl}_{3}\right) \delta 12.6$, 12.9, 13.0, $13.4\left(\left(\mathrm{CH}_{3}\right)_{2} \mathrm{CHSi}\right), 16.8,16.9$,
17.0, 17.3, 17.4, 17.4 (( $\left.\left.\mathrm{CH}_{3}\right)_{2} \mathrm{CHSi}\right), 59.3\left(5^{\prime}\right)$, $61.7 \quad\left(\mathrm{CH}_{2} \mathrm{CH}_{2} \mathrm{OH}\right), \quad 68.0 \quad\left(3^{\prime}\right), \quad 73.1$ $\left(\mathrm{OCH}_{2} \mathrm{CH}_{2} \mathrm{OH}\right), 82.0\left(2^{\prime}\right), 82.3\left(4^{\prime}\right), 90.5$ (1'), 96.2 (5), 127.5, 129.0, 132.9 (Ar), 133.2 (6), 144.3 (2), 162.4 (4). IR (film; NaCl) v 2946, 2868, 1699, 1664, 1619, 1485, 1263, 1128, 1074, 1063, 1040, 886, $703 \mathrm{~cm}^{-1}$. MS (FAB, 3-NBA) $\mathrm{m} / \mathrm{z} 634\left(\mathbf{M}^{+}+1\right)$.

$3^{\prime}, 5^{\prime}$-O-(Tetraisopropyldisiloxane-1,3-diyl)$\mathrm{N}^{4}$-(benzoyl)-2'-O-(ethyl-2-methylsul- fonate)cytidine (S.15). TLC (19:1 $\mathrm{CH}_{2} \mathrm{Cl}_{2} /$ $\left.\mathrm{CH}_{3} \mathrm{OH}\right) R_{\mathrm{f}}=0.35 .{ }^{1} \mathrm{H}$ NMR $(360 \mathrm{MHz}$, $\left.\mathrm{CDCl}_{3}\right) \delta$ 0.97-1.11 (28H, m, $4\left(\mathrm{CH}_{3}\right)_{2} \mathrm{CHSi}, 4$ $\left.\left(\mathrm{CH}_{3}\right)_{2} \mathrm{CHSi}\right), 3.14\left(3 \mathrm{H}, \mathrm{s}, \mathrm{CH}_{3} \mathrm{SO}_{2}\right), 3.97-4.01$ $\left(2 \mathrm{H}, \mathrm{m}, 2^{\prime}, 5^{\prime}\right), 4.17-4.21\left(4 \mathrm{H}, \mathrm{m}, 3^{\prime}, 4^{\prime}\right.$, $\left.\mathrm{OCH}_{2} \mathrm{HH}_{2} \mathrm{OSO}_{2}\right), 4.30\left(1 \mathrm{H}, \mathrm{d}, J=13.7 \mathrm{~Hz}, 5^{\prime \prime}\right)$, 4.46-4.49 $\left(2 \mathrm{H}, \mathrm{m}, \mathrm{CH}_{2} \mathrm{CH}_{2} \mathrm{OSO}_{2}\right), 5.82(1 \mathrm{H}, \mathrm{s}$, $\left.1^{\prime}\right), 7.50-7.62(4 \mathrm{H}, \mathrm{m}, 5, \mathrm{Ar}), 7.89-7.92(2 \mathrm{H}, \mathrm{m}$, Ar), $8.38(1 \mathrm{H}, \mathrm{d}, J=7.5 \mathrm{~Hz}, 6) .{ }^{13} \mathrm{C}$ NMR $(90$ $\left.\mathrm{MHz}, \mathrm{CDCl}_{3}\right) \delta 12.4,12.9,13.1,13.4$ $\left(\left(\mathrm{CH}_{3}\right)_{2} \mathrm{CHSi}\right), 16.8,16.9,17.1,17.3,17.4$, $17.4\left(\left(\mathrm{CH}_{3}\right)_{2} \mathrm{CHSi}\right), 37.80\left(\mathrm{CH}_{3} \mathrm{SO}_{2}\right), 59.3\left(5^{\prime}\right)$, 67.9 (3'), $69.0\left(\mathrm{CH}_{2} \mathrm{CH}_{2} \mathrm{OSO}_{2}\right), 69.5\left(\mathrm{OCH}_{2}\right.$ $\mathrm{CH}_{2} \mathrm{OSO}_{2}$ ), 81.9 (2'), $82.4\left(4^{\prime}\right), 89.5$ (1'), 96.2 (5), 127.6, 129.1, 132.8 (Ar), 133.3 (6), 144.5 (2), 162.4 (4). IR (film; NaCl) v 2945, 2868 , 1664, 1484, 1170, 1128, 1074, 1063, 1040, $885,704 \mathrm{~cm}^{-1} \mathrm{MS}$ (FAB, 3-NBA) $\mathrm{m} / \mathrm{z} 712\left(\mathrm{M}^{+}\right.$ $+1)$.

$3^{\prime}, 5^{\prime}-O$-(Tetraisopropyldisiloxane-1,3-diyl)$\mathrm{N}^{4}$-(benzoyl)-2'-O-(thiobenzoylethyl) cytidine (S.16). TLC $(6: 3: 1$ petroleum ether $\left./ \mathrm{EtOAc} / \mathrm{CH}_{3} \mathrm{CN}\right) R_{\mathrm{f}}=0.57 .{ }^{1} \mathrm{H}$ NMR $(360$ $\left.\mathrm{MHz}, \mathrm{CDCl}_{3}\right) \delta$ 0.98-1.11 $(28 \mathrm{H}, \mathrm{m}, 4$ $\left.\left(\mathrm{CH}_{3}\right)_{2} \mathrm{CHSi}, 4\left(\mathrm{CH}_{3}\right)_{2} \mathrm{CHSi}\right), 3.35-3.43(2 \mathrm{H}$, $\left.\mathrm{m}, \mathrm{CH}_{2} \mathrm{CH}_{2} \mathrm{SBz}\right), 3.97-4.02\left(2 \mathrm{H}, \mathrm{m}, 2^{\prime}, 5^{\prime}\right)$, 4.09-4.13 $\left(2 \mathrm{H}, \mathrm{m}, \mathrm{OCH}_{2} \mathrm{CH}_{2} \mathrm{SBz}\right), 4.18(1 \mathrm{H}$, $\left.\mathrm{dd}, J=3.9,9.6 \mathrm{~Hz}, 3^{\prime}\right), 4.25(1 \mathrm{H}, \mathrm{dd}, J=2.0$, $\left.9.6 \mathrm{~Hz}, 4^{\prime}\right), 4.30\left(1 \mathrm{H}, \mathrm{d}, J=13.5 \mathrm{~Hz}, 5^{\prime \prime}\right), 5.84$ $\left(1 \mathrm{H}, \mathrm{s}, 1^{\prime}\right), 7.40-7.62(7 \mathrm{H}, \mathrm{m}, 5, \mathrm{Ar}), 7.91-7.99$ $(4 \mathrm{H}, \mathrm{m}, \mathrm{Ar}), 8.37(1 \mathrm{H}, \mathrm{d}, J=7.4 \mathrm{~Hz}, 6), 8.97$ $(1 \mathrm{H}$, br s, $\mathrm{NH}) .{ }^{13} \mathrm{C}$ NMR $\left(90 \mathrm{MHz}, \mathrm{CDCl}_{3}\right) \delta$ $12.5,12.8,13.1,13.4\left(\left(\mathrm{CH}_{3}\right)_{2} \mathrm{CHSi}\right), 16.8$, 16.9, 17.1, 17.3, 17.4, $17.5\left(\left(\mathrm{CH}_{3}\right)_{2} \mathrm{CHSi}\right), 29.1$ $\left(\mathrm{CH}_{2} \mathrm{CH}_{2} \mathrm{SBz}\right), 59.4$ (5'), 67.9 (3'), 69.9 $\left(\mathrm{OCH}_{2} \mathrm{CH}_{2} \mathrm{SBz}\right.$ ), 81.8 (2'), 81.9 (4'), 90.0 (1'), 96.0(5), 127.2, 127.6, 128.5, 129.0,133.0(Ar), 133.2 (6), 137.1 (Ar), 144.6 (2), 162.3 (4), 191.5 (Ar). IR (film; $\mathrm{NaCl}$ ) $2945,2868,1699$, 1667, 1620, 1489, 1373, 1265, 1126, 1075, 1063, 1040, $691 \mathrm{~cm}^{-1}$. EI MS m/z $754\left(\mathrm{M}^{+}+\right.$ 1).

$N^{4}$-(Benzoyl)-2'-O-(thiobenzoylethyl)cytidine (S.17). TLC (19:1 $\left.\mathrm{CH}_{2} \mathrm{Cl}_{2} / \mathrm{CH}_{3} \mathrm{OH}\right) R_{\mathrm{f}}=0.21$. ${ }^{1} \mathrm{H} \mathrm{NMR}\left(360 \mathrm{MHz}, \mathrm{CDCl}_{3}\right) \delta 3.25-3.42(2 \mathrm{H}$, $\left.\mathrm{m}, \mathrm{CH}_{2} \mathrm{SBz}\right), 3.91-3.96$ (2H, m, 2', 5'), 4.054.19 (3H, m, 5", $\left.\mathrm{OCH}_{2} \mathrm{CH}_{2} \mathrm{SBz}\right), 4.20-4.25$
Methods for Cross-Linking Nucleic Acids 
$\left(1 \mathrm{H}, \mathrm{m}, 4^{\prime}\right), 4.35-4.37\left(1 \mathrm{H}, \mathrm{m}, 3^{\prime}\right), 5.87(1 \mathrm{H}, \mathrm{s}$, $\left.1^{\prime}\right)$, 7.33-7.54 (7H, m, 5, Ar), 7.82-7.94 (4H, m, $\mathrm{Ar}), 8.57(1 \mathrm{H}, \mathrm{d}, J=7.5 \mathrm{~Hz}, 6), 9.22(1 \mathrm{H}, \mathrm{br} \mathrm{s}$, $\mathrm{N} H) .{ }^{13} \mathrm{C}$ NMR $\left(90 \mathrm{MHz}, \mathrm{CDCl}_{3}\right) \delta 28.8$ $\left(\mathrm{CH}_{2} \mathrm{SBz}\right), \quad 59.8 \quad\left(5^{\prime}\right), 67.4 \quad\left(3^{\prime}\right), 69.4$ $\left(\mathrm{OCH}_{2} \mathrm{CH}_{2} \mathrm{SBz}\right), 82.0\left(2^{\prime}\right), 84.6\left(4^{\prime}\right), 90.1\left(1^{\prime}\right)$, 96.7 (5), 126.8, 127.2, 127.6, 128.3, 128.6, 128.8, 132.9, 133.1 (Ar), $133.5(6), 136.7(\mathrm{Ar})$, 146.0 (2), 162.6 (4), 191.4 (Ar). IR (film; $\mathrm{NaCl})$ v 3345, 2928, 1699, 1658, 1617, 1558, 1485, 1379, 1258, 1111, 1067, 913, 705, $689 \mathrm{~cm}^{-1}$. MS (FAB, 3-NBA) $m / z 512\left(\mathbf{M}^{+}+1\right)$.

$N^{4}$-(Benzoyl)-2'-O-(ethyl)cytidine tert-butyl disulfide (S.18). TLC (24:1 $\quad \mathrm{CH}_{2} \mathrm{Cl}_{2} /$ $\left.\mathrm{CH}_{3} \mathrm{OH}\right) R_{\mathrm{f}}=0.29 ;{ }^{1} \mathrm{H}$ NMR $(360 \mathrm{MHz}$, $\left.\mathrm{CDCl}_{3}\right) \delta 1.32\left(9 \mathrm{H}, \mathrm{s}, \mathrm{C}\left(\mathrm{CH}_{3}\right)_{3}\right), 2.93(2 \mathrm{H}, \mathrm{t}, J$ $=5.8 \mathrm{~Hz}, \mathrm{CH}_{2} \mathrm{SS}$ ), 3.93-3.99 (2H, m, 2', 5'), 4.09-4.18 (3H, m, 5", $\left.\mathrm{OCH}_{2} \mathrm{CH}_{2} \mathrm{SS}\right), 4.24-4.30$ $\left(1 \mathrm{H}, \mathrm{m}, 4^{\prime}\right), 4.33-4.41\left(1 \mathrm{H}, \mathrm{m}, 3^{\prime}\right), 5.84(1 \mathrm{H}, \mathrm{d}$, $\left.J=1.7 \mathrm{~Hz}, 1^{\prime}\right), 7.48-7.62(4 \mathrm{H}, \mathrm{m}, 5, \mathrm{Ar})$, 7.87-7.89 (2H, m, Ar), $8.48(1 \mathrm{H}, \mathrm{d}, J=7.5 \mathrm{~Hz}$, 6), $9.01\left(1 \mathrm{H}\right.$, br s, NH). ${ }^{13} \mathrm{C}$ NMR $(90 \mathrm{MHz}$, $\left.\mathrm{CDCl}_{3}\right) \delta 29.8\left(\mathrm{C}\left(\mathrm{CH}_{3}\right)_{3}\right), 40.3\left(\mathrm{CH}_{2} \mathrm{SS}\right), 48.0$ $\left(C\left(\mathrm{CH}_{3}\right)_{3}\right), \quad 60.3 \quad\left(5^{\prime}\right), 67.8 \quad\left(3^{\prime}\right), 69.0$ $\left(\mathrm{OCH}_{2} \mathrm{CH}_{2} \mathrm{SS}\right), 81.7\left(2^{\prime}\right), 85.0$ (4'), 90.9 (1'), 96.7 (5), 127.6, 129.0, 132.9 (Ar), 133.3 (6), 146.4 (2), 162.5 (4). IR (film; NaCl) v 3374 , 2960, 2922, 1699, 1648, 1617, 1558, 1487, $1379,1260,1110 \mathrm{~cm}^{-1}$. FAB MS (3-NBA) $\mathrm{m} / z$ $496\left(\mathrm{M}^{+}+1\right)$.

$5^{\prime}-O$-(4, 4'-Dimethoxytrityl)- $\left.N^{4}\right)$-benzoyl)$2^{\prime}$ - $O$-(ethyl)cytidine tert-butyl disulfide (S.19). TLC (1:1 acetone/petroleum ether) $R_{\mathrm{f}}=0.23$; ${ }^{1} \mathrm{H}$ NMR $\left(360 \mathrm{MHz}, \mathrm{CD}_{3} \mathrm{CN}\right) \delta 1.30(9 \mathrm{H}, \mathrm{s}$, $\left.\mathrm{C}\left(\mathrm{CH}_{3}\right)_{3}\right), 2.95\left(2 \mathrm{H}, \mathrm{t}, J=6.3 \mathrm{~Hz}, \mathrm{CH}_{2} \mathrm{SS}\right)$, 3.39-3.44 (2H, m, $\left.\mathrm{OCH}_{2} \mathrm{CH}_{2} \mathrm{SS}\right), 3.76(6 \mathrm{H}, \mathrm{s}$, $\left.2 \mathrm{OCH}_{3}\right), 3.90-4.03\left(3 \mathrm{H}, \mathrm{m}, 2^{\prime}, 5^{\prime}, 5^{\prime \prime}\right), 4.12-$ $4.19\left(1 \mathrm{H}, \mathrm{m}, 4^{\prime}\right), 4.39-4.47\left(1 \mathrm{H}, \mathrm{m}, 3^{\prime}\right), 5.84$ $\left(1 \mathrm{H}, \mathrm{d}, J=1.7 \mathrm{~Hz}, 1^{\prime}\right), 6.87-6.89(4 \mathrm{H}, \mathrm{m}, \mathrm{Ar})$, 7.15-7.61 (13H, m, 5, Ar), 7.92-7.95 (2H, m, Ar), $8.46(1 \mathrm{H}, \mathrm{d}, J=7.6 \mathrm{~Hz}, 6) .{ }^{13} \mathrm{C}$ NMR $(90$

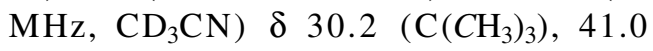
$\left(\mathrm{CH}_{2} \mathrm{SS}\right), 48.5\left(\mathrm{C}\left(\mathrm{CH}_{3}\right)_{3}\right), 56.0\left(\mathrm{OCH}_{3}\right), 62.1$ (5'), 68.9 (3'), $70.1\left(\mathrm{OCH}_{2} \mathrm{CH}_{2} \mathrm{SS}\right), 83.3$ (2'), $83.6\left(4^{\prime}\right), 87.7\left(\mathrm{OC}(\mathrm{Ph})_{3}\right), 90.2\left(1^{\prime}\right), 97.2(5)$, 114.3, 128.1, 129.1, 129.1, 129.2, 129.7, 131.0, 131.2, (Ar), 133.9 (6), 134.5, 136.6, 137.0, 145.5 (Ar), 145.9 (2), 155.7, 159.8 (Ar), 163.9 (4), 168.2 (Ar). IR (KBr) v 3392, 2959, 2924, 1700, 1667, 1610, 1553, 1510, 1482, 1377, $1252,1113,1033,704 \mathrm{~cm}^{-1}$. MS (FAB, 3NBA) $m / z 798\left(\mathbf{M}^{+}+1\right)$.

$5^{\prime}-O$-(4, 4'-Dimethoxytrityl)- $\left.N^{4}\right)$-benzoyl)$2^{\prime}$ - $O$-(ethyl)cytidine tert-butyl disulfide $3^{\prime}-O$ (N,N-diisopropyl $\beta$ cyanoethylphosphoramidite) (S.20). TLC (2:1 petroleum ether/acetone) $R_{\mathrm{f}}=0.40 ;{ }^{1} \mathrm{H}$ NMR $(300 \mathrm{MHz}$,
$\mathrm{CD}_{3} \mathrm{CN}$ ) $\delta$ (two diastereomers) $1.05-1.20$ $\left(12 \mathrm{H}, \mathrm{m}, 2 \mathrm{NCH}\left(\mathrm{CH}_{3}\right)_{2}\right), 1.30\left(9 \mathrm{H}, \mathrm{s}, \mathrm{C}\left(\mathrm{CH}_{3}\right)_{3}\right)$, 2.50-2.67 (2H, m, $\left.\mathrm{OCH}_{2} \mathrm{CH}_{2} \mathrm{CN}\right), 2.94-3.01$ $\left(2 \mathrm{H}, \mathrm{m}, \mathrm{CH}_{2} \mathrm{SS}\right), 3.41-3.71(6 \mathrm{H}, \mathrm{m}$, $\left.\mathrm{OCH}_{2} \mathrm{CH}_{2} \mathrm{SS}, \mathrm{OCH}_{2} \mathrm{CH}_{2} \mathrm{CN}, 2 \mathrm{NCH}\left(\mathrm{CH}_{3}\right)_{2}\right)$, $3.79\left(6 \mathrm{H}, \mathrm{s}, 2 \mathrm{OCH}_{3}\right), 3.80-4.22\left(4 \mathrm{H}, \mathrm{m}, 2^{\prime}, 4^{\prime}\right.$, $\left.5^{\prime}, 5^{\prime \prime}\right), 4.43-4.63(1 \mathrm{H}, \mathrm{m}, 3), 5.88\left(1 \mathrm{H}, \mathrm{s}, 1^{\prime}\right)$, 6.87-6.92 (4H, m, Ar), 7.03-7.66 (13H, m, 5, Ar), 7.91-7.97 (2H, m, Ar), 8.42-8.55 (1H, $2 \mathrm{~d}$, $J=7.6 \mathrm{~Hz}, 6) .{ }^{13} \mathrm{C}$ NMR $\left(75 \mathrm{MHz}, \mathrm{CD}_{3} \mathrm{CN}\right) \delta$ (two diastereomers) 21.2, $21.3\left(\mathrm{OCH}_{2}\right.$ $\left.\mathrm{CH}_{2} \mathrm{CN}\right), 24.9,25.0,25.2,25.3\left(\mathrm{NCH}\left(\mathrm{CH}_{3}\right)_{2}\right)$, $30.3\left(\mathrm{C}\left(\mathrm{CH}_{3}\right)_{3}\right), 41.4\left(\mathrm{CH}_{2} \mathrm{SS}\right), 44.1,44.3$ $\left(\mathrm{NCH}\left(\mathrm{CH}_{3}\right)_{2}\right), 48.5\left(\mathrm{C}\left(\mathrm{CH}_{3}\right)_{3}\right), 56.0\left(\mathrm{OCH}_{3}\right)$, 59.3, $59.6\left(\mathrm{OCH}_{2} \mathrm{CH}_{2} \mathrm{CN}\right), 61.8,62.2\left(5^{\prime}\right)$, 70.2, 70.4 (3'), $70.8\left(\mathrm{OCH}_{2} \mathrm{CH}_{2} \mathrm{SS}\right), 82.2\left(2^{\prime}\right)$, $83.1\left(4^{\prime}\right), 87.8\left(\mathrm{OC}(\mathrm{Ph})_{3}\right), 90.8,91.1\left(1^{\prime}\right), 97.3$ (5), 114.2, 128.1, 129.0, 129.0, 129.3, 129.6, 131.2 (Ar), 133.8 (6), 134.5, 136.6, 136.7, 145.4 (Ar), 145.6 (2), 155.4, 159.8 (Ar), 163.6 (4). ${ }^{31} \mathrm{P}$ NMR (202 MHz; $\left.\mathrm{CD}_{3} \mathrm{CN}\right) \delta 147.57$, 146.51. IR (film; NaCl) v 2967, 2934, 1708, 1686, 1509, 1510, 1462, 1251, 1180, 1035, 979 $\mathrm{cm}^{-1}$. MS (FAB, 3-NBA) $\mathrm{m} / 2.998\left(\mathrm{M}^{+}+1\right)$. Anal. Calcd for $\mathrm{C}_{52} \mathrm{H}_{64} \mathrm{~N}_{5} \mathrm{O}_{9} \mathrm{PS}_{2}: \mathrm{C}, 62.56 ; \mathrm{H}$, $6.48 ; \mathrm{N}, 7.02$. Found: C, $62.41 ; \mathrm{H}, 6.41 ; \mathrm{N}, 6.92$.

3',5'-O-(Tetraisopropyldisiloxane-1,3-diyl)$2^{\prime}$ - $O$-allyluridine (S.21). TLC (1:1 petroleum ether/EtOAc) $R_{\mathrm{f}} 0.59 ;{ }^{1} \mathrm{H}$ NMR $(360 \mathrm{MHz}$, $\left.\mathrm{CDCl}_{3}\right) \delta$ 1.01-1.11 (28H, m, isopropyl), 3.88 $\left(1 \mathrm{H}, \mathrm{m}, 4^{\prime}\right), 3.98\left(1 \mathrm{H}, \mathrm{dd}, \mathrm{OCH}_{2 \mathrm{a}}\right), 4.18(2 \mathrm{H}$, $\left.\mathrm{m}, 2^{\prime}, 3^{\prime}\right), 4.26\left(1 \mathrm{H}, \mathrm{dd}, \mathrm{OCH}_{2 \mathrm{~b}}\right), 4.39(2 \mathrm{H}, \mathrm{m}$, $\left.5^{\prime}, 5^{\prime \prime}\right), 5.21\left(1 \mathrm{H}, \mathrm{ddd},=\mathrm{CH}_{2 \mathrm{a}}\right), 5.40(1 \mathrm{H}, \mathrm{ddd}$, $\left.=\mathrm{CH}_{2 \mathrm{~b}}\right), 5.68(1 \mathrm{H}, \mathrm{dd}, 5), 5.76\left(1 \mathrm{H}, \mathrm{s}, 1^{\prime}\right), 5.93$ $(1 \mathrm{H}, \mathrm{m}, \mathrm{CH}=), 7.93(1 \mathrm{H}, \mathrm{d}, 6), 9.14(1 \mathrm{H}, \mathrm{s}, \mathrm{NH})$; ${ }^{13} \mathrm{C}$ NMR $\left(90 \mathrm{MHz}, \mathrm{CDCl}_{3}\right.$ ) $\delta$ 12.68-13.63 (isopropyl CHs), 17.00-17.70 (isopropyl $\left.\mathrm{CH}_{3} \mathrm{~s}\right), 59.62\left(5^{\prime}\right), 68.25\left(3^{\prime}\right), 71.46\left(\mathrm{OCH}_{2}\right)$, $81.27\left(2^{\prime}\right), 82.00\left(4^{\prime}\right), 89.29\left(1^{\prime}\right), 101.69$ (5), $117.59\left(=\mathrm{CH}_{2}\right), 134.51(\mathrm{CH}=), 139.77(6)$, 150.06 (2), 163.61 (4); MS (DCI, $\left.\mathrm{CH}_{4}\right) \mathrm{m} / z 527$ $\left(\mathrm{M}^{+}\right)$.

$3^{\prime}, 5^{\prime}-O$-(Tetraisopropyldisiloxane-1,3-diyl)2'-O-(2,3-dihydroxypropyl)uridine (S.22). TLC $\left(51: 4 \mathrm{CH}_{2} \mathrm{Cl}_{2} / \mathrm{CH}_{3} \mathrm{OH}\right) R_{\mathrm{f}}=0.22 ;{ }^{1} \mathrm{H}$ NMR $\left(360 \mathrm{MHz}, \mathrm{CDCl}_{3}\right) \delta 1.02-1.10(28 \mathrm{H}, \mathrm{m}$, $\left.4 \mathrm{SiCH}\left(\mathrm{CH}_{3}\right)_{2}\right), \quad 3.65-3.75(3 \mathrm{H}, \mathrm{m}$, $\left.\mathrm{CH}_{2} \mathrm{CH}(\mathrm{OH}) \mathrm{CH}_{2} \mathrm{OH}, \mathrm{CH}_{2} \mathrm{CH}(\mathrm{OH}) \mathrm{CH}_{2} \mathrm{OH}\right)$, 3.86-4.04 (4H, m, 2', 5", $\mathrm{CH}_{2} \mathrm{CH}(\mathrm{OH})$ $\left.\mathrm{CH}_{2} \mathrm{OH}\right), 4.12-4.17\left(2 \mathrm{H}, \mathrm{m}, 3^{\prime}, 4^{\prime}\right), 4.25(1 \mathrm{H}$, $\left.\mathrm{d}, J=13.6 \mathrm{~Hz}, 5^{\prime}\right), 5.71(1 \mathrm{H}, \mathrm{dd}, J=1.4,8.1$ $\mathrm{Hz}, 5), 5.74\left(1 \mathrm{H}, \mathrm{d}, J=1.6 \mathrm{~Hz}, 1^{\prime}\right), 7.88(1 \mathrm{H}$, $\mathrm{dd}, J=1.9,8.1 \mathrm{~Hz}, 6) .{ }^{13} \mathrm{C}$ NMR $(75 \mathrm{MHz}$, $\left.\mathrm{CDCl}_{3}\right) \delta$ 13.07-13.90 $\left(\mathrm{SiCH}\left(\mathrm{CH}_{3}\right)_{2}\right), 17.18-$ $17.82\left(\mathrm{SiCH}\left(\mathrm{CH}_{3}\right)_{2}\right), 59.66\left(5^{\prime}\right), 68.58\left(3^{\prime}\right)$, $70.94\left(\mathrm{CH}_{2} \mathrm{CH}(\mathrm{OH}) \mathrm{CH}_{2} \mathrm{OH}\right), 74.20\left(\mathrm{CH}_{2} \mathrm{CH}\right.$ $\left.(\mathrm{OH}) \mathrm{CH}_{2} \mathrm{OH}\right), 82.22\left(4^{\prime}\right), 83.99\left(\mathrm{CH}_{2} \mathrm{CH}\right.$ 
$\left.(\mathrm{OH}) \mathrm{CH}_{2} \mathrm{OH}\right), 89.43\left(1^{\prime}\right), 89.67\left(2^{\prime}\right), 102.33$ (5), 139.24 (6), 150.82 (2), 163.33 (4). IR (Nujol) v 3424, 3160, 3092, 2951, 2946, 2935, 2925, 2918, 2909, 2896, 2891, 2873, 2867, 2863, 2856, 2850, 2726, 1693, 1685, 1462, $1378,1272,1163,1125,1062,1035,1010$, $991,884,703 \mathrm{~cm}^{-1}$.

3',5'-O-(Tetraisopropyldisiloxane-1,3-diyl)$2^{\prime}$ - $O$-(ethanal)uridine (S.23) TLC $\quad(51: 5$ $\left.\mathrm{CH}_{2} \mathrm{Cl}_{2} / \mathrm{CH}_{3} \mathrm{OH}\right) R_{\mathrm{f}}=0.48 ;{ }^{1} \mathrm{H}$ NMR $(300$ $\left.\mathrm{MHz} \mathrm{CDCl}_{3}\right) \delta$ 1.03-1.12 (28 H, m, 4 $\left.\mathrm{SiCH}\left(\mathrm{CH}_{3}\right)_{2}\right), 3.71\left(2 \mathrm{H}, \mathrm{s}, \mathrm{OCH}_{2} \mathrm{CHO}\right), 3.95-$ $4.01\left(2 \mathrm{H}, \mathrm{m}, 2^{\prime}, 5^{\prime \prime}\right), 4.23-4.30\left(2 \mathrm{H}, \mathrm{m}, 3^{\prime}, 4^{\prime}\right)$, 4.45-4.47 (1 H, m, $\left.5^{\prime}\right), 5.70$ ( $1 \mathrm{H}, \mathrm{dd}, J=2.2$, $8.1 \mathrm{~Hz}, 5), 5.78\left(1 \mathrm{H}, \mathrm{s}, 1^{\prime}\right), 7.90(1 \mathrm{H}, \mathrm{d}, J=$ $8.1 \mathrm{~Hz}, 6), 8.93$ (1 H, s, NH). ${ }^{13} \mathrm{C} \mathrm{NMR} \mathrm{(75}$ $\left.\mathrm{MHz}, \mathrm{CDCl}_{3}\right) \delta$ 12.87-13.82 $\left(\mathrm{SiCH}\left(\mathrm{CH}_{3}\right)_{2}\right)$, 17.11-17.78 $\left(\mathrm{SiCH}\left(\mathrm{CH}_{3}\right)_{2}\right), 59.64\left(5^{\prime}\right), 68.95$ (3'), $76.62\left(\mathrm{OCH}_{2} \mathrm{CHO}\right), 82.00\left(4^{\prime}\right), 83.85\left(2^{\prime}\right)$, $89.32\left(1^{\prime}\right), 102.03$ (5), 139.41 (6), 150.18 (2), 163.21 (4), $200.35\left(\mathrm{OCH}_{2} \mathrm{CHO}\right)$. IR (KBr) v 3482, 2947, 2868, 1700, 1685, 1464, 1386, 1272 , 1256, 1166, 1131, 1096, 1063, 1056, $1038,1012,991,886,704 \mathrm{~cm}^{-1}$.

$3^{\prime}, 5^{\prime}-O$-(Tetraisopropyldisiloxane-1,3-diyl)2'-O-(2-hydroxyethyl)uridine (S.24). TLC (6:3:1 petroleum ether/EtOAc/ $\left.\mathrm{CH}_{3} \mathrm{CN}\right) R_{\mathrm{f}}=$ $0.34 ;{ }^{1} \mathrm{H}$ NMR $\left(360 \mathrm{MHz}, \mathrm{CDCl}_{3}\right) \delta 1.01-1.10$ $\left(28 \mathrm{H}, \mathrm{m}, 4 \mathrm{SiCH}\left(\mathrm{CH}_{3}\right)_{2}\right), 3.74-3.76(2 \mathrm{H}, \mathrm{m}$, $\left.\mathrm{CH}_{2} \mathrm{CH}_{2} \mathrm{OH}\right), 3.92-4.00$ (4H, m, 2', 5', $\left.\mathrm{CH}_{2} \mathrm{CH}_{2} \mathrm{OH}\right), 4.17\left(2 \mathrm{H}, \mathrm{m}, 3^{\prime}, 4^{\prime}\right), 4.26(1 \mathrm{H}, \mathrm{d}$, $\left.J=13.7 \mathrm{~Hz}, 5^{\prime}\right), 5.70(1 \mathrm{H}, \mathrm{d}, J=8.1 \mathrm{~Hz}, 5)$, $5.75\left(1 \mathrm{H}, \mathrm{s}, 1^{\prime}\right), 7.90(1 \mathrm{H}, \mathrm{d}, J=8.1 \mathrm{~Hz}, 6), 9.96$ $(1 \mathrm{H}, \mathrm{s}, \mathrm{NH}) .{ }^{13} \mathrm{C} \mathrm{NMR}\left(90 \mathrm{MHz}, \mathrm{CDCl}_{3}\right) \delta$ 12.73-13.62 $\left(\mathrm{SiCH}\left(\mathrm{CH}_{3}\right)_{2}\right), 16.97-17.65$ $\left(\mathrm{SiCH}\left(\mathrm{CH}_{3}\right)_{2}\right), 59.46\left(5^{\prime}\right), 61.78\left(\mathrm{OCH}_{2}\right.$ $\left.\mathrm{CH}_{2} \mathrm{OH}\right), 68.37\left(3^{\prime}\right), 73.20\left(\mathrm{OCH}_{2} \mathrm{CH}_{2} \mathrm{OH}\right)$, $81.99\left(4^{\prime}\right), 83.04\left(2^{\prime}\right), 89.62\left(1^{\prime}\right), 101.99$ (5), 139.38 (6), 150.58 (2), 163.80 (4). IR (KBr) v 2946, 2869, 1701, 1464, 1387, 1271, 1165, 1129, 1094, 1062, 1039, 992, 885, $705 \mathrm{~cm}^{-1}$. $\operatorname{MS}\left(\mathrm{CI}, \mathrm{CH}_{4}\right) \mathrm{m} / z, 531\left(\mathrm{M}^{+}\right)$.

$3^{\prime}, 5^{\prime}-O$-(Tetraisopropyldisiloxane-1,3-diyl)$2^{\prime}$-O-(ethyl-2-methylsulfonate)uridine (S.25) TLC (17:3 $\mathrm{CH}_{2} \mathrm{Cl}_{2} /$ acetone) $R_{\mathrm{f}}=0.48 ;{ }^{1} \mathrm{HNMR}$ $\left(360 \mathrm{MHz}, \mathrm{CDCl}_{3}\right) \delta 1.03-1.12(28 \mathrm{H}, \mathrm{m}, 4$ $\left.\mathrm{SiCH}\left(\mathrm{CH}_{3}\right)_{2}\right), 3.12\left(3 \mathrm{H}, \mathrm{s}, \mathrm{SCH}_{3}\right), 3.89(1 \mathrm{H}, \mathrm{d}$, $\left.J=4.1 \mathrm{~Hz}, 2^{\prime}\right), 3.97(1 \mathrm{H}, \mathrm{dd}, J=2.2,13.6 \mathrm{~Hz}$, $\left.5^{\prime}\right)$, 4.10-4.15 (3H, m, 4', $\left.\mathrm{OCH}_{2} \mathrm{CH}_{2} \mathrm{~S}\right), 4.20$ $4.23\left(1 \mathrm{H}, \mathrm{m}, 3^{\prime}\right), 4.26$ (1H, d, $\left.J=13.6 \mathrm{~Hz}, 5^{\prime \prime}\right)$, 4.44-4.46 (2H, m, $\left.\mathrm{OCH}_{2} \mathrm{CH}_{2} \mathrm{~S}\right), 5.70(1 \mathrm{H}, \mathrm{dd}$, $J=2.1,8.2 \mathrm{~Hz}, 5), 5.73\left(1 \mathrm{H}, \mathrm{s}, 1^{\prime}\right), 7.91(1 \mathrm{H}$, $\mathrm{d}, J=8.2 \mathrm{~Hz}, 6), 8.95(1 \mathrm{H}, \mathrm{s}, \mathrm{NH}) .{ }^{13} \mathrm{C} \mathrm{NMR}$ $\left(75 \quad \mathrm{MHz}, \quad \mathrm{CDCl}_{3}\right) \quad \delta \quad 12.85-13.74$ $\left(\mathrm{SiCH}\left(\mathrm{CH}_{3}\right)_{2}\right), 17.07-17.73\left(\mathrm{SiCH}\left(\mathrm{CH}_{3}\right)_{2}\right)$, $38.00\left(\mathrm{SCH}_{3}\right), 59.59\left(5^{\prime}\right), 68.63\left(3^{\prime}\right), 69.29$ $\left(\mathrm{OCH}_{2} \mathrm{CH}_{2} \mathrm{OMs}\right), 69.44\left(\mathrm{OCH}_{2} \mathrm{CH}_{2} \mathrm{OMs}\right)$, $81.93\left(4^{\prime}\right), 83.27\left(2^{\prime}\right), 88.96\left(1^{\prime}\right), 101.97(5)$, 139.38 (6), 150.33 (2), 163.60 (4). IR (KBr) v 3213, 3065, 2947, 2869, 1699, 1465, 1355, 1272, 1179, 1129, 1095, 1065, 1040, 993, 885, $705 \mathrm{~cm}^{-1}$.

$3^{\prime}, 5^{\prime}-O$-(Tetraisopropyldisiloxane-1,3-diyl)$2^{\prime}$-O-(thiobenzoylethyl)uridine (S.26). TLC (4:1 $\mathrm{CH}_{2} \mathrm{Cl}_{2}$ /acetone) $R_{\mathrm{f}}=0.68 ;{ }^{1} \mathrm{H} \mathrm{NMR}(360$ $\left.\mathrm{MHz}, \mathrm{CDCl}_{3}\right) \delta 1.00-1.10(28 \mathrm{H}, \mathrm{m}, 4$ $\left.\mathrm{SiCH}\left(\mathrm{CH}_{3}\right)_{2}\right), 3.36\left(2 \mathrm{H}, \mathrm{m}, \mathrm{OCH}_{2} \mathrm{CH}_{2} \mathrm{~S}\right), 3.91$ $\left(1 \mathrm{H}, \mathrm{d}, J=3.3 \mathrm{~Hz}, 2^{\prime}\right), 3.99(1 \mathrm{H}, \mathrm{dd}, J=1.5$, $\left.13.6 \mathrm{~Hz}, 5^{\prime}\right)$, 4.02-4.06 (2H, m, $\left.\mathrm{OCH}_{2} \mathrm{CH}_{2} \mathrm{~S}\right)$, $4.18\left(2 \mathrm{H}, \mathrm{m}, 3^{\prime}, 4^{\prime}\right), 4.25(1 \mathrm{H}, \mathrm{d}, J=13.6 \mathrm{~Hz}$, $\left.5^{\prime \prime}\right), 5.68(1 \mathrm{H}, \mathrm{dd}, J=1.7,8.2 \mathrm{~Hz}, 5), 5.73(1 \mathrm{H}$, s, 1'), 7.44 (2H, m, Ar), 7.56 (1H, m, Ar), 7.90 $(1 \mathrm{H}, \mathrm{d}, J=8.2 \mathrm{~Hz}, 6), 7.96(1 \mathrm{H}, \mathrm{m}, \mathrm{Ar}), 9.47$ $(1 \mathrm{H}, \mathrm{s}, \mathrm{NH}) .{ }^{13} \mathrm{C} \mathrm{NMR}\left(90 \mathrm{MHz}, \mathrm{CDCl}_{3}\right) \delta$ 12.71-13.62 $\left(\mathrm{SiCH}\left(\mathrm{CH}_{3}\right)_{2}\right), 17.00-17.70$ $\left(\mathrm{SiCH}\left(\mathrm{CH}_{3}\right)_{2}\right), 29.16\left(\mathrm{OCH}_{2} \mathrm{CH}_{2} \mathrm{~S}\right), 59.57\left(5^{\prime}\right)$,

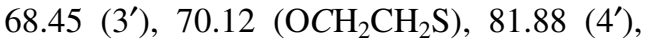
$82.60\left(2^{\prime}\right), 89.34\left(1^{\prime}\right), 101.71$ (5), 127.45, 128.74, 133.53, 137.18 (Ar), 139.73 (6), 150.14 (2), 163.92 (4), 191.67 (CO). IR (KBr) v 3205, 3058, 2945, 2868, 1699, 1463, 1387, 1271, 1207, 1164, 1126, 1093, 1064, 1040, $914,885,705,690 \mathrm{~cm}^{-1}$.

2'-O-(Thiobenzoylethyl)uridine (S.27). $\operatorname{TLC}\left(9: 1 \mathrm{CH}_{2} \mathrm{Cl}_{2} / \mathrm{CH}_{3} \mathrm{OH}\right) R_{\mathrm{f}}=0.14 ;{ }^{1} \mathrm{H} \mathrm{NMR}$ (360 MHz, $\left.\mathrm{CD}_{3} \mathrm{OD}\right) \delta$ 3.27-3.38 (2H, m, $\left.\mathrm{OCH}_{2} \mathrm{CH}_{2} \mathrm{~S}\right), 3.75(1 \mathrm{H}, \mathrm{dd}, J=3.0,12.4 \mathrm{~Hz}$, $\left.5^{\prime}\right)$, 3.82-3.96 (2H, m, 2', 5"), 3.99-4.02 (1H, $\left.\mathrm{m}, 4^{\prime}\right), 4.05-4.09\left(2 \mathrm{H}, \mathrm{m}, \mathrm{OCH}_{2} \mathrm{CH}_{2} \mathrm{~S}\right), 4.24$ $\left(1 \mathrm{H}, \mathrm{m}, 3^{\prime}\right), 5.67(1 \mathrm{H}, \mathrm{d}, J=8.1 \mathrm{~Hz}, 5), 5.95$ $\left(1 \mathrm{H}, \mathrm{d}, J=3.7 \mathrm{~Hz}, 1^{\prime}\right), 7.49$ (2H, m, ArH), 7.62 $(1 \mathrm{H}, \mathrm{m}, \mathrm{ArH}), 7.93(2 \mathrm{H}, \mathrm{m}, \mathrm{ArH}), 8.06(1 \mathrm{H}, \mathrm{d}$, $J=8.1 \mathrm{~Hz}, 6) .{ }^{13} \mathrm{C} \mathrm{NMR}\left(90 \mathrm{MHz}, \mathrm{CD}_{3} \mathrm{OD}\right)$ $\delta 29.70\left(\mathrm{OXH}_{2} \mathrm{CH}_{2} \mathrm{~S}\right), 61.77\left(5^{\prime}\right), 70.01$ (3'), $^{\prime}$, $70.65\left(\mathrm{OCH}_{2} \mathrm{CH}_{2} \mathrm{~S}\right), 83.80\left(4^{\prime}\right), 86.26\left(2^{\prime}\right)$,

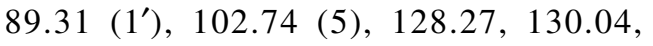
134.94, 138.30 (Ar), 142.58 (6), 152.35 (2), 166.36 (4), 193.18 (CO). IR (KBr) v 3473 , 3422, 3168, 3107, 3051, 2954, 2916, 2874, 2860, 2572, 2540, 1693, 1672, 1647, 1615, 1446, 1388, 1267, 1209, 1143, 1111, 1098, $915,770,687 \mathrm{~cm}^{-1}$. MS (CI, $\left.\mathrm{CH}_{4}\right) \mathrm{m} / z 409$ $\left(\mathrm{M}^{+}+1\right)$.

$5^{\prime}-O$-(4,4'-Dimethoxytrityl)-2'-O-(thiobenzoylethyl)uridine (S.28). TLC (19:1 $\left.\mathrm{CH}_{2} \mathrm{Cl}_{2} / \mathrm{CH}_{3} \mathrm{OH}\right) R_{\mathrm{f}}=0.59$. ${ }^{1} \mathrm{H}$ NMR $(360$ $\left.\mathrm{MHz}, \mathrm{CD}_{3} \mathrm{CN}\right) \delta 3.30-3.41$ (5H, m, 2', 5', 5', $\left.\mathrm{OCH}_{2} \mathrm{CH}_{2} \mathrm{~S}\right), 3.75$ (6H, s, $\left.2 \mathrm{OCH}_{3}\right), 3.87-3.99$ $\left(3 \mathrm{H}, \mathrm{m}, 4^{\prime}, \mathrm{OCH}_{2} \mathrm{CH}_{2} \mathrm{~S}\right)$ 4.01-4.04 (1H, m, 3'), $5.24(1 \mathrm{H}, \mathrm{d}, J=8.2 \mathrm{~Hz}, 5), 5.83(1 \mathrm{H}, \mathrm{d}, J=1.7$ $\left.\mathrm{Hz}, 1^{\prime}\right), 6.87$ (4H, m, ArH), 7.21-7.33 (9H, m, $\mathrm{ArH}), 7.41-7.52(5 \mathrm{H}, \mathrm{m}, \mathrm{ArH}), 7.61-7.66(1 \mathrm{H}$, $\mathrm{m}, \mathrm{ArH}), 7.74(1 \mathrm{H}, \mathrm{d}, J=8.2 \mathrm{~Hz}, 6), 7.93-7.96$ $(4 \mathrm{H}, \mathrm{m}, \mathrm{ArH}) .{ }^{13} \mathrm{C} \mathrm{NMR}\left(90 \mathrm{MHz}, \mathrm{CD}_{3} \mathrm{CN}\right) \delta$
Methods for Cross-Linking Nucleic Acids 
$17.03\left(\mathrm{OCH}_{2} \mathrm{CH}_{2} \mathrm{~S}\right), 56.02\left(\mathrm{OCH}_{3}\right), 63.11\left(5^{\prime}\right)$,

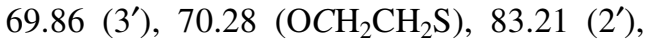
$84.04\left(4^{\prime}\right), 87.65\left(\mathrm{OC}(\mathrm{Ph})_{3}\right), 88.68\left(1^{\prime}\right), 102.55$ (5), 114.24 (Ar), 128.06, 129.02, 129.14, $129,98,131.17,131.64,134.81,136.49$, 136.73, 137.89 (Ar), 141.17 (6), 145.87 (Ar), 151.41 (2), 159.86 (Ar), 161.07 (4), 192.35 $(\mathrm{SC}(\mathrm{O}) \mathrm{Ph})$. MS (CI, $\left.\mathrm{CH}_{4}\right) \mathrm{m} / \mathrm{z} 710\left(\mathrm{M}^{+}\right)$.

$5^{\prime}$-O-(4,4'-Dimethoxytrityl)-2'-O-(ethyl)uridine tert-butyl disulfide (S.29) TLC (49:1 $\left.\mathrm{CH}_{2} \mathrm{Cl}_{2} / \mathrm{CH}_{3} \mathrm{OH}\right) R_{\mathrm{f}}=0.12 ;{ }^{1} \mathrm{H}$ NMR $(360$ $\mathrm{MHz}$, acetone-d $\left.{ }_{6}\right) \delta 1.32\left(9 \mathrm{H}, \mathrm{s}, \mathrm{C}\left(\mathrm{CH}_{3}\right)_{3}\right) 3.00$ $\left(2 \mathrm{H}, \mathrm{t}, J=6.5 \mathrm{~Hz}, \mathrm{OCH}_{2} \mathrm{CH}_{2} \mathrm{~S}\right), 3.48(2 \mathrm{H}, \mathrm{m}$, $\left.5^{\prime}, 5^{\prime \prime}\right), 3.80\left(6 \mathrm{H}, \mathrm{s}, \mathrm{OCH}_{3}\right), 3.94-4.07(4 \mathrm{H}, \mathrm{m}$, $\left.2^{\prime}, 3^{\prime}, \mathrm{OCH}_{2} \mathrm{CH}_{2} \mathrm{~S}\right), 4.15-4.17$ (1H, m 4'), 5.29 $(1 \mathrm{H}, \mathrm{d}, J=8.1 \mathrm{~Hz}, 5), 5.94(1 \mathrm{H}, \mathrm{d}, J=2.5 \mathrm{~Hz}$, $\left.1^{\prime}\right), 6.90-6.93(4 \mathrm{H}, \mathrm{m}, \mathrm{ArH}), 7.32-7.37$ (7H, m, $\mathrm{ArH}), 7.47-7.50(2 \mathrm{H}, \mathrm{m}, \mathrm{ArH}), 7.92(1 \mathrm{H}, \mathrm{d}, J$ $=8.1 \mathrm{~Hz}, 6) \cdot{ }^{13} \mathrm{C}$ NMR $\left(90 \mathrm{MHz}\right.$, acetone- $\left.\mathrm{d}_{6}\right)$ $\delta$ 29.28-30.56 (acetone, $\left.\mathrm{C}\left(\mathrm{CH}_{3}\right)_{3}\right), 40.79$ $\left(\mathrm{OCH}_{2} \mathrm{CH}_{2} \mathrm{~S}\right), 48.32\left(\mathrm{C} \quad\left(\mathrm{CH}_{3}\right)_{3}\right), 55.61$ $\left(\mathrm{OCH}_{3}\right), 63.15\left(5^{\prime}\right), 69.94\left(3^{\prime}\right), 70.16$ $\left(\mathrm{OCH}_{2} \mathrm{CH}_{2} \mathrm{~S}\right), 83.30\left(2^{\prime}\right), 84.03$ (4'), 87.58 (Ar), 88.75 (1'), 102.41 (5), 114.09, 127.83, $128.82,129.13,131.14,136.37,136.67$ (Ar), 140.88 (6), 145.93 (Ar), 151.29 (2), 159.80 (Ar), 163.58 (4). MS (FAB, 3-NBA) $m / z, 695$ $\left(\mathrm{M}^{+}+1\right)$.

3'- $O$-(N,N-Diisopropyl- $\beta$-cyanoethylphosphoramidite)-5'-O-(4,4'-dimethoxytrityl)-2$O$-(ethyl)uridine tert-butyl disulfide (S.30). TLC (2:1 petroleum ether/acetone) $R_{\mathrm{f}}=0.34$; ${ }^{1} \mathrm{H}$ NMR $\left(360 \mathrm{MHz}, \mathrm{CD}_{3} \mathrm{CN}\right) \delta$ (two diastereomers) $1.04-1.06\left(4 \mathrm{H}, \mathrm{m}, 2 \mathrm{NCH}\left(\mathrm{CH}_{3}\right)_{2}\right)$, 1.14-1.18 (12H, m, $\left.2 \mathrm{NCH}\left(\mathrm{CH}_{3}\right)_{2}\right), 1.30,1.31$ $\left(9 \mathrm{H}, 2 \mathrm{~s}, \operatorname{SSC}\left(\mathrm{CH}_{3}\right)_{3}\right), 2.51-2.69(2 \mathrm{H}, \mathrm{m}$, $\left.\mathrm{OCH}_{2} \mathrm{CH}_{2} \mathrm{CN}\right), \quad 2.89-2.94 \quad(2 \mathrm{H}, \quad \mathrm{m}$, $\left.\mathrm{OCH}_{2} \mathrm{CH}_{2} \mathrm{~S}\right), \quad 3.37-3.44 \quad(2 \mathrm{H}, \quad \mathrm{m}$, $\left.\mathrm{OCH}_{2} \mathrm{CH}_{2} \mathrm{CN}\right), 3.58-3.66\left(2 \mathrm{H}, \mathrm{m}, 5^{\prime}, 5^{\prime \prime}\right)$, 3.76, $3.77\left(6 \mathrm{H}, 2 \mathrm{~s}, \mathrm{OCH}_{3}\right), 3.80-3.95(2 \mathrm{H}$, $\left.\mathrm{m}, \mathrm{OCH}_{2} \mathrm{CH}_{2} \mathrm{~S}\right), 4.06-4.12\left(2 \mathrm{H}, \mathrm{m}, 2^{\prime}, 4^{\prime}\right)$, 4.40-4.53 (1H, m, 3'), 5.20, $5.21(1 \mathrm{H}, 2 \mathrm{~d}, J$ $=8.1 \mathrm{~Hz}, 5), 5.85\left(1 \mathrm{H}, \mathrm{m}, 1^{\prime}\right), 6.86-6.90(4 \mathrm{H}$, $\mathrm{m}, \operatorname{Ar} H), 7.25-7.36(7 \mathrm{H}, \mathrm{m}, \mathrm{Ar} H), 7.42-7.47$ $(2 \mathrm{H}, \mathrm{m} \operatorname{Ar} H), 7.73,7.82(1 \mathrm{H}, 2 \mathrm{~d}, J=8.1 \mathrm{~Hz}$, 6). ${ }^{13} \mathrm{C}$ NMR (75 MHz, acetone- $\left.\mathrm{d}_{6}\right) \delta$ (two diastereomers) $20.96\left(\mathrm{NCH}\left(\mathrm{CH}_{3}\right)_{2}\right)$, 25.02$25.32\left(\mathrm{NCH}\left(\mathrm{CH}_{3}\right)_{2}\right), 29.14-30.68$ (acetone, $\left.\mathrm{SSC}\left(\mathrm{CH}_{3}\right)_{3}\right), 41.17\left(\mathrm{OCH}_{2} \mathrm{CH}_{2} \mathrm{~S}\right), 44.07$, $44.24\left(\mathrm{CH}_{2} \mathrm{CN}\right), 48.27\left(\mathrm{SSC}\left(\mathrm{CH}_{3}\right)_{3}\right), 55.68$ $\left(\mathrm{OCH}_{3}\right)$, 59.25-59.92 $\left(\mathrm{POCH}_{2}\right), 62.72,63.00$ (5'), 70.27, $70.41\left(\mathrm{OCH}_{2} \mathrm{CH}_{2} \mathrm{~S}\right), 71.30,71.48$ (3'), 82.11, $82.81\left(2^{\prime}\right), 83.14-83.41\left(4^{\prime}\right), 87.78$ (Ar), 89.04, $89.29\left(1^{\prime}\right), 102.53,102.59$ (5), 114.10 (Ar), 118.81, $118.96(\mathrm{CN}), 127.80$, $128.72,129.19,131.15,131.53,136.27$, $136.35,136.45$ (Ar), 140.65, 140.72 (6),
145.68, 145.75 (Ar), 151.21 (2), 159.80 (Ar), 163.37 (4). ${ }^{31} \mathrm{P}$ NMR $\left(202 \mathrm{MHz}, \mathrm{CD}_{3} \mathrm{CN}\right) \delta$ 147.44, 146.90. IR (KBr) v 3199, 3059, 2966, 2932, 2871, 2837, 2248, 1692, 1608, 1615, 1510, 1458, 1364, 1253, 1179, 1119, 1085, $1070,1035,980,828,810 \mathrm{~cm}^{-1}$. MS (FAB, 3-NBA) $m / z, 895\left(\mathrm{M}^{+}+1\right)$. Anal. Calcd for $\mathrm{C}_{45} \mathrm{H}_{59} \mathrm{~N}_{4} \mathrm{O}_{9} \mathrm{PS}_{2}$ : C, 60.38. H, 6.64. N, 6.26. Found: C, 60.59. H, 6.59. N, 5.95.

\section{Critical Parameters}

There are three critical parameters for the formation of intramolecular disulfide bonds in RNA. First, prior to oxidation the reducing agent used to remove the thiol protecting groups, DTT, must be entirely removed from sample. Second, the concentration of the RNA must be very low (1 to $4 \mu \mathrm{M}$ ) to avoid intermolecular cross-link formation. Third, for efficient cross-link formation the $\mathrm{pH}$ of the solution must be maintained between 8.0 and 8.4. At pH values $<8.0$ the concentration of thiolate ion will be reduced and the rate of cross-link formation will be reduced. However, prolonged exposure of the RNA to $\mathrm{pH}$ values $>8.4$ may lead to degradation.

\section{Troubleshooting}

See Table 5.4.1 for discussion of common problems encountered with these procedures and methods to identify, solve, and avoid them.

\section{Anticipated Results}

The authors have achieved $100 \%$ conversion of tert-butyl disulfide-protected tRNAs to intramolecularly disulfide-cross-linked tRNAs at three different sites of disulfide incorporation. Similar results should be obtained for thiols positioned at proximal locations either in a folded tertiary structure or within secondary structure.

The solid-phase synthesis of tRNAs containing the thiol-modified nucleosides described here results in yields of $0.5 \mathrm{mg}$ tRNA after purification to single-nucleotide resolution. Each thiol-modified nucleoside is incorporated into the RNA oligomer as efficiently as commercially available phosphoramidites.

\section{Time Considerations}

Conversion of the tert-butyl disulfide-protected RNA to disulfide-cross-linked RNA takes 36 to $48 \mathrm{hr}$; both the reduction of the tert-butyl disulfide protecting groups and the air oxidation can be done as overnight reactions. To ensure complete reduction of the tert-butyl disulfide protecting groups the 
Table 5.4.1 Troubleshooting Guide for Disulfide Cross-Linking

\begin{tabular}{|c|c|c|}
\hline Problem & Possible causes & Solution \\
\hline \multirow[t]{7}{*}{$\begin{array}{l}\text { RNA does not cross-link or does not } \\
\text { cross-link quantitatively }\end{array}$} & $\begin{array}{l}\text { Protecting groups were not completely } \\
\text { reduced }\end{array}$ & $\begin{array}{l}\text { Add more DTT and/or incubate longer. } \\
\text { After DTT removal, thiols on the RNA } \\
\text { can be quantified using the fluorescent } \\
\text { assay. }\end{array}$ \\
\hline & $\begin{array}{l}\text { DTT was not completely removed } \\
\text { before oxidation commenced }\end{array}$ & $\begin{array}{l}\text { Dialyze at a slower rate; use more } \\
\text { buffer; monitor the dialysate with the } \\
\text { fluorescence assay to determine when } \\
\text { all DTT has been removed }\end{array}$ \\
\hline & $\mathrm{pH}$ of the reaction was $<8.0$ & Adjust $\mathrm{pH}$ to 8.0 \\
\hline & $\begin{array}{l}\text { RNA was not properly folded before } \\
\text { oxidation commenced }\end{array}$ & Fold the RNA \\
\hline & RNA was not pure & $\begin{array}{l}\text { Repurify the starting thiol-modified } \\
\text { RNA }\end{array}$ \\
\hline & $\begin{array}{l}\text { Thiols are not positioned close enough } \\
\text { to react }\end{array}$ & $\begin{array}{l}\text { Select alternate positions for } \\
\text { modification }\end{array}$ \\
\hline & $\begin{array}{l}\text { Resulting cross-linked RNA would be } \\
\text { a strained, high-energy structure }\end{array}$ & $\begin{array}{l}\text { Select alternate positions for } \\
\text { modification }\end{array}$ \\
\hline \multirow[t]{4}{*}{$\begin{array}{l}\text { Modified nucleosides incorporate } \\
\text { poorly during RNA synthesis }\end{array}$} & $\begin{array}{l}\text { Moisture was present in } \\
\text { phosphoramidite }\end{array}$ & $\begin{array}{l}\text { Dry amidites by evaporation from } \\
\text { freshly distilled } \mathrm{CH}_{3} \mathrm{CN} \text { several times }\end{array}$ \\
\hline & & Handle amidites under $\mathrm{Ar}$ \\
\hline & & Repurify the phosphoramidite \\
\hline & & $\begin{array}{l}\text { Dilute the amidite with } \mathrm{CH}_{3} \mathrm{CN} \\
\text { immediately before coupling instead } \\
\text { of at the beginning of the synthesis }\end{array}$ \\
\hline
\end{tabular}

RNA should be incubated with DTT for $\geq 12$ hr, while $>14 \mathrm{hr}$ appears unnecessary. The slow rate of dialysis $(5 \mathrm{~mL} / \mathrm{min})$, using $3 \mathrm{~L}$ of buffer over $10 \mathrm{hr}$, ensures that the DTT is completely removed and that the buffer exchange into the lower-salt buffer is complete. Cross-link formation between thiols positioned at locations that are proximal in the folded RNA generally occurs in $<12 \mathrm{hr}$. It has taken up to $48 \mathrm{hr}$ for completion of some cross-linking reactions; in such cases the $\mathrm{pH}$ is monitored periodically and adjusted as necessary, and water is also added to compensate for evaporation.

Synthesis and purification of thiol-modified tRNA takes between 1 and 2 weeks depending on the amount of RNA to be purified before proceeding with the cross-linking reaction. This includes 1 day to synthesize the necessary phosphoramidites before commencing the solid-phase synthesis.

\section{Literature Cited}

Allerson, C.R., Chen, S.L., and Verdine, G.L. 1997. A chemical method for site-specific modification of RNA: The convertible nucleoside approach. J. Am. Chem. Soc. 119:7423-7433.

Allerson, C.R. and Verdine, G.L. 1995. Synthesis and biochemical evaluation of RNA containing an intrahelical disulfide crosslink. Chem. Biol. 2:667-675.

Breslauer, K.J., Frank, R., Blöcker, H., and Markey, L.A. 1986. Predicting DNA duplex stability from the base sequence. Proc. Natl. Acad. Sci. U.S.A. 83:3746-3750.

Cohen, S.B. and Cech, T.R. 1997. Dynamics of thermal motions within a large catalytic RNA investigated by crosslinking with thiol-disulfide interchange. J. Am. Chem. Soc. 119:6259-6268.

Douglas, M.E., Beijer, B., and Sproat, B.S. 1994. An approach towards thiol mediated labelling in the minor groove of oligonucleotides. Bioorg. Med. Chem. Lett. 4:995-1000.

Earnshaw, D.J., Masquida, B., Müller, S., Sigurdsson, S.T., Eckstein, F., Westhof, E., and Gait, M.J. 1997. Inter-domain cross-linking and molecular modelling of the hairpin ribozyme. $J$. Mol. Biol. 274:197-212.
Methods for Cross-Linking Nucleic Acids 
Gait, M.J., Pritchard, C., and Slim, G. 1991. Oligoribonucleotide synthesis. In Oligonucleotides and Analogues. A Practical Approach (F. Eckstein, ed.) pp. 25-48. Oxford University Press, Oxford.

Glick, G.D. 1991. Synthesis of a conformationally restricted DNA hairpin. J. Org. Chem. 56:67466747.

Glick, G.D. 1998. Design, synthesis, and analysis of conformationally restricted nucleic acids. Biopolymers 48:83-96.

Goodwin, J.T., Osborne, S.E., Scholle, E.J., and Glick, G.D. 1996. Design, synthesis, and analysis of yeast tRNA ${ }^{\text {Phe analogs possessing intra- }}$ and interhelical disulfide cross-links. J. Am. Chem. Soc. 118:5207-5214.

Goodwin, J.T., Stanick, W.A., and Glick, G.D. 1994. Improved solid-phase synthesis of long oligoribonucleotides: Application to tRNA ${ }^{\text {Phe }}$ and tRNA $^{\text {Gly }}$. J. Org. Chem. 59:7941-7943.

Gundlach, C.W. IV, Ryder, T.R., and Glick, G.D. 1997. Synthesis of guanosine analogs bearing pendant alkylthiol tethers. Tetrahedron Lett. 38:4039-4042.

Maglott, E.J. and Glick, G.D. 1998. Probing structural elements in RNA using engineered disulfide bonds. Nucl. Acids Res. 26:1301-1308.

Manoharan, M., Johnson, L.K., Tivel, K.L., Springer, R.H., and Cook, P.D. 1993. Introduction of a lipophilic thioether tether in the minor groove of nucleic acids for antisense applications. Bioorg. Med. Chem. Lett. 3:2765-2770.

Parvari, R., Pecht, I., and Soreq, H. 1983. A microfluorimetric assay for cholinesterases, suitable for multiple kinetic determinations of picomoles of released thiocholine. Anal. Biochem. 133:450-456.
Schaller, H., Weimann, G., Lerch, B., and Khorana, H.G. 1963. Studies on polynucleotides. XXIV. The stepwise synthesis of specific deoxyribopolynucleotides (4). Protected derivatives of deoxyribonucleosides and new syntheses of deoxyribonucleoside-3' phosphates. J. Am. Chem. Soc. 85:3821-3827.

Sigurdsson, S.T., Tuschl, T., and Eckstein, F. 1995. Probing RNA tertiary structure: Interhelical crosslinking of the hammerhead ribozyme. $R N A$ 1:575-583.

Sigurdsson, S.T. and Eckstein, F. 1996. Isolation of oligoribonucleotides containing intramolecular cross-links. Anal. Biochem. 235:241-242.

Sproat, B.S. and Lamond, A.I. 1991. 2'-O-Methyloligoribonucleotides: Synthesis and application. In Oligonucleotides and Analogues. A Practical Approach (F. Eckstein, ed.) pp. 49-86. Oxford University Press, Oxford.

Sproat, B.S., Iribarren, A., Beijer, B., Pieles, U., and Lamond, A.I. 1991. 2'-O-alkyloligoribonucleotides: Synthesis and applications in studying RNA splicing. Nucleosides Nucleotides 10:25-36.

Sun, S., Tang, X.-Q., Merchant, A., Anjaneyulu, P.S.R., and Piccirilli, J.A. 1996. Efficient synthesis of 5-(thioalkyl)uridines via ring opening of $\alpha$-ureidomethylene thiolactones. J. Org. Chem. 61:5708-5709.

Wünsch, E., Moroder, L., and Romani, S. 1982. 1-(tert-Butylthio)-1,2-hydrazinedicarboxoylic acid derivatives. New reagents for the introduction of the $S$-tert-butylthio group into cysteine and cysteine derivatives. Hoppe-Seylers $Z$. Physiol. Chem. 363:1461-1464.

Contributed by Emily J. Maglott and

Gary D. Glick

University of Michigan

Ann Arbor, Michigan
Engineering

Disulfide

Cross-Links in

RNA via Air Oxidation 